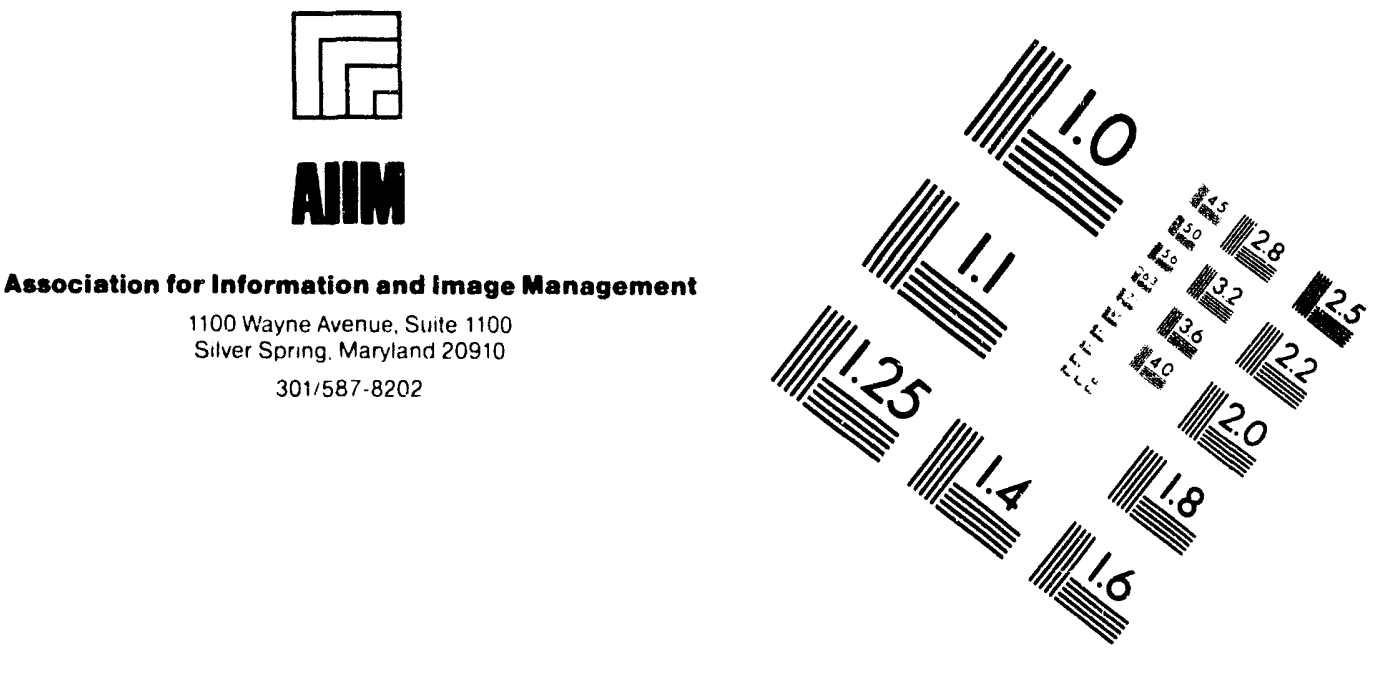

Centimeter

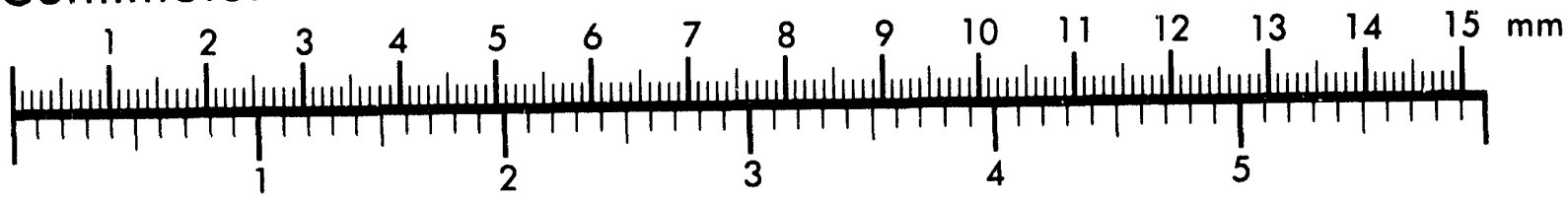
Inches
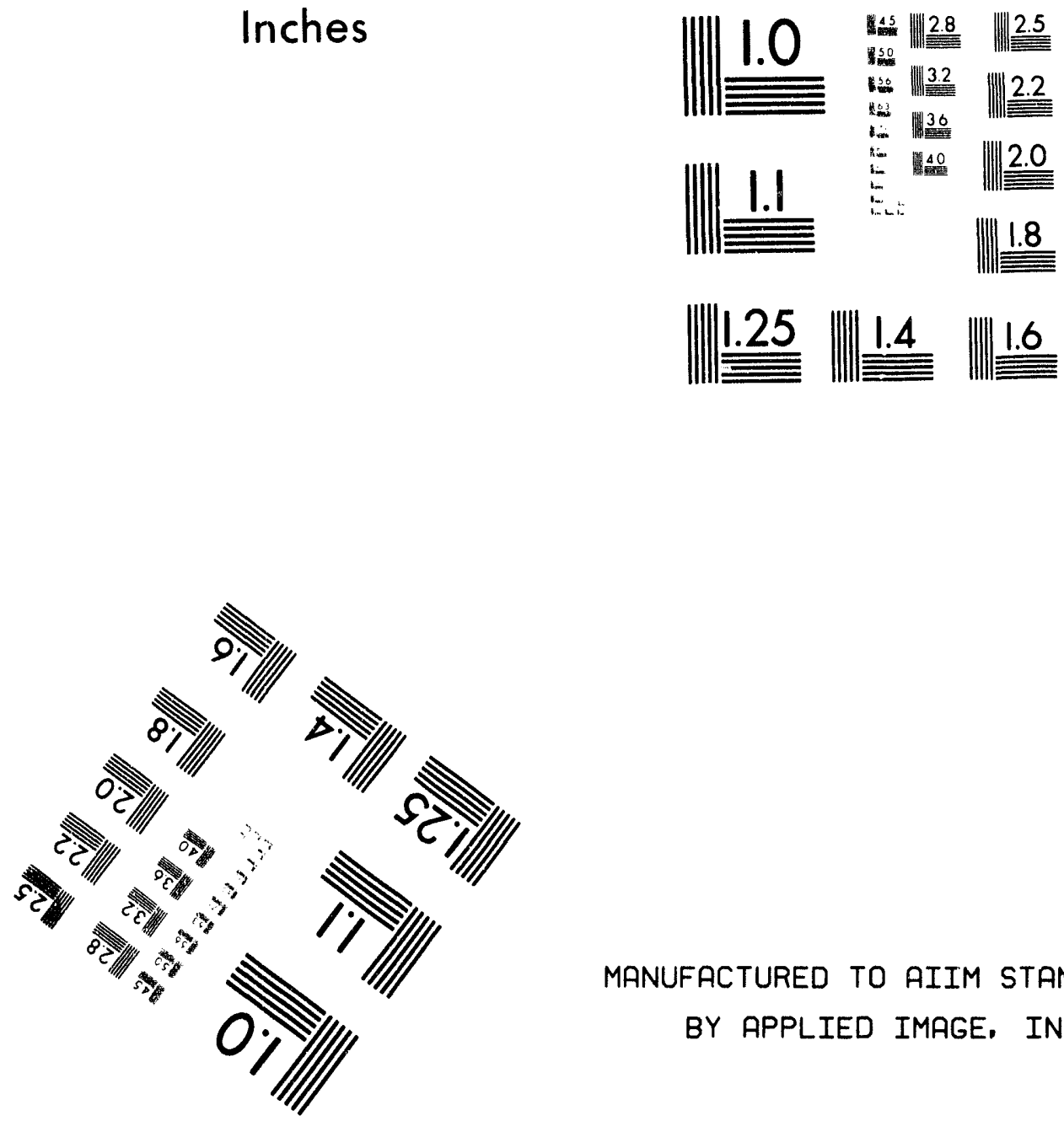

MANUFACTURED TO AIIM STANDARDS

BY APPLIED IMAGE, INC.

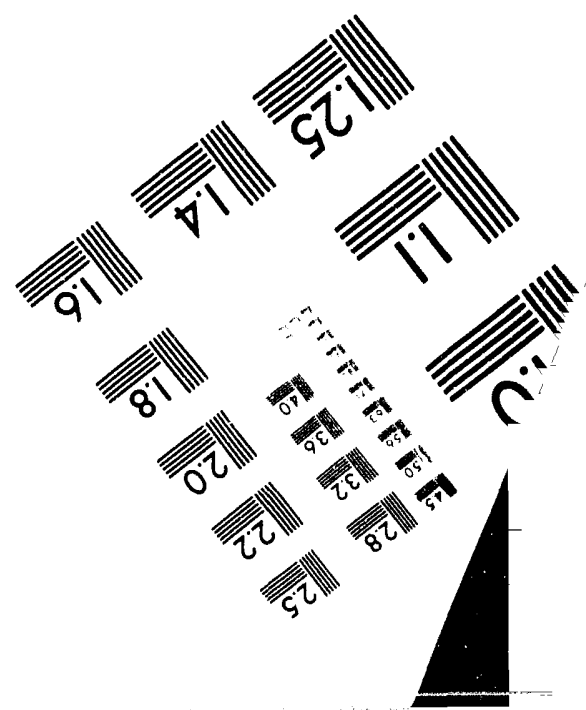



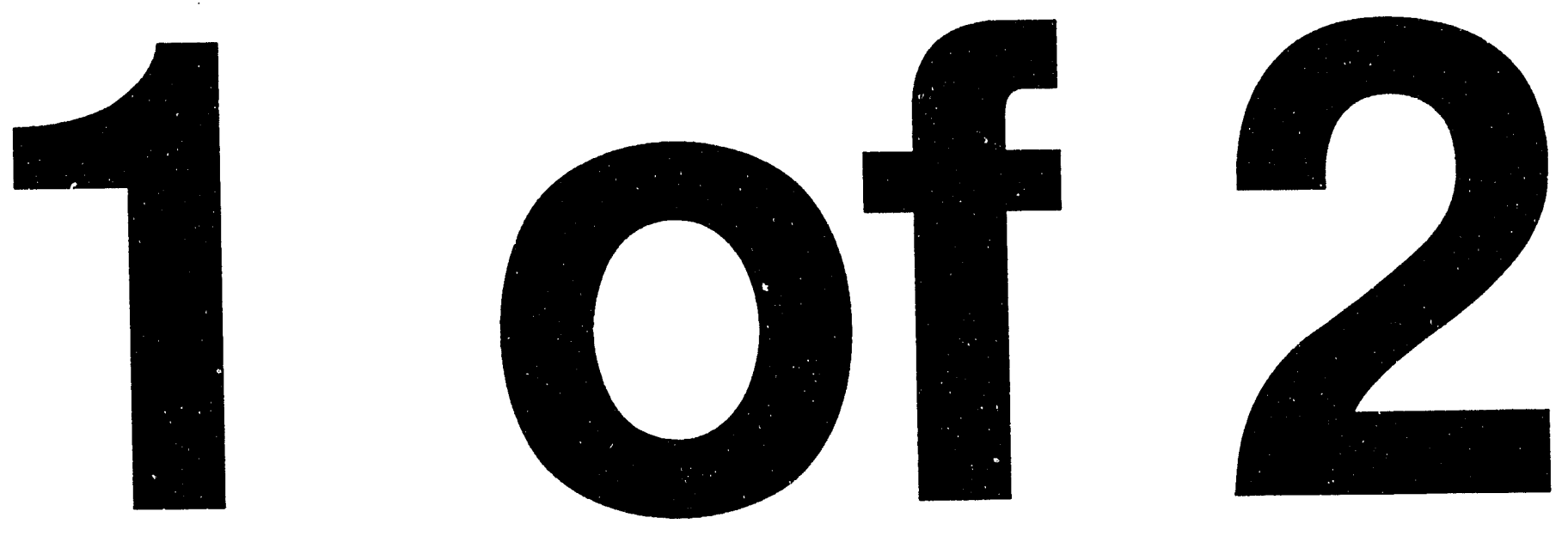


\title{
Economics of a Small-Volume Low-Level Radioactive Waste Disposal Facility
}

\author{
DISCLAIMER
}

This report was prepared as an account of work sponsored by an agency of the United States Government. Neither the United States Government nor any agency thereof, nor any of their employees, makes any warranty, express or implied, or assumes any legal liability or responsibility for the accuracy, completeness, or usefulness of any information, apparatus, product, or process disclosed, or represents that its use would not infringe privately owned rights. Reference herein to any specific commercial product, process, or service by trade name, trademark, manufacturer, or otherwise does not necessarily constitute or imply its endorsement, recommendation, or favoring by the United States Government or any agency thereof. The views and opinions of authors expressed herein do not necessarily state or reflect those of the United States Government or any agency thereof.

\section{April 1993}

\section{Idaho National Engineering Laboratory EG\&G Idaho, Inc. National Low-Level Waste Management Program Idaho Falls, Idaho 83415}

Prepared by Dames \& Moore

for the U.S. Department of Energy

Programs Group

DOE Idaho Field Office

under DOE Contract No. DE-AC07-76ID01570 


\begin{abstract}
This report was prepared by the U.S. Department of Energy National Low-Level Waste Management Program to present the results of a life-cycle cost analysis of a low-level radioactive waste disposal facility, including all support facilities, beginning in the pre-operational phase and continuing through post-closure care. The disposal technology selected for this report is earthcovered concrete vaults, which use reinforced concrete vaults constructed above grade and an earth cover constructed at the end of the operational period for permanent closure. The report develops a design, cost estimate, and schedule for the base case and eight alternative scenarios involving changes in total disposal capacity, operating life, annual disposal rate, source of financing and long-term interest rates. The purpose of this analysis of alternatives is to determine the sensitivity of cost to changes in key analytical or technical parameters, thereby evaluating the influence of a broad range of conditions. The total estimated cost of each alternative is estimated and a unit disposal charge is developed.
\end{abstract}




\section{SUMMARY}

The Radioactive Waste Policy Amendments Act of 1985 requires the Department of Energy to provide technical assistance to compact regions, host states, and non-member states for the siting, design, and operation of a radioactive waste disposal facility. This report presents the result of a conceptual design and life-cycle cost analysis prepared for a low-level radioactive waste disposal facility, including a base case and alternatives. Earth-covered concrete vaults were selected for the disposal technology and a facility was designed to support operations at the site, inciuding aceess roads, buildings for personnel and equipment, a waste storage facility, and a fenced disposal area surrounded by an exclusion area.

The result of the life-cycle cost analysis for the base case conditions, expressed in terms of a unit disposal charge, is $\$ 223.99$ per cubic foot. The unit disposal charges for the base case and each of the alternate cases considered for the sensitivity analysis are summarized in the following chart. The unit disposal charge for the base case, $\$ 223.99$ per cubic foot, is indicated at the left, and this value is the reference value used to evaluate the results of the sensitivity analysis. Two alternate values were evaluated for each variable chosen for analysis. The results are presented to the right of the base case for comparison.

The base case analysis showed that costs incurred in the pre-operations and operations phase of the disposal facility life contributed almost equally to the unit disposal charge and together. constituted approximately $94 \%$ of the total unit disposal charge. Further analysis showed the total pre-operations and operations phase costs to be relatively fixed over the range of conditions evaluated for this study. Labor for receiving and emplacing waste was the principal variable cost

\section{Unit Disposal Charge Sensitivity Analysis Results}

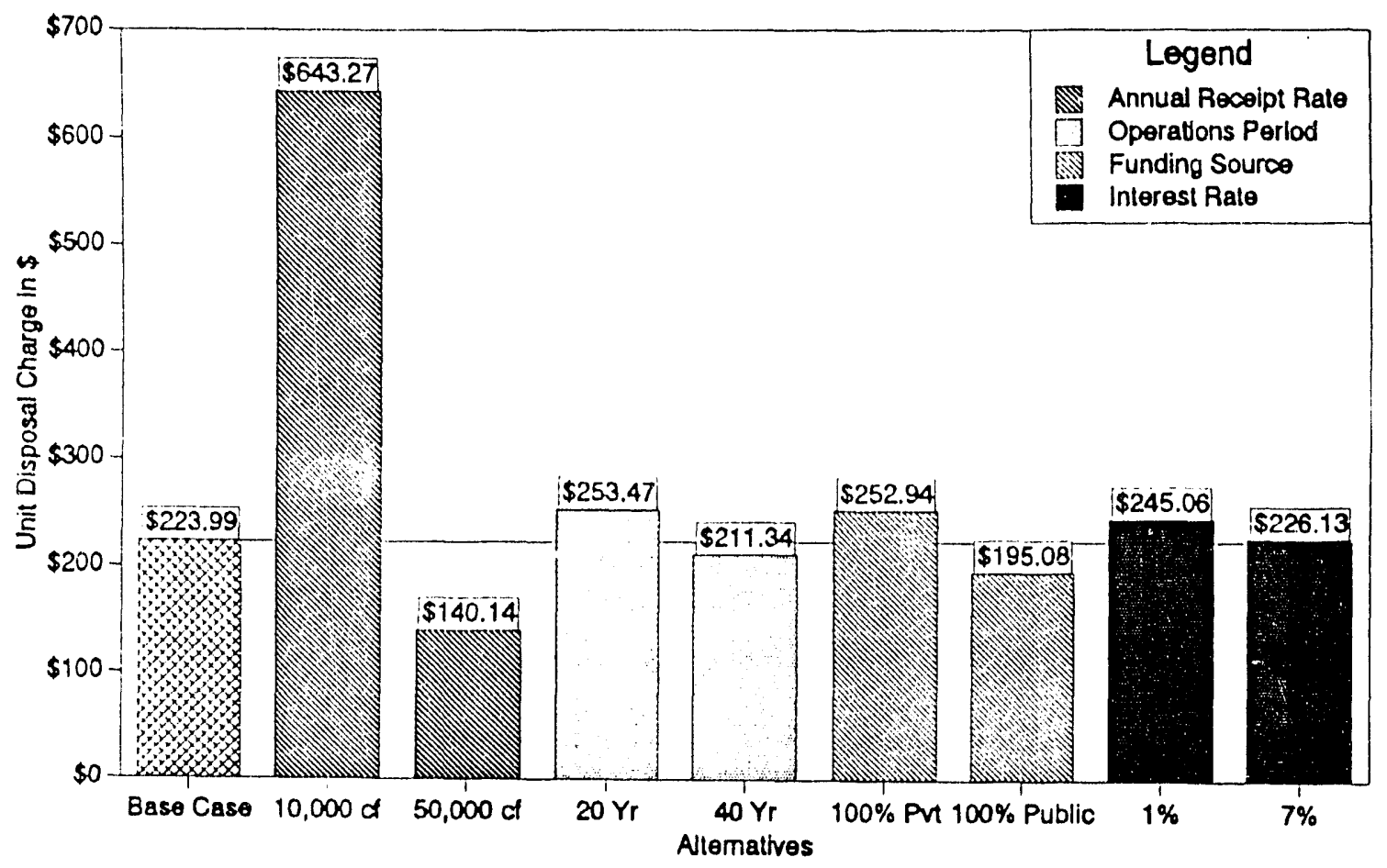


in the operations phase and these costs constituted only $3.3 \%$ of total operations costs. Engineering and construction costs for the disposal cells themselves were the only variable costs in the pre-operations phase and these constituted only $28 \%$ of total pre-operations costs. Thus, total costs of the facility and its operation are relatively independent of facility size.

The unit disposal charge was found to be more sensitive to changes in the waste receipt rate than the other lactors shown by the preceding chart. The total costs for the operations phase were not changed greatly hy increasing or decreasing the annual waste receipt rate. However, larger total volumes of waste aceepted for disposal provide a broader basis over which to distribute total facility life-cycle costs. Thus, the unit disposal charge is increased when the annual receipt rate is decreased, and the charge is decreased when the annual receipt rate is increased.

The second most significant parameter measured in the sensitivity analysis is the source of financing. This impact is attributable to several causes, including higher rates of interest associated with private debt, the impact of taxes on private operators, and the use of a mix of equity capital and debt for the private financing with a higher return required on capital than debt. Consequently, higher participation by private industry tends to increase the cost, if all other factors remain the same.

The sensitivity of the unit disposal charge to the operating life was measured as the third most significant variable. As was the ease with variation in the waste receipt rate, this sensitivity is attributed mostly to the influence of operating life on total disposed volume. The contribution of a change in the operating life, and the associated contribution of this change to the cost of operations, was moderated because total waste volume varied directly with operating life.

The least impact was attributed to the variation in the interest rate. This result is in contrast to that obtained under a change in ownership structure because of two forces that act in unison, but impact different ends of the expenditure profile in opposite ways and consequently tend to cancel out. For example, decreases in the interest rate for borrowed money tend to decrease the cost of the pre-operations phase because this phase is financed (to some degree) with borrowed money. However, decreases in the same interest rate tend to increase the cost of the closure and post-closure phase because this phase is financed with invested funds. In total, decreases in the interest rate tend to increase the unit disposal charge primarily because there is less investment income available to help fund the closure and post-closure periods.

The results indicate that the unit disposal charge is not particularly sensitive to an increase in interest rate (and henee the discount rate). However, the unit disposal charge was more sensitive to a decrease in interest rate (and hence the discount rate).

This economic report indicates that the lowest unit disposal charge is achieved with a large publicly financed facility. The largest cost components in terms of their contribution to the wit disposal eharge are pre-operational and operational activities. 


\section{CONTENTS}

ABSTRACT $\ldots \ldots \ldots \ldots \ldots \ldots \ldots \ldots \ldots \ldots \ldots \ldots \ldots \ldots \ldots \ldots \ldots \ldots \ldots \ldots$

SUMMARY $\ldots \ldots \ldots \ldots \ldots \ldots \ldots \ldots \ldots \ldots \ldots \ldots \ldots \ldots \ldots \ldots \ldots$

ACRONYMS $\ldots \ldots \ldots \ldots \ldots \ldots \ldots \ldots \ldots \ldots \ldots \ldots \ldots \ldots \ldots \ldots \ldots \ldots \ldots$

CHEMICAL ABBREVIATIONS $\ldots \ldots \ldots \ldots \ldots \ldots \ldots \ldots \ldots \ldots \ldots \ldots \ldots \ldots \ldots \ldots$

1. INTRODUCTION $\ldots \ldots \ldots \ldots \ldots \ldots \ldots \ldots \ldots \ldots \ldots \ldots \ldots \ldots \ldots \ldots \ldots \ldots$

1.1 Background $\ldots \ldots \ldots \ldots \ldots \ldots \ldots \ldots \ldots \ldots \ldots \ldots \ldots \ldots \ldots \ldots \ldots$

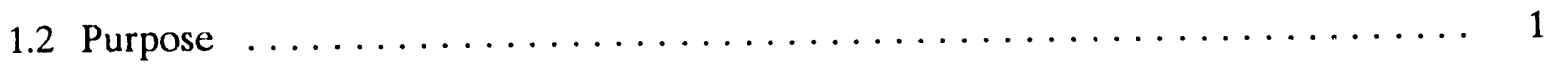

1.3 Report Organization $\ldots \ldots \ldots \ldots \ldots \ldots \ldots \ldots \ldots \ldots \ldots \ldots \ldots \ldots \ldots$

2. GENERAL ASSUMPTIONS $\ldots \ldots \ldots \ldots \ldots \ldots \ldots \ldots \ldots \ldots \ldots \ldots \ldots \ldots \ldots$

2.1 Design Assumptions $\ldots \ldots \ldots \ldots \ldots \ldots \ldots \ldots \ldots \ldots \ldots \ldots \ldots \ldots \ldots \ldots$

2.2 Operating Assumptions $\ldots \ldots \ldots \ldots \ldots \ldots \ldots \ldots \ldots \ldots \ldots \ldots \ldots \ldots \ldots \ldots$

2.3 Cost Estimating Assumptions $\ldots \ldots \ldots \ldots \ldots \ldots \ldots \ldots \ldots \ldots \ldots \ldots \ldots \ldots$

3. ESTIMATED LIFE CYCLE COSTS $\ldots \ldots \ldots \ldots \ldots \ldots \ldots \ldots \ldots \ldots \ldots \ldots$

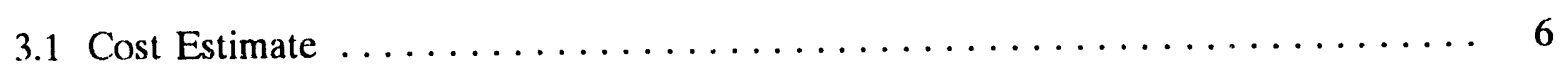

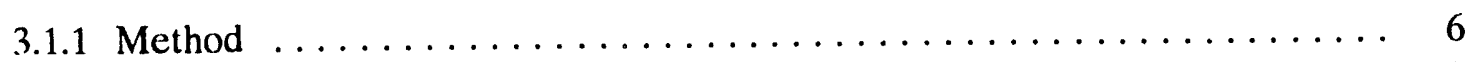

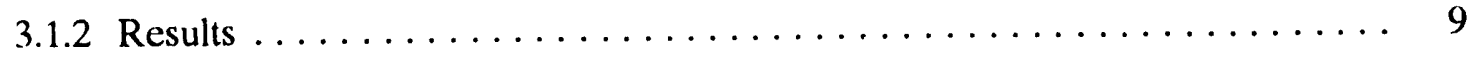

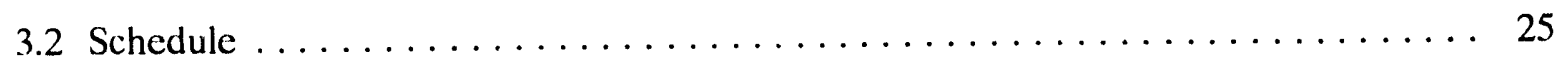

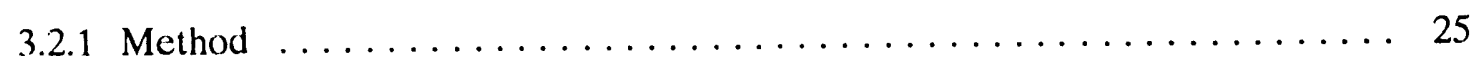

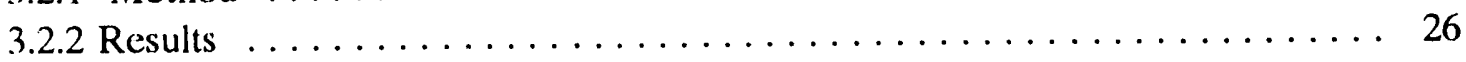

3.3 Unit Disposal Charge $\ldots \ldots \ldots \ldots \ldots \ldots \ldots \ldots \ldots \ldots \ldots \ldots \ldots \ldots \ldots \ldots \ldots$

3.3.1 Method . . . . . . . . . . . . . . . . . . 31

3.3.2 Results-Unit Disposal Cost Analysis, Base Case . . . . . . . . . . 39

3.4 Sensitivity Analysis $\ldots \ldots \ldots \ldots \ldots \ldots \ldots \ldots \ldots \ldots \ldots \ldots \ldots \ldots \ldots \ldots$

3.4.1 Variation in Disposal Facility Waste Reccipt Rate ............ 4.3 
3.4 .2 Variation in Operating Life $\ldots \ldots \ldots \ldots \ldots \ldots \ldots \ldots \ldots \ldots \ldots \ldots$

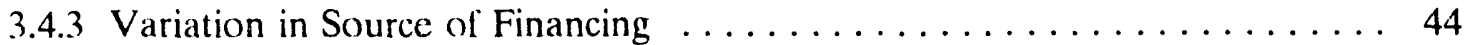

3.4 .4 Variation in Interest Rates ................... 47

4. SUMMARY ............................. 49

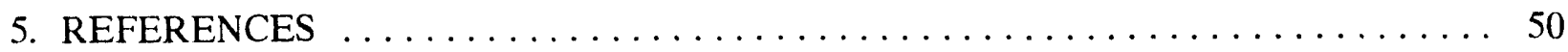

Appendix A-Site, Facility, and Operating Description $\ldots \ldots \ldots \ldots \ldots \ldots \ldots \ldots \ldots$ A

Appendix B-Dose Assessment $\ldots \ldots \ldots \ldots \ldots \ldots \ldots \ldots \ldots \ldots \ldots \ldots \ldots \ldots \ldots \ldots$

Appendix $\mathrm{C}-$ Cell Sizing Calculations $\ldots \ldots \ldots \ldots \ldots \ldots \ldots \ldots \ldots \ldots \ldots \ldots \ldots \ldots \ldots \ldots$

Appendix $\mathrm{D}-$ Contingency Analysis $\ldots \ldots \ldots \ldots \ldots \ldots \ldots \ldots \ldots \ldots \ldots \ldots \ldots \ldots \ldots \ldots \ldots \ldots \ldots$

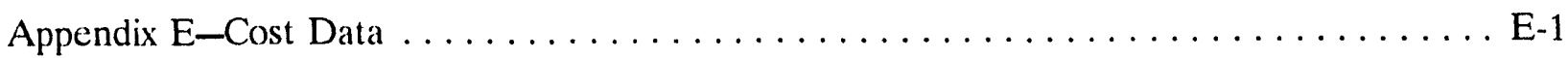

\section{FIGURES}

3-1. Project summary schedule. . . . . . . . . . . . . . . . . . . 27

3-2. Pre-operations schedule. $\ldots \ldots \ldots \ldots \ldots \ldots \ldots \ldots \ldots \ldots \ldots \ldots \ldots \ldots \ldots \ldots \ldots$

3-3. Operations schedule. $\ldots \ldots \ldots \ldots \ldots \ldots \ldots \ldots \ldots \ldots \ldots \ldots \ldots \ldots \ldots \ldots \ldots$

3-4. Closure and post-closure schedule. . . . . . . . . . . . . . . . . 30

\section{TABLES}

2-1. Technical and analytical parameters. $\ldots \ldots \ldots \ldots \ldots \ldots \ldots \ldots \ldots \ldots \ldots \ldots$

3-1. Pre-operating cost summary $(\$) \ldots \ldots \ldots \ldots \ldots \ldots \ldots \ldots \ldots \ldots \ldots \ldots \ldots$

3-2. Management support labor unit cost. $\ldots \ldots \ldots \ldots \ldots \ldots \ldots \ldots \ldots \ldots \ldots \ldots$

3-3. Pre-operations one-time sampling program costs (Year 1$) \ldots \ldots \ldots \ldots \ldots \ldots \ldots \ldots$

3-4. Baseline environmental monitoring program - pre-operations period (one year). . . . . 13

3-5. Pre-operating staff requirements. $\ldots \ldots \ldots \ldots \ldots \ldots \ldots \ldots \ldots \ldots \ldots \ldots \ldots \ldots \ldots$

3-6. Operating cost summary. $\ldots \ldots \ldots \ldots \ldots \ldots \ldots \ldots \ldots \ldots \ldots \ldots \ldots \ldots \ldots \ldots$ 
3-7. Operating staff requirements site management. $\ldots \ldots \ldots \ldots \ldots \ldots \ldots$

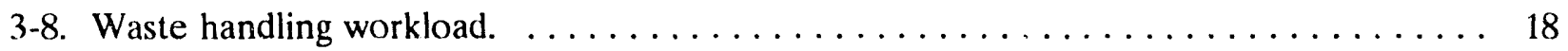

3-9. Waste handling staff requirements-temporary contract crew. . . . . . . . . 19

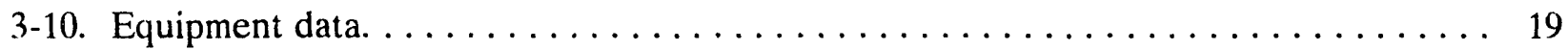

3-11. Environmental monitoring costs - operating period and closure period. . . . . . 20

3-12. Closure cost summary $(\$) . \ldots \ldots \ldots \ldots \ldots \ldots \ldots \ldots \ldots \ldots \ldots \ldots \ldots \ldots \ldots$

3-13. Site management staff requirements. $\ldots \ldots \ldots \ldots \ldots \ldots \ldots \ldots \ldots \ldots \ldots \ldots$

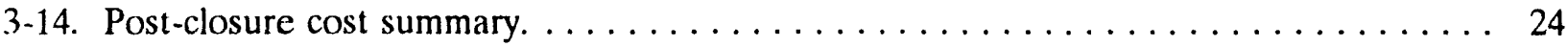

3-15. Site management staff requirements. $\ldots \ldots \ldots \ldots \ldots \ldots \ldots \ldots \ldots \ldots \ldots \ldots \ldots$

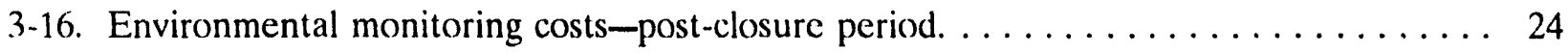

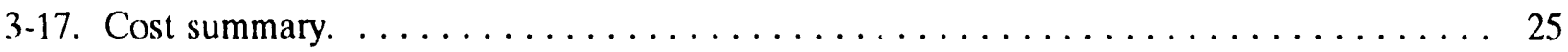

3-18. Examples of alternate investments. . . . . . . . . . . . . . . . 29

3-19. Key financial parameters - base case. $\ldots \ldots \ldots \ldots \ldots \ldots \ldots \ldots \ldots \ldots$

3-20. Unit disposal charge-base case. $\ldots \ldots \ldots \ldots \ldots \ldots \ldots \ldots \ldots \ldots \ldots \ldots$

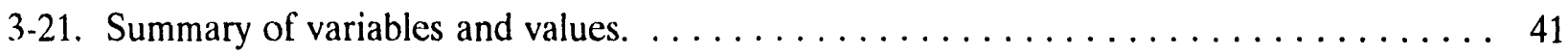

3-22. Base case and alternate case specific parameters (shaded blocks indicate changes from

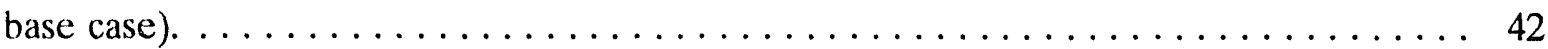

3-23. Unit disposal charge $-10,000 \mathrm{ft}^{3}$ per year. $\ldots \ldots \ldots \ldots \ldots \ldots \ldots \ldots \ldots$

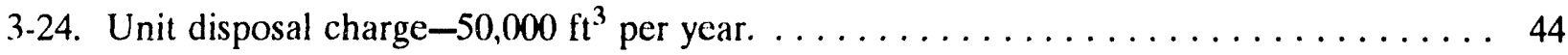

3-25. Unit disposal charge-20-Year operating life. $\ldots \ldots \ldots \ldots \ldots \ldots \ldots \ldots$

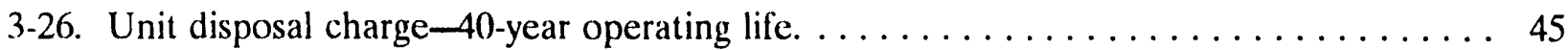

3-27. Unit disposal charge $-100 \%$ private financing. $\ldots \ldots \ldots \ldots \ldots \ldots \ldots$

3-28. Unit disposal charge $-100 \%$ public financing. $\ldots \ldots \ldots \ldots \ldots \ldots \ldots \ldots$

3-29. Unit disposal charge-1\% per year public agency debt rate. $\ldots \ldots \ldots \ldots \ldots$ 
3-30. Unit disposal charge $-7 \%$ per year public agency debt rate. $\ldots \ldots \ldots \ldots \ldots$

4-1. Unit disposal charge summary $\left(\$ / \mathrm{ft}^{3}\right) \ldots \ldots \ldots \ldots \ldots \ldots \ldots \ldots \ldots \ldots \ldots$ 


\section{ACRONYMS}

ACI American Concrete Institute

ANSI American National Standards Institute Document

ASCE American Society of Civil Engineers

CDR conceptual design report

CFR Code of Federal Regulations

DOE U.S. Department of Energy

LLW low-level radioactive waste

NRC U.S. Nuclear Regulatory Commission

TAL target analyte list

TCL target compound list

TLD thermoluminescent dosimeter

TOC total organic carbon

TOX total organic halogens

WBS work breakdown structure 


\section{CHEMICAL ABBREVIATIONS}

\begin{tabular}{|c|c|c|c|}
\hline Am-241 & americium-241 & $\mathrm{Mg}^{++}$ & magnesium ion \\
\hline C-14 & carbon-14 & $\mathrm{Na}^{+}$ & sodium ion \\
\hline Cs-137 & cesium-137 & & \\
\hline $\mathrm{H}-3$ & hydrogen-3 (tritium) & & \\
\hline I-125/129/131 & iodine-125/129/131 & & \\
\hline $\mathrm{Kr}-85$ & krypton-85 & & \\
\hline $\mathrm{Ni}-63$ & nickel-63 & & \\
\hline Np-237 & neptunium-237 & & \\
\hline Pu-238/239/240 & plutonium-238/239/240 & & \\
\hline $\mathrm{Ra}-226 / 288$ & raciium-226/288 & & \\
\hline Sr-90 & strontium-90 & & \\
\hline Tc-99 & technetium-99 & & \\
\hline U-234/235/238 & uranium-234/235/238 & & \\
\hline $\mathrm{CN}^{-}$ & cyanide ion & & \\
\hline $\mathrm{CO}_{3}=$ & carbonate ion & & \\
\hline $\mathrm{NO}_{3}=$ & nitrate ion & & \\
\hline $\mathrm{NO}_{2}=$ & nitrite ion & & \\
\hline $\mathrm{PO}_{4}^{-3}$ & phosphate ion & & \\
\hline $\mathrm{SO}_{4}=$ & sulphate ion & & \\
\hline $\mathrm{Ca}^{+}$ & calcium ion & & \\
\hline $\mathrm{Cl}^{-}$ & chlorine ion & & \\
\hline $\mathrm{K}^{+}$ & potassium ion & & \\
\hline
\end{tabular}




\section{Economics of a Small-Volume Low-Level Radioactive Waste Disposal Facility}

\section{INTRODUCTION}

\subsection{Background}

The Low-Level Radioactive Waste Policy Amendments Act of 1985 (Public Law 99-240) requires the Department of Energy (DOE) to provide technical assistance to states and compact regions in establishing and fulfilling their new low-level radioactive waste (LLW) capacity responsibilities under the Act. The objective of this report is to present the results of a cost study for a LLW disposal facility receiving a relatively small volume of waste. The earth-covered concrete vault technology used in this report combines aspects of two technologies: above-ground vault and earth-mounded concrete bunker, examined in the conceptual design report titled, Alternative Concepts for Radioactive Waste Disposal, published in June 1987 (CDR). ${ }^{1}$

\subsection{Purpose}

The purpose of this report is to evaluate the life-cycle costs associated with the planning, construction, operation, closure, and post-closure care of a small-volume LLW disposal facility using an earth-covered concrete vault technology. The life-cycle costs are developed for the four periods in the facility life: pre-operatiors (planning, siting, licensing, construction); operation (waste receipt and storage); closure (site closure and five-year monitoring); and post-closure (institutional care and monitoring for 100 years). It is anticipated that the information presented in this report will provide state developers with technical and financial data that would be helpful in the development of specific designs and concepts for site specific facilities.

The design developed for this study is not site specific and consequently, generic assumptions were used to represent site characteristics and to allow development of a suitable design. Every effort was made to develop assumptions that were both reasonable and defensible; these assumptions are documented in Chapter 2 and should be reviewed for applicability by anyone seeking to use the data in this report. The approach used to develop the design and to conduct the economic analyses used in this report employs a base case scenario and sensitivity analysis of four primary technical and analytical parameters. The base values are neither preferred nor recommended, but were selected to represent a point of reference. Each of the four major parameters selected for variation was ranged both above and helow the value used in the base case. The purpose of this approach is to demonstrate the impact on cost of variations in selected project parameters, thereby making the report more useful to a broader constituency of readers.

\subsection{Report Organization}

This report is organized into five chapters. The lirst chapter is the introduction, which presents the background, purpose, and organization of the report. The second chapter presents the general assumptions used to develop the design, operating plan, and cost estimate, including the base case parameters and the alternatives considered in the sensitivity analysis. Chapter 3 presents the costs associated with each phase of activity, including the results of the sensitivity 
analysis. Chapter 4 summarizes the results of the report and is followed by a list of references (Section 5) and appendices containing supporting material. Appendix A describes the site and disposal faciiity. This appendix has three sections, covering the site, support facilities and disposal systems, and disposal operations. 


\section{GENERAL ASSUMPTIONS}

This chapter presents the assumptions developed for the design, operation, and cost evaluations prepared for this report. These assumptions are presented separately in each of the three categories, but significant interdependencies exist and, consequently, assumptions relating to one category, such as operation, can influence results in another area such as cost. Design and operating assumptions are presented for only the base case. The cost assumptions present the range of technical and analytical parameters used for the sensitivity analysis.

\subsection{Design Assumptions}

- A single site will be selected for detailed characterizatic n.

- The performance of the earth-covered concrete vaults meets the performance objectives established in Subpart C of 10 CFR 61. No actual performance assessment was prepared as part of this study to demonstrate compliance. ${ }^{\text {a }}$

- Structural design criteria are summarized in Table A-2 of Appendix A of this report.

- The modular design used to achieve disposal facilities of different capacities, using the earth-covered concrete vaults disposal technology, will conform to the codes and standards in Appendix A.

- Environmental surveillance and monitoring requirements will be based on the data in Table A-6 for the baseline monitoring during the pre-operations period; Table A-7 for the operations period and the closure period; and Table A-8 for the post-closure period (Appendix A).

- Class $\mathrm{A}$ waste and Class $\mathrm{B} / \mathrm{C}$ waste will be segregated and disposed of in separate concrete vaults constructed above grade. The Class $A$ vaults and the Class $B / C$ vaults will both be covered with earth cover at least $6.5 \mathrm{ft}$ thick.

- The earth cover system will be designed to Level Q quality assurance as defined in Section A.2.8.1 (Appendix A) of this report.

\subsection{Operating Assumptions}

Operating assumptions for the base case apply to the receipt of waste, placement of waste in the disposal facility, regulatory compliance, and waste packaging.

- Waste is assumed to be received at the site at a uniform rate of $30,000 \mathrm{ft}^{3}$ per year over the 30 -year operating life of the facility.

a. See Appendix B for a discussion of the dose assessment. 
- Waste is assumed to be packaged for transport in either a 55 -gal drum, a 4 by 4 by 8 -ft wooden or steel box, a 6.5 -ft-diameter by 6.5 -ft-tall unshielded cylinder, a 4 -ft-diameter by 4-ft-long shielded cylinder, and a more heavily shielded cylinder $1 \mathrm{ft}$ in diameter by $12 \mathrm{ft}$ long (CDR, Section 3.1.1, Design Basis Assumptions). ${ }^{1}$

- Waste will be received, stored, and placed in annual campaigns lasting two months.

- All waste sent to the disposal facility will meet the waste characteristic requirements of Section 61.56 of 10 CFR 61 . The burden of demonstrating compliance with these requirements is with the generator of the waste.

- Waste is assumed to be $97 \%$ Class $\mathrm{A}$ waste and $3 \%$ Class $\mathrm{B} / \mathrm{C}$ waste, by volume.

- The facility will not accept hazardous chemical or mixed waste.

- No volume reduction or other treatment capability is required on site.

- Operating requirements relating to environmental regulations are based on current standards and remain stable over time.

\subsection{Cost Estimating Assumptions}

- All costs will be presented in 1992 dollars. No escalation will be applied.

- A unit disposal charge will be calculated as the average amount that must be collected, on a level basis over the operating period, for each cubic foot of waste to recover preoperating, operating, closure, and post-closure costs. This analysis will consider the effects of Federal income taxes, interest, and profit, where applicable, using the assumptions presented in Section 3.3. This unit disposal charge will be calculated as a present value amount at the start of pre-operations (1992) using real interest rates that are net of inflation.

- Key financial parameters will be those stated in Table 3-19 (Section 3) of this report.

- Construction of the concrete vault will be accomplished by a subcontractor to the facility operator using a separate labor force from that used for site management and disposal operations.

- The technical and analytical parameters for the base case cost estimate and the sensitivity analyses are summarized in Table 2-1. The parameters were varied individually to create different sensitivity study cases; the specific cases and parameters are presented in Table 3-22 (Section 3).

- No allowance is made, nor is consideration given to any surcharges or other fees that may be placed on waste received for disposal, other than those required to meet the financial requirements of this study. 
- No allowance is made, nor is consideration given to taxes of a site specific nature, such as franchise, property taxes, sales or gross receipts taxes, or state or local income taxes, or to community assistance payments.

- Purchase cost for the site land was not considered because of the fact that such costs are site dependent and would not change the relative results between the base case and the various sensitivity cases.

Table 2-1. Technical and analytical parameters.

\begin{tabular}{lccc}
\hline \multicolumn{1}{c}{ Parameter } & Base value & \multicolumn{1}{c}{ Alternate parameters } \\
\hline Total capacity & $900,000 \mathrm{ft}^{3}$ & $300,000 \mathrm{ft}^{3}$ & $1,500,000 \mathrm{ft}^{3}$ \\
Annual rate & $30,000 \mathrm{ft}^{3} / \mathrm{yr}$ & $10,000 \mathrm{ft}^{3} / \mathrm{yr}$ & $50,000 \mathrm{ft}^{3} / \mathrm{yr}^{3}$ \\
Operating life & 30 years & 20 years & 40 years \\
Financing & $50 \%$ private & $100 \%$ private & $100 \%$ public \\
& $50 \%$ public & & $7 \%$ \\
Interest rate & $4 \%$ & $1 \%$ & \\
\hline
\end{tabular}




\section{ESTIMATED LIFE CYCLE COSTS}

\subsection{Cost Estimate}

The nature of this study requires a cost-estimating method that promotes accuracy, traceability, and consistency. Traceability is required to promote comparison of alternatives such as those represented by the base case and the alternatives considered for the sensitivity analysis. Consistency is required to ensure that the cost estimates for the alternative can be compared to the others. The cost-estimating method used for this study was selected after a careful evaluation of currently available techniques and methods, including a broad range of computer models. This review considered the requirements of this study together with the results of reviews conducted by others addressing topics such as model accuracy and validity.

\subsubsection{Method}

COSTPRO is a generic cost-estimating system that can be used to prepare cost estimates on projects from the planning stage through detailed design, and was selected to prepare cost estimates for construction elements of this study based on its accuracy, traceability, and consistency. One of the strengths of the system is its ability to manage up to four different work breakdown structures (WBSs) simultaneously without reentering the basic cost-estimate takeoff data. This is particularly helpful in instances where multiple format reporting may be required or where reporting requirements are not known in advance or can be expected to change over the life of the project. The model creates two basic files: a takeoff file, which contains all quantities and direct costs; and a factors file, which contains indirect cost factors, WBS codes, and estimate notes.

A product-oriented WBS was used to organize the estimate. This facilitates comparison of estimates and reduces estimate preparation and review time. The first level of the WBS is the project itself. The second level of the WBS separates the actions necessary to complete the project into four elements with numbering assigned as follows:

1.1 Pre-Operation. Direct and indirect costs incurred for selection, acquisition (other than land purchase cost, see Section 2.3), characterization, licensing, and construction of the disposal facility and support facilities are included under WBS 1.1, PreOperation. These costs include professional services required for siting, design, licensing, and construction management, subcontracted construction of site improvements, building and utilities, compliance with applicable regulatory requirements, and construction of land improvements, and support buildings.

1.2 Operating. Direct and indirect costs for receipt, inspection, placement of waste, and construction of waste cells are included in WBS 1.2. These costs include startup, maintenance, environmental monitoring, cell construction, and purchase of equipment during the operating life of the facility. 
1.3 Closure. Direct and indirect costs for WBS 1.3 include placement of the earthen cover, environmental monitoring, regulatory compliance, removal of all buildings except the equipment storage building and the guard station, and site operations during the five-year closure period.

1.4 Post-Closure. Direct and indirect costs for WBS 1.4 include minor custodial activity, environmental monitoring, and regulatory compliance during the post-closure (institutional control) period.

The third level of the WBS differentiates among elements of cost. Although the third-level categories vary within each Level II branch of the WBS, representative categories include personnel cost, construction equipment, equipment and vehicle maintenance, construction, and contingencies. The total estimated cost is summarized in Section 3.1.2.5 of this report.

A cost estimate was prepared for the base case using the WBS as an organizational tool. This cost estimate itself is a compilation of direct costs, such as labor, including the impact of personal protective equipment on productivity, labor fringe benefits, supervision, and material costs. The capital cost of construction and operating equipment, such as trucks or cranes, were estimated separately from the labor required to operate the equipment in accordance with the cost clements of WBS Level III.

Indirect costs include all activities that cannot be identified with a particular end product, such as legal services, insurance, general and administrative overhead, and fee. These costs are represented as a percentage of the direct cost and are displayed separately from direct cost and described in the estimate criteria.

Other cost elements that are estimated as a percentage of direct cost include escalation and contingency, each of which are tabulated separately. Escalation is an amount added to a cost to represent the cost of the underlying element if purchased at some date in the future. Escalation was not applied to any costs developed for this report and all costs are stated in 1992 dollars.

Contingency is an amount added to estimates to anticipate budget needs for the completion of work that is in the scope of the project, but that is not covered by the base amount before application of contingency. Cost estimates prepared for this study estimate contingency using the cost risk based analytical method developed for projects involving a range of risk and uncertainties. The methodology provides for the evaluation of proven risk factors, such as design completeness, in terms of importance and risk (likelihood of an unfavorable outcome). Contingency also provides for the inherent uncertainty associated with estimated unit prices, quantities, and methods of accomplishment (ranging from productivity to contracting). As such, contingency represents amounts that will be required to complete the project. All cost estimates prepared for this study include a contingency that has been estimated in a consistent, traceable manner following an established methodology. The results of the contingency analysis are provided in Appendix D. The factors considered when developing contingency include uncertainty in the estimated quantities, economic conditions, uncertainty in unit costs, the potential for design development, such as technological refinement, and minor modilications within the scope of the project. Contingency is not used to provide for scope additions, such as additional waste disposal capacity, beyond the original scope. 
Quality assurance and quality control are provided for all design data, cost estimates, analysis, and report narrative prepared for this study using procedures and policies meeting the requirements of NQA-1. Quality requirements have been applied to this project using a graded approach that considers the end use of the products being generated. Consistent with the requirement of the quality assurance program, all work is subjected to independent review to verify the correctness of the design, accuracy of cost estimates, adequacy of supporting documentation, and clarity of narrative in terms of the requirements of this study. Assumptions, where made, are noted and referenced.

3.1.1.1 Pre-Operating Costs. Pre-operating costs are those required to select, characterize, and license the site, design and construct the support structures, and support the start of operations. The cost of site selection, characterization, and licensure were estimated on the basis of professional judgement, the information provided in the conceptual design report, and a limited amount of historical data. The costs of these activities were estimated using a top down methodology and assigned to the appropriate WBS. Professional judgement was used in two ways. First, professional judgement was used to review the historical data and develop top down estimates for selected elements of cost. Second, professional judgement was used to develop a staffing plan for overall management, including administration and construction management. The resulting cost of these activities was determined using a resource loading algorithm.

The resource loading algorithm develops cost estimates by applying unit costs to the duration identified in the schedule. The costs are said to be schedule driven because the cost of a site safety inspector, for example, is determined by multiplying the fully burdened cost of an inspector by the duration of the requirement.

Construction costs for support facilities and other construction were estimated using a bottom up methodology based on the design drawings and the written description of facility requirements. Quantities of material, such as concrete, were estimated from the drawings and then the price was calculated by multiplying the quantity by the unit price. Overhead and profit for the construction contractor were added to the cost to determine the total construction cost.

The cost of engineeririg design was estimated as a percentage of construction with the percentages derived from in-house, actual cost data. The percentages used were:

- Support facilities: $15 \%$ of construction cost

- Construction equipment: $5 \%$ of purchase cost

- Land improvements and utilities: $12 \%$ of construction cost

- Cells: $10 \%$ of construction cost.

Construction services during the pre-operations phase will be provided by a subcontractor to the site operating contractor. This subcontractor will supply all of the construction equipment needed for the pre-operational phase. The costs associated with subcontractor furnished equipment, including depreciation, operation, and maintenance, are included in the construction cost. The option of acquiring the operations phase equipment during the pre-operations phase 
and using that equipment for construction activities was considered but rejected. The reasons for this included several factors, including the potential for improper maintenance or use of equipment by the construction subcontractor, the subcontractor's need for specialized equipment of a type, size, and quantity required to successfully complete the job, and minimization of liability-related complications.

3.1.1.2 Operating Costs. Operating costs include the construction of an average of one disposal module per year for each waste class (i.e., one cell for Class A waste and one cell for Class $\mathrm{B} / \mathrm{C}$ waste), waste receipt and emplacement operations, and construction of the cell lid. Each cell will be constructed at the beginning of the operating season, filled with waste, and then closed with a concrete cap when filled. Operating costs were estimated by resource loading the schedule. Cell construction costs were estimated using a bottom up technique. Operation support activities, such as sccurity and administration, were estimated using resource loading. Equipment acquisition costs, as well as equipment maintenance and operation costs, were estimated using unit costs based on vendor quotations. Environmental monitoring was estimated on the basis of unit costs obtained from vendors.

3.1.1.3 Closure Costs. Closure costs include the construction of the earth cover over the disposal cells, environmental surveillance and monitoring for the five-year closure period, and the preparation of closure documentation. Construction of the earth cover was estimated using the bottom up method. Surveillance and monitoring, support to closure operations, and the preparation of closure documentation were estimated using resource loading. Environmental monitoring was estimated on the basis of unit costs obtained from vendors.

3.1.1.4 Post-Closure Costs. Post-closure costs include minor custodial activity, site security, and environmental monitoring. Post-closure costs were estimated by resource loading the schedule to determine the cost of a year's worth of post-closure care and the cost extended for the requisite number of years. Environmental monitoring was estimated on the basis of unit costs obtained from vendors.

\subsubsection{Results}

The results of the cost-estimating process for each of the four periods in the life of the LLW facility are presented in Section 3.1.2.1 through 3.1.2.6.

3.1.2.1 Pre-Operating Costs. Pre-operating costs were estimated and scheduled to produce a time-phased cost plan. The cost estimate and time-phased cost plan for the base casc are summarized in Table 3-1.

The details of the pre-operating period costs are presented in Appendix E. Several of the principal cost components are presented in Tables 3-2, 3-3, and 3-4 as discussed below.

Unit costs for management support labor are summarized in Table 3-2. All labor rates are burdened by $100 \%$, which includes indirect costs such as labor fringe benefits, labor-related expenses (consumable supplies, travel, training), operating expenses (liability insurance, profit), and general administration costs. Technical support (site selection, site screening, environmental studies, procedure development, and site characterization), engineering design, licensing, and 


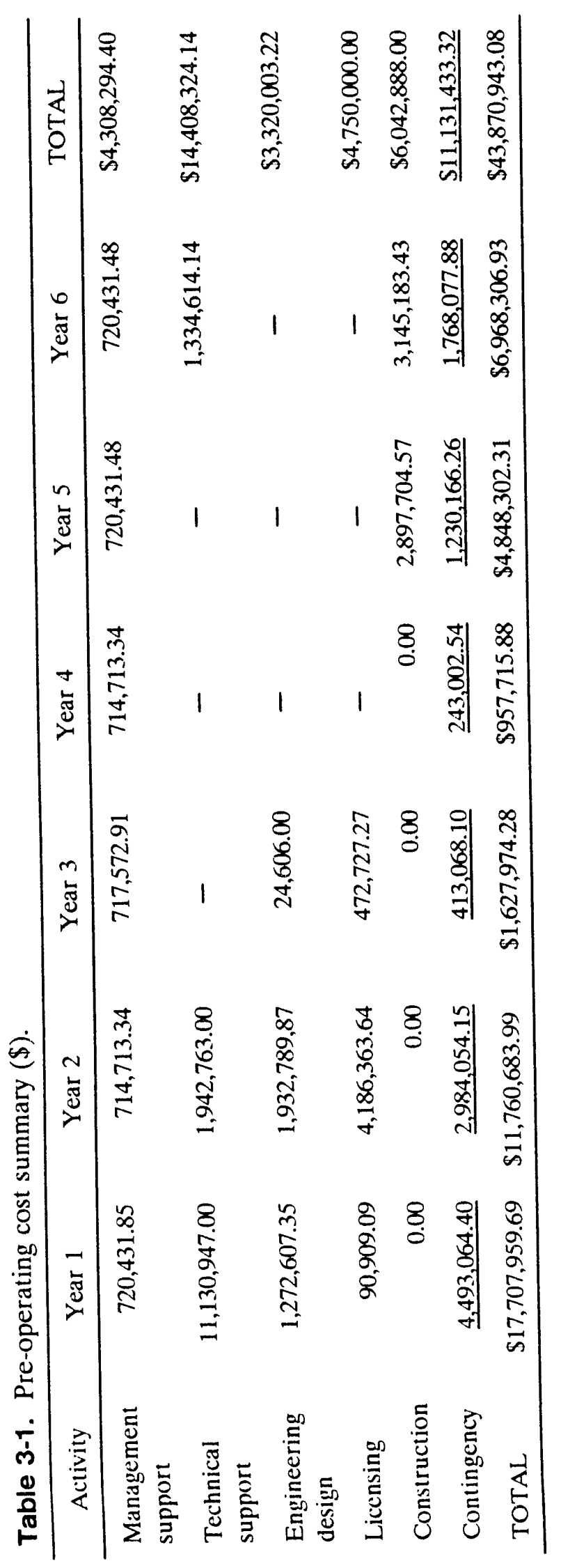


Table 3-2. Management support labor unit cost.

\begin{tabular}{lcc}
\hline \multicolumn{1}{c}{ Position } & Annual salary & $\begin{array}{c}\text { Monthly rate } \\
\text { with burden }\end{array}$ \\
\hline Site manager & $\$ 79,800$ & $\$ 13,300$ \\
Secretary & $\$ 18,000$ & $\$ 3,000$ \\
Accountant & $\$ 34,800$ & $\$ 5,800$ \\
Site operations supervisor & $\$ 49,800$ & $\$ 8,300$ \\
Site engineer and quality assurance & $\$ 45,000$ & $\$ 7,500$ \\
supervisor & $\$ 39,600$ & \\
Security chief & $\$ 24,600$ & $\$ 6,600$ \\
Security staff & $\$ 49,800$ & $\$ 4,100$ \\
Radiation safety officer & $\$ 37,800$ & $\$ 8,300$ \\
Senior health physics technician & $\$ 30,000$ & $\$ 6,300$ \\
Health physics technician & $\$ 15,000$ & $\$ 5,000$ \\
Clerk & $\$ 30,000$ & $\$ 2,500$ \\
Warehouseman & $\$ 33,000$ & $\$ 5,000$ \\
Mechanic & $\$ 36,600$ & $\$ 5,500$ \\
Disposal foreman & $\$ 31,800$ & $\$ 6,100$ \\
Equipment operator & $\$ 19,800$ & $\$ 5,300$ \\
Laborer & $\$ 19,800$ & $\$ 3,300$ \\
Disposal operator & $\$ 16,800$ & $\$ 3,300$ \\
Custodian & & $\$ 2,800$ \\
\hline & & \\
\hline
\end{tabular}

construction are all subcontracted activities. Total costs for management support labor are included in the management support activity in Table 3-1.

Costs for the one-time pre-operations sampling program, which will occur in Year 1 of the pre-operations period, are included in the technical support activity in Table 3-1, and are presented separately in Table 3-3.

Costs for the one-ycar baseline environmental monitoring program, which will occur immediately prior to the start of operations, are included in the technical support activity in Table 3-1, and are presented separately in Table 3-3. 


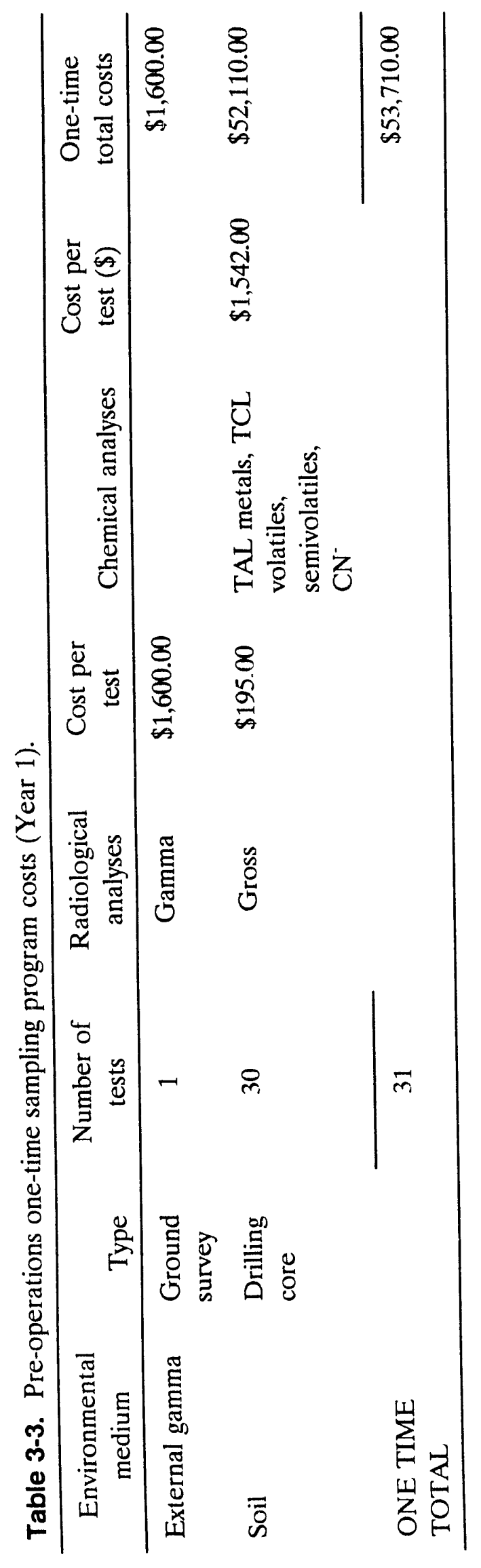




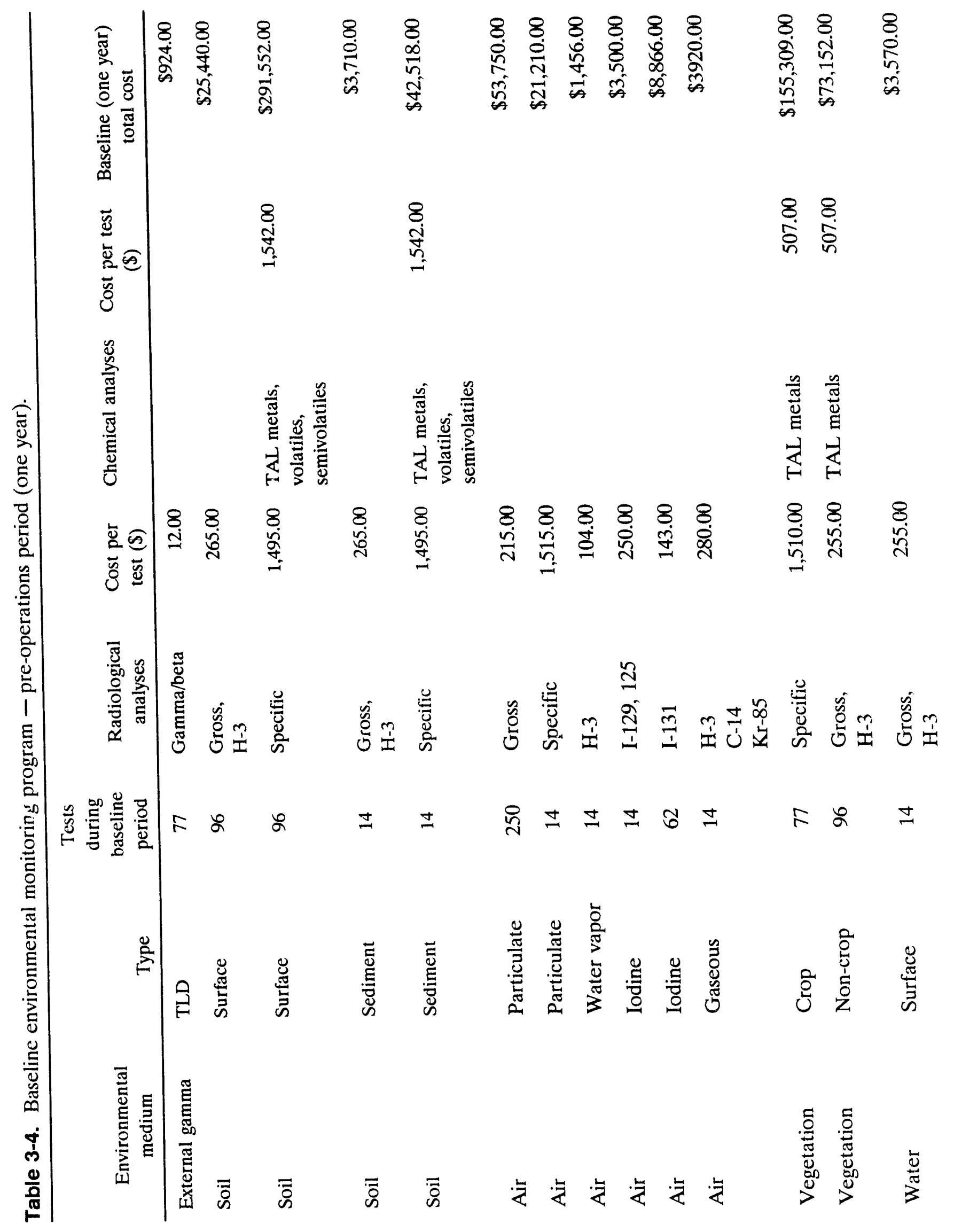




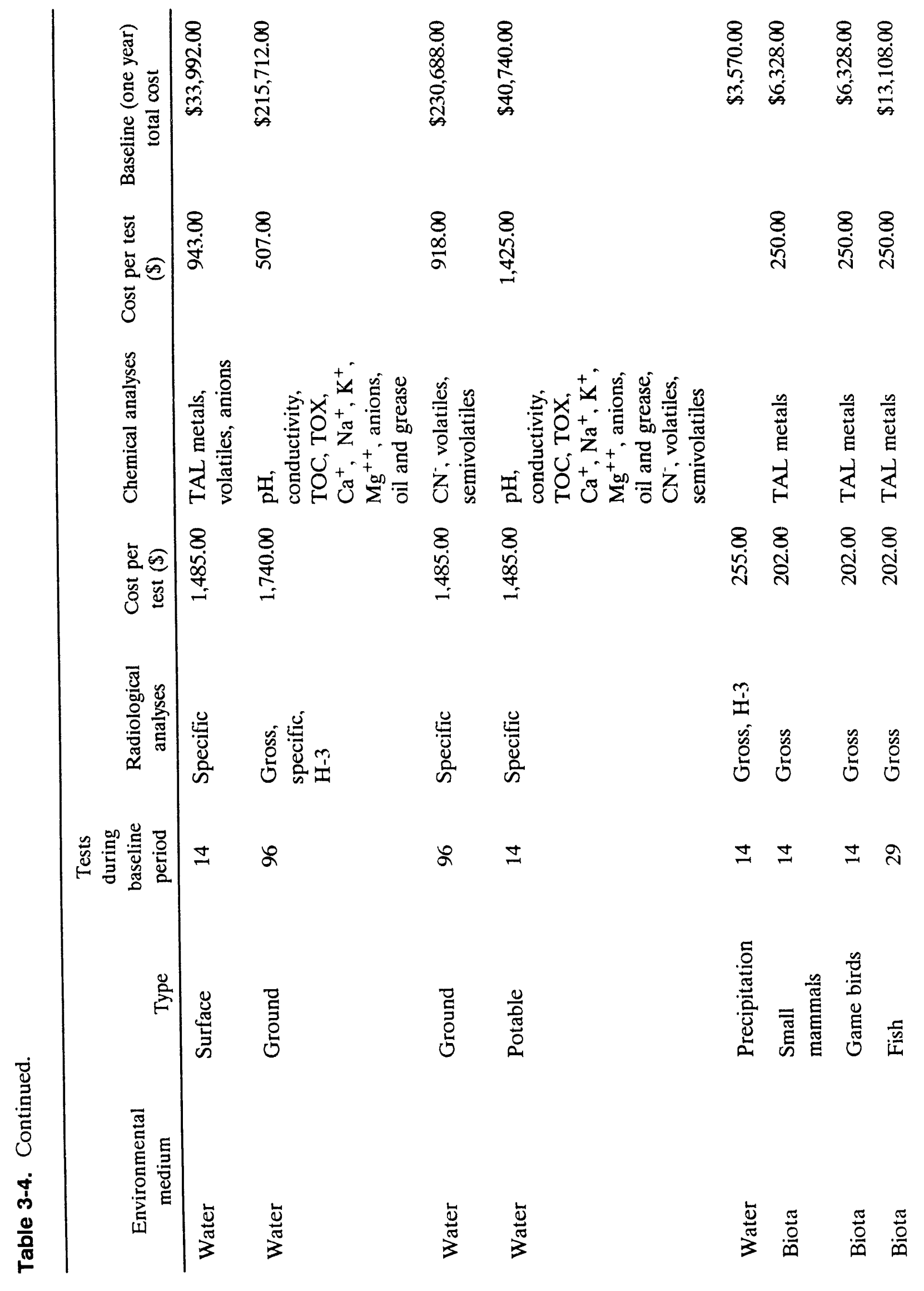




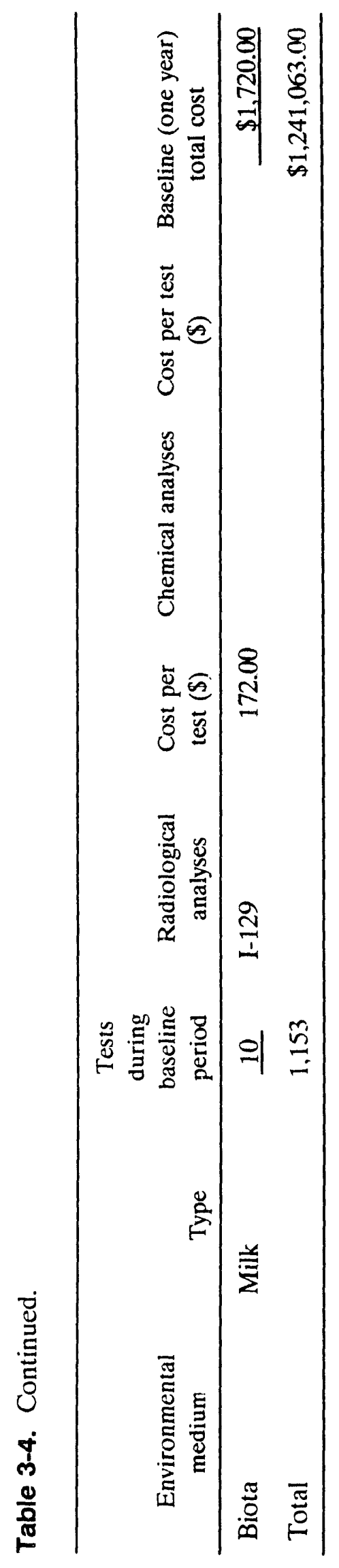


Staffing levels for each management support position identified for the pre-opcrational phase are summarized in Table 3-5.

3.1.2.2 Operating Costs. Operating costs were estimated and scheduled to produce a time-phased cost plan. The cost estimate and time-phased cost plan for the base case are summarized in Table 3-6.

Table 3-5. Pre-operating staff requirements.

\begin{tabular}{lc}
\hline \multicolumn{1}{c}{ Position } & $\begin{array}{c}\text { Number } \\
\text { required }\end{array}$ \\
\hline Accountant & 1 \\
Assistant engineer & 1 \\
Clerk & 2 \\
Radiation safety officer & ${ }^{\mathrm{a}}$ \\
Site manager & 1 \\
Secretary & 1 \\
Site engincer & 2 \\
\end{tabular}

a. Radiation safety officer needed only in the one-year baseline environmental monitoring period.

The details of the operating period costs are presented in Appendix E. Information regarding several of the principal cost components is presented in Tables 3-7, 3-8, 3-9, 3-10, and 3-11, as discussed helow.

The first year of operations inc:ludes sevcral activities that differ in scope and cost from those of subsequent years. These are: construction of the first two waste cells (one each for Class $\mathrm{A}$ and Class $\mathrm{B} / \mathrm{C}$ ) and equinment acquisition. The construction cost of the first cell of each type exceeds the cost of subsequent cells because the first cells are four-sided, whereas subsequent cells are three-sided using one side of a previously constructed cell. Equipment acquisition costs occur every 10 years, with the equipment purchased in the first year and again in year 11 and year 21 . Site management anu waste placement activities are unchanged fror 1 year to year over the 30 -year operating period.

Stafing levels for each site management position identified for the operational phase are summarized in Table 3-7. 


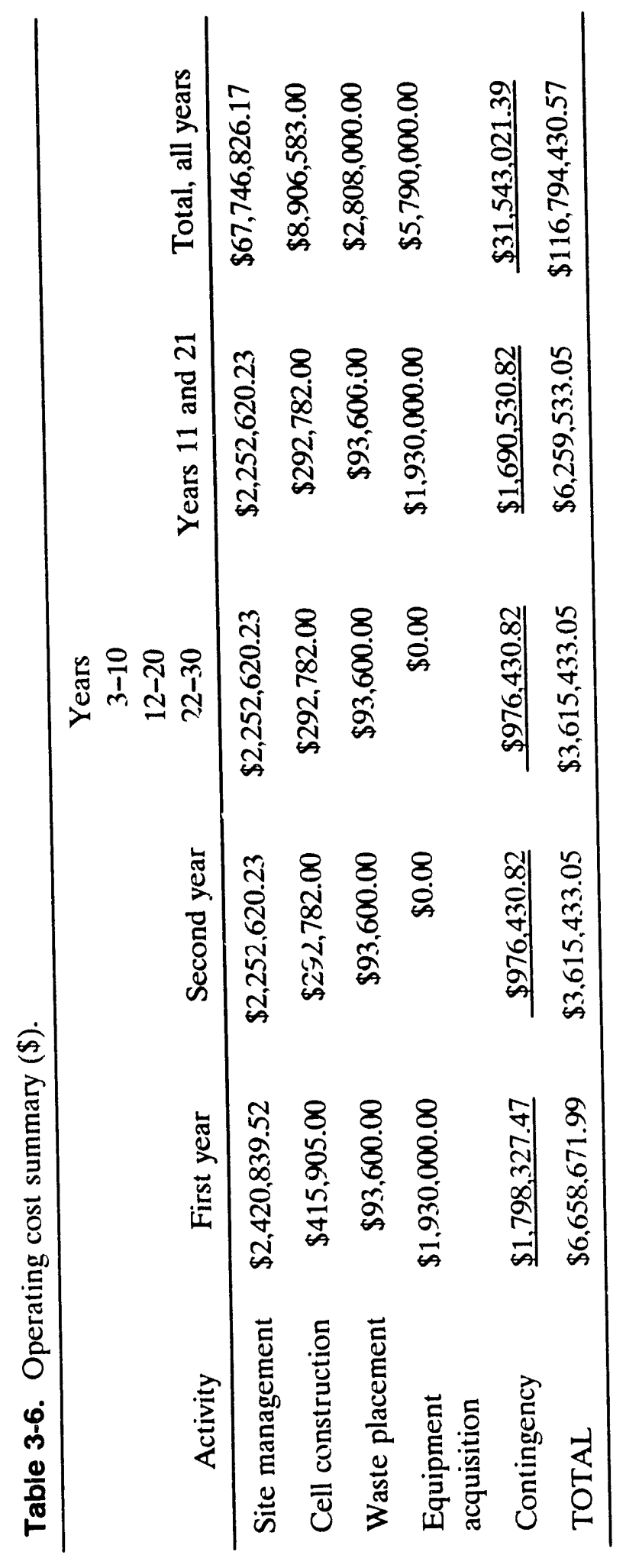


Table 3-7. Operating staff requirements site management.

\begin{tabular}{lc}
\multicolumn{1}{c}{ Position } & $\begin{array}{c}\text { Number } \\
\text { required }\end{array}$ \\
\hline Accountant & 1 \\
Clerk & 2 \\
Custodian & 2 \\
Senior health physics technician & 1 \\
Mechanic & 1 \\
Radiation safety officer & 1 \\
Sitc manager & 1 \\
Security chief & 1 \\
Security staff & 5 \\
Secretary & 2 \\
Site operations supervisor & 1 \\
Site engineer & 1 \\
Warehouseman & 1 \\
\hline
\end{tabular}

Table 3-8. Waste handling workload.

\begin{tabular}{|c|c|c|c|c|}
\hline \multirow[b]{2}{*}{$\begin{array}{l}\text { Shipping } \\
\text { container }\end{array}$} & \multicolumn{4}{|c|}{ Number of containers } \\
\hline & $\begin{array}{c}\text { Containers } \\
\text { per year, } \\
\text { Class A }\end{array}$ & $\begin{array}{l}\text { Containers } \\
\text { per year, } \\
\text { Class B/C }\end{array}$ & $\begin{array}{c}\text { Total } \\
\text { Containers } \\
\text { (per year), } \\
\text { all classes }\end{array}$ & $\begin{array}{c}\text { Total } \\
\text { containers } \\
\text { (per month), } \\
\text { all classes }\end{array}$ \\
\hline $\begin{array}{l}55 \text {-gal steel } \\
\text { drums in } \\
\text { pallets of } \\
\text { four each }\end{array}$ & 1,207 & 8 & 1,215 & 607 \\
\hline Buxes & 71 & 0 & 71 & 35 \\
\hline Liners & 5 & 0 & 5 & 3 \\
\hline Small casks & 193 & 15 & 208 & 104 \\
\hline $\begin{array}{l}\text { Horizontal } \\
\text { casks }\end{array}$ & 25 & 11 & 36 & 18 \\
\hline
\end{tabular}


Table 3-9. Waste handling staff requirements-temporary contract crew.

\begin{tabular}{lc}
\hline \multicolumn{1}{c}{ Operations } & Number required \\
\hline Disposal crew & 2 \\
Disposal foreman & 1 \\
Heavy equipment operator & 3 \\
Health physics technician & 2 \\
Security staff & 2 \\
\hline
\end{tabular}

Table 3-10. Equipment data.

\begin{tabular}{|c|c|c|c|c|c|}
\hline Type of equipment & $\begin{array}{l}\text { Number } \\
\text { required }\end{array}$ & $\begin{array}{l}\text { Capital cost of } \\
\text { equipment (10-year } \\
\text { purchase) }(\$)\end{array}$ & $\begin{array}{l}\text { Operate and } \\
\text { maintain per hour } \\
\text { cost }(\$)\end{array}$ & $\begin{array}{l}\text { Hours used } \\
\text { per year }\end{array}$ & $\begin{array}{l}\text { Annual operating and } \\
\text { maintenance cost (\$) }\end{array}$ \\
\hline Motor grader $/ 140 \mathrm{C}$ & 1 & $181,000.00$ & 15.00 & 1.000 & $15,000.00$ \\
\hline Wheel loader/936E & 1 & $125,000.00$ & 15.75 & 1,000 & $15,750.00$ \\
\hline 12 CY dump truck & 1 & $57,000.00$ & 12.00 & 1,000 & $12,000.00$ \\
\hline $\begin{array}{l}\text { Wheel tractor } \\
\text { backhoe/446 }\end{array}$ & 1 & $98,000.00$ & 13.00 & 1.000 & $13,000.00$ \\
\hline $\begin{array}{l}\text { Vibratory } \\
\text { compactor/CS433 }\end{array}$ & 1 & $75,000.00$ & 9.00 & 1,000 & $9,000.00$ \\
\hline $\begin{array}{l}\text { 4,000-gal water } \\
\text { truck }\end{array}$ & 1 & $70,000.00$ & 1.25 & 1,000 & $1,250.00$ \\
\hline 750 GPM tire truck & 1 & $125,000.00$ & 1.25 & 1,000 & $1,250.00$ \\
\hline Four-door sedan & 1 & $15,000.00$ & 1.25 & 1,000 & $1,250.00$ \\
\hline $\begin{array}{l}\text { Four-wheel drive } \\
\text { pickup }\end{array}$ & 2 (i) $\$ 15,000$ & $30,000,00$ & 1.25 & 1,000 & $2,500.00$ \\
\hline $\begin{array}{l}\text { 10-ton stake bed } \\
\text { truck }\end{array}$ & 1 & $35,000.00$ & 1.25 & 1,000 & $1,250.00$ \\
\hline 12 passenger van & 1 & 22.000 .00 & 1.25 & 1,000 & $1,250.00$ \\
\hline $4-$ ion forklift & 1 & 32.000 .00 & 6.00 & 1.000 & $6,000.00$ \\
\hline 15-ton forklift & 1 & 80.000 .00 & 8.00 & 1,000 & $8,000,00$ \\
\hline $\begin{array}{l}60-\text { ton lattice work } \\
\text { crane }\end{array}$ & 2 (a) $\$ 450,000$ & $900,000.00$ & 19.00 & 1,000 & $38,000,00$ \\
\hline Concrete truck & 1 & $85,000.00$ & 14.00 & 1,000 & $\begin{array}{r}14,000.00 \\
\end{array}$ \\
\hline TOTALS & 17 & $\$ 1,930,000.00$ & & & $\$ 139,500.00$ \\
\hline
\end{tabular}




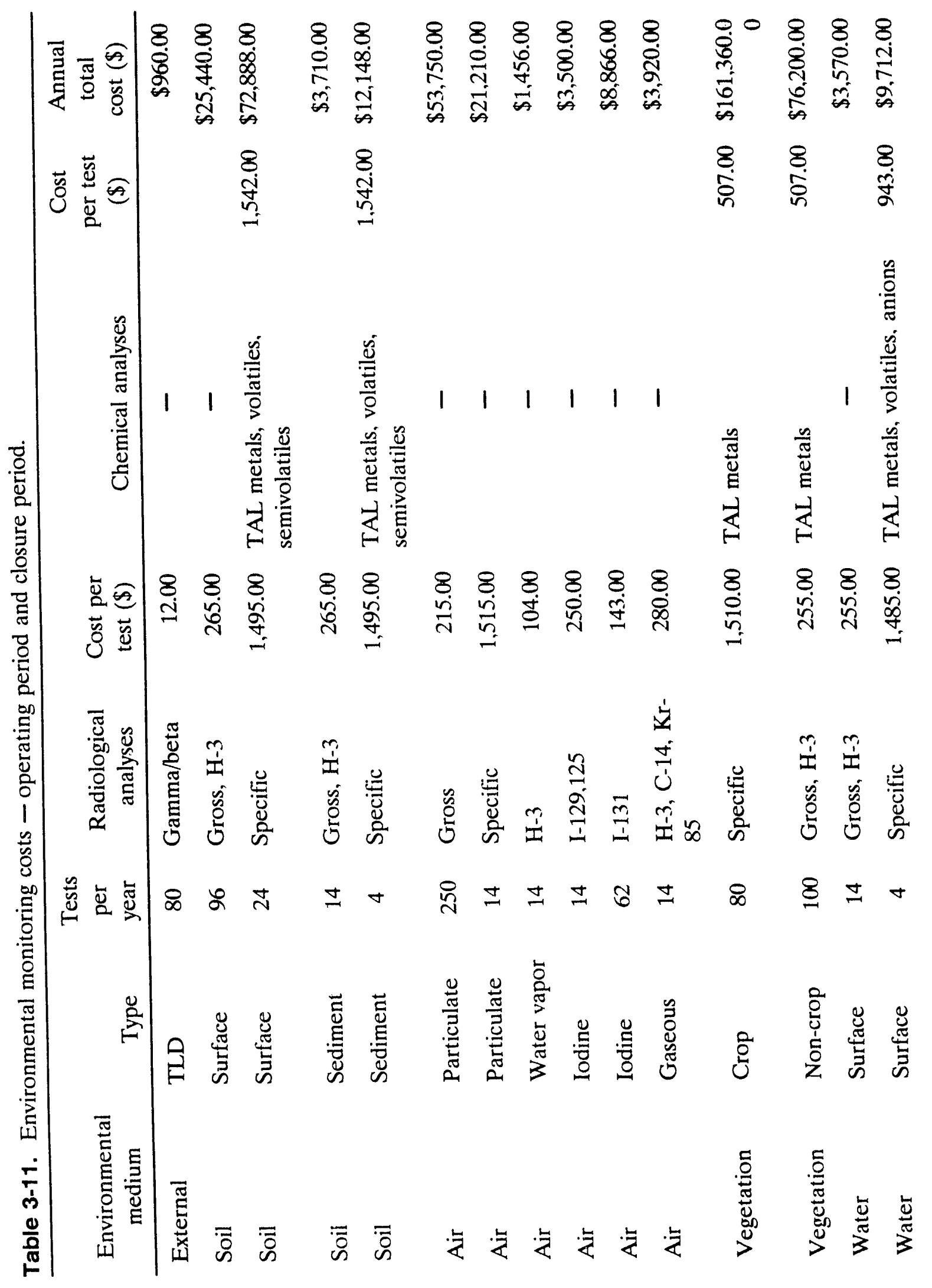




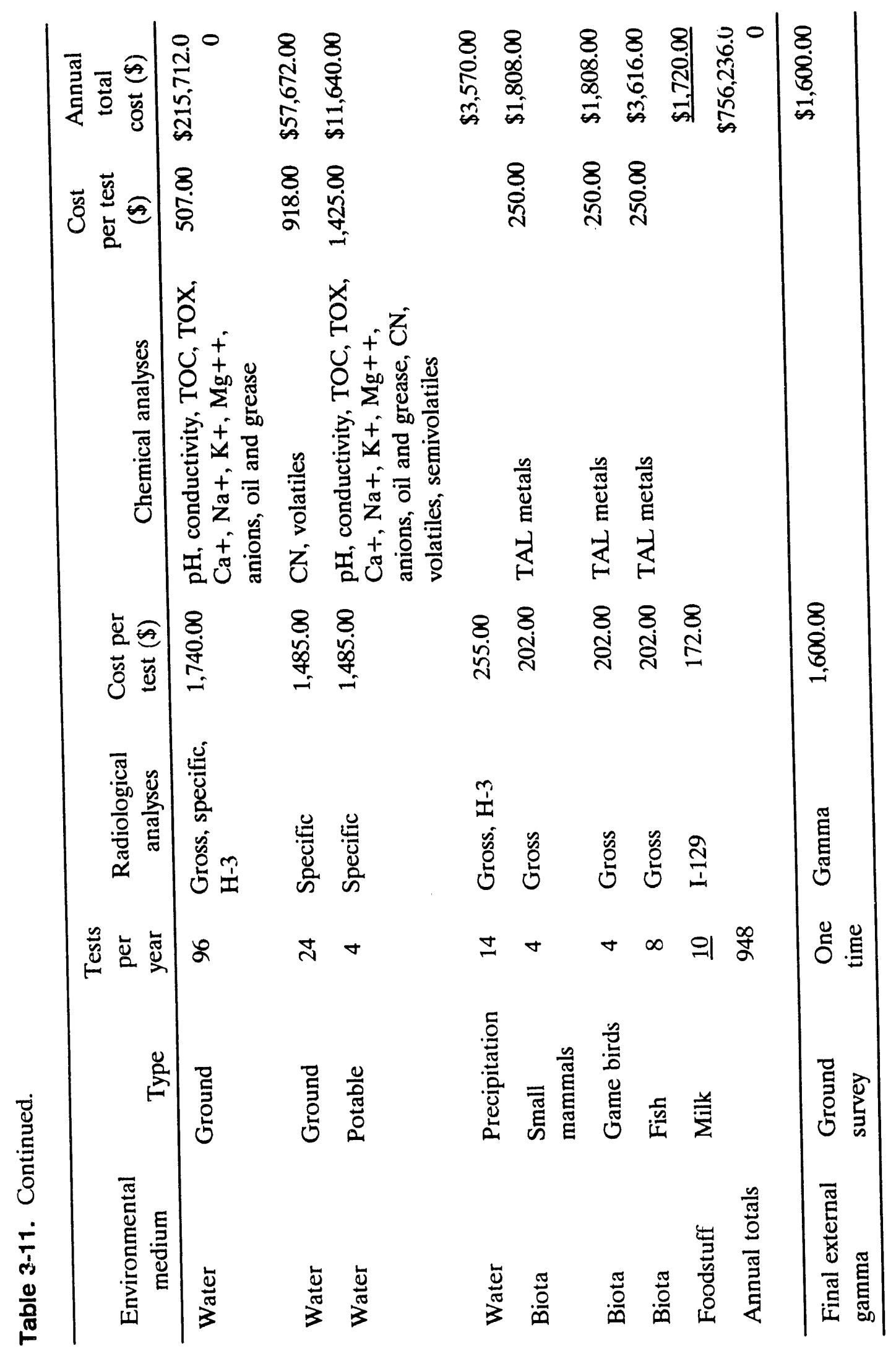


Waste disposal and handling operations will be handled by a specialized crew hired for that purpose on a temporary, contract basis. This approach was adopted because the annual waste volume is not great enough to justify a full-time staff. The base case assumes a two- month period for waste disposal operations and, together with the forecast waste volume and container mix, translated to a monthly workload of waste packages as shown in Table 3-8.

Waste handling crew staffing requirements are presented in Table 3-9, and the assignments of each position are summarized as follows:

- Disposal foreman. Supervises all operations of the waste handling crew.

- Disposal crew. Conducts waste handling opcrations, including placement of drums within the disposal cell (positioning, guying during lifting), operation of the batch plant for cell fill material (loading of material from batch plant hopper to dump truck, transfer from dump truck to bucket, guying of bucket during lifting and placement of fill), driving the truck from the waste storage or waste receiving building to the disposal area, maintaining operational documentation during the waste emplacement operation, site maintenance during operations (cleanup, protection against inclement weather), and preparation of the facility for temporary closure in between waste emplacement campaigns (cleanup, temporary storage of equipment and material, and completion of documentation). Special measures may be required during placement of Class $\mathrm{B} / \mathrm{C}$ waste.

- Heavy equipment operator. Operates the forklifts required to unload the waste when received at the facility and moves the waste from the truck to the storage area or to a waiting truck for transport to the disposal cell. When waste is placed in temporary storage, moves the waste to and from storage. Operates the crane required to lift the waste containers into the cell, and operates the crane for other activities, such as placement of fill within the cell.

- Health physics technician. Provides operational health physics support during waste handling operations, reviews documentatior, for waste containers, and assists in the preparation of operational activity reports. Collects samples as required to support operational requirements during the waste operations period.

- Security staff. Two additional security staff are provided during waste handling operations to maintain continuous surveillance of the disposal site, access control, and control of equipment and property.

Capital costs for equipment purchasc, as well as costs for equipment maintenance and operation, facility maintenance, and analytical services were estimated on the basis of unit prices obtained from suppliers or vendors. Equipment quantitics, purchase costs, usage data, and operating costs are summarized in Table 3-10. The capital cost of equipment is the amount to be spent on new equipment every 10 years, and the annual operating cost is the amount to be spent for maintaining and operating the equipment every year. The capital cost of equipment from Table 3-10 is incorporated in the equipment acquisition activity of Table 3-6. The annual operating cost of equipment from Table $3-10$ is incorporated in the site management activity of 
Table 3-6. Facility maintenance and operations costs are estimated at $2 \%$ of facility acquisition and are equal to $\$ 161,926$ per year, and are incorporated into the site management activity of Table 3-6. Annual operating period costs for environmental monitoring during the operating period are summarized in Table 3-11. These costs are incorporated in the site management activity of Table 3-6 and include the type of test, number required per year, the unit cost of each, and the total annual costs.

3.1.2.3 Closure Costs. Closure costs were estimated and scheduled to produce a timephased cost plan. The cost estimate and time-phased cost plan for the base case are summarized in Table 3-12.

The earth cover will be constructed in the first year of the closure period and then monitored for five years to ensure acceptable performance. Site management costs include the staff identified in Table 3-13, and annual environmental monitoring costs. The annual environmental monitoring program and costs during the closure period are included in the site management activity and are identical to tho:e of the operations period, except for the inclusion of a final one-time external gamma ground survey, and are presented in Table 3-11.

Table 3-12. Closure cost summary (\$).

\begin{tabular}{|c|c|c|c|c|c|}
\hline Activity & Year 37 & Year 38 & Year 39 and 40 & Year 41 & Total, all years \\
\hline $\begin{array}{l}\text { Site } \\
\text { management }\end{array}$ & $2,116,810.00$ & $1,806,888.00$ & $1,806,888.00$ & $1,785,291.55$ & $\$ 9,322,765.55$ \\
\hline $\begin{array}{l}\text { Earth cover } \\
\text { construction }\end{array}$ & $1,948,746.00$ & - & - & - & $\$ 1,948,746.00$ \\
\hline $\begin{array}{l}\text { Building } \\
\text { demolition }\end{array}$ & - & $1,050,149.00$ & - & - & $\$ 1,050,149.00$ \\
\hline $\begin{array}{l}\text { Equipment } \\
\text { acquisition }\end{array}$ & $128,000.00$ & - & - & - & $\$ 128,000.00$ \\
\hline Contingency & $1,341,937.92$ & $914,251.84$ & $578,204.16$ & $571,293.30$ & $\$ 3,983,891.38$ \\
\hline TOTAL & $\$ 5,535,493.92$ & $\$ 3,771,288.94$ & $\$ 2,385,092.16$ & $\$ 2,356,584.85$ & $\$ 16,433,551.93$ \\
\hline
\end{tabular}

Table 3-13. Site management staff requirements.

\begin{tabular}{lc}
\multicolumn{1}{c}{ Position } & Number required \\
\hline Accountant & 1 \\
Clerk & 1 \\
Custodian & 1 \\
Radiation safety & 1 \\
Site manager & 1 \\
Security chief & 1 \\
Security staff & 4 \\
\hline
\end{tabular}


3.1.2.4 Post-Closure Costs. Post-closure costs were estimated and scheduled to produce a time-phased cost plan for the 100 -year post-closure period. The cost estimate and time-phased cost plan for the base case are summarized in Table 3-14. Site management costs include the staff identified in Table 3-15.

The environmental monitoring program and costs for the post-closure period are presented in Table 3-16 and are incorporated in the environmental monitoring activity of Table 3-14.

3.1.2.5 Cost Summary. Total estimated costs for the base case are summarized in Table 3-17. These amounts are presented in 1992 dollars. The total estimated cost for the base case is also presented using a code of accounts format developed by the National Low-Level

Table 3-14. Post-closure cost summary.

\begin{tabular}{lcc}
\multicolumn{1}{c}{ Activity } & $\begin{array}{c}\text { Annual cost } \\
(\$)\end{array}$ & \multicolumn{1}{c}{ Total } \\
\hline Site management & $201,200.00$ & $\$ 20,120,000.00$ \\
Environmental monitoring & $75,960.00$ & $\$ 7,596,000.00$ \\
Contingency & $\underline{124,722.00}$ & $\$ 12,472,200.00$ \\
Total & $\$ 401,882.00$ & $\$ 40,188,200.00$ \\
\hline
\end{tabular}

Table 3-15. Site management stafl requirements.

\begin{tabular}{lc}
\hline \multicolumn{1}{c}{ Position } & Number required \\
\hline Radiation safety oflicer & 1 \\
Security chicf & 1 \\
\hline
\end{tabular}

Table 3-16. Environmental monitoring costs-post-closure period.

\begin{tabular}{|c|c|c|c|c|c|c|c|}
\hline $\begin{array}{l}\text { Envirommental } \\
\text { medium }\end{array}$ & Type & $\begin{array}{l}\text { Tests } \\
\text { per } \\
\text { year }\end{array}$ & $\begin{array}{l}\text { Radiological } \\
\text { analyses }\end{array}$ & $\begin{array}{l}\text { Cost per } \\
\text { test }(\$)\end{array}$ & Chemical analyses & $\begin{array}{c}\text { Cost per } \\
\text { test }(\$)\end{array}$ & $\begin{array}{l}\text { Annual total } \\
\text { cost }(\$)\end{array}$ \\
\hline Water & Ground & 24 & $\begin{array}{l}\text { Gross, } \\
\text { specilic, 11-3 }\end{array}$ & $1,740.00$ & $\begin{array}{l}\text { pH, conductivity, } \\
\mathrm{TOC}^{\mathrm{TOX}} \\
\mathrm{Ca}^{+}, \mathrm{Na}^{+}, \mathrm{K}^{+}, \\
\mathrm{Mg}^{++} \text {, anions,oil } \\
\text { and grease }\end{array}$ & 507.00 & $\$ 53,928.00$ \\
\hline Water & Ground & 24 & - & & $\begin{array}{l}\mathrm{CN}^{-} \text {, volatiles, } \\
\text { senivolatiles }\end{array}$ & 918.00 & $\$ 22,032.00$ \\
\hline TO'TAIS & & 48 & & & & & $\$ 75,960.00$ \\
\hline
\end{tabular}


Radioactive Waste Management Program and is provided in Appendix E. Note that the unit disposal charge values presented elsewhere in this report are not presented in 1992 dollars. Instead, they use present value calculations to reflect the effects of expenditures over time and thus, there will be differences between the total estimated cost and the present value of total expenditures.

Table 3-17. Cost summary.

\begin{tabular}{lcc}
\multicolumn{1}{c}{ Phase } & Duration & Total cost $(\$)$ \\
\hline Pre-operating & 6 years & $43,870,943.08$ \\
Operating & 30 years & $116,794,430.57$ \\
Closure & 5 years & $16,433,551.93$ \\
Post-closure & 100 years & $40,188,200.00$ \\
TOTAL & 141 years & $217,287,125.57$ \\
\hline
\end{tabular}

3.1.2.6 Cost Summary Code of Accounts. Total estimated costs for the base case are summarized in Appendix E using a code of accounts format developed by the National Low-Level Radioactive Waste Management Program. Detailed supporting calculations are also provided in Appendix E.

\subsection{Schedule}

The schedule shows the time period over which work is to be accomplished and integrates all of the activities and tasks required to construct, operate, close, and care for the disposal facility. The schedule depicts the sequencing and time-phasing of all work, and is organized to follow the WBS.

\subsubsection{Method}

The sequencing of the tasks within the schedule involves both the duration of the task and dependencies between tasks. Predecessor tasks are those that must be completed before the task being scheduled can start. Similarly, other successor tasks may depend on the completion of the task being scheduled. A task without a predecessor is a starting point and a task without a successor is a finishing point. TIMELINE software was selected for developing and displaying the schedule.

Professional judgement and historical data were used to develop schedule logic and task duration estimates. Factors considered in establishing durations included the amount of work to be performed, the resources available to perform the work, time requirements for public or regulatory reviews, and operating parameters. Factors considered in establishing schedule logic included operating interfaces, such as the need to construct certain elements of the facility before others, and regulatory constraints, such as the need to obtain permits or other approvals prior to beginning some tasks. 
The Gantt chart format was selected to display the schedule. Once the schedule is completed and costs are assigned to the activities in the WBS, a time-phased expenditure plan is calculated. This calculation is accomplished by spreading the cost of an individual WBS element evenly over the duration of that element and adding the cost of all elements to determine the total annual funding required for each year of operation.

\subsubsection{Results}

The schedule follows the WBS and is organized into four main phases:

- Pre-operations

- Operations

- Closure

- Post-closure.

Figure 3-1 shows the overall project schedule. Clarity of presentation was maintained by compressing years 3 through 30 of the operational period into a single space on the schedule. The post-closure period is also represented by a single space in Figure 3-1. The pre-operations phase of the schedule is shown in enlarged scale in Figure 3-2, and begins with the start of the project and concludes six years later with the start of operations. Major milestones within the pre-operations phase of the schedule include submission of a license application, license approval, and the start of construction.

The operations phase of the schedule is shown in Figure 3-3 and begins when the facility is operationally ready, including completion of all necessary construction, startup of all facilities, staffing of all new operational staff positions, receipt of all licenses and permits, and certification of waste generator's waste characterization program for shipment of waste. The first year of facility operations begins with construction of the first waste cells (one each for Class A waste and Class $\mathrm{B} / \mathrm{C}$ waste), and acquisition of equipment. It is recognized that acquisition planning for equipment will begin in the pre-operations phase, but the receipt of equipment is shown in the operations phase for consisiency since the equipment will be replaced every 10 years during the operations phase. During the first year of operations, the waste disposal cell is constructed, and waste emplacement begins and continues for two months. Supplementary personnel will be hired for this period to augment permanent site management resources. At the end of the waste placement period, the cell will be backfilled with sand or sandy gravel as appropriate, and a concrete lid will be placed over the filled cell. The facility will cease waste operations for approximately eight months until the start of the next annual campaign.

The schedule for succecding years, except for years when equipment is replaced, is the same as that of the first year.

The elosure and post-closure schedules are shown in Figure 3-4. Closure follows the operating period and continues for five years. During this period, all waste operations cease and the linal, permanent earth cover is installed over the concrete vaults. The closure period provides 


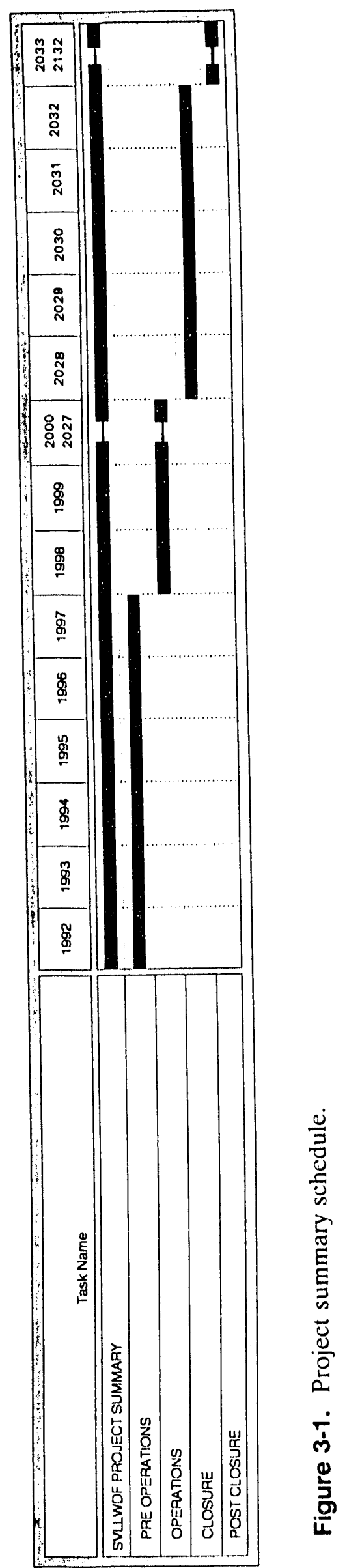




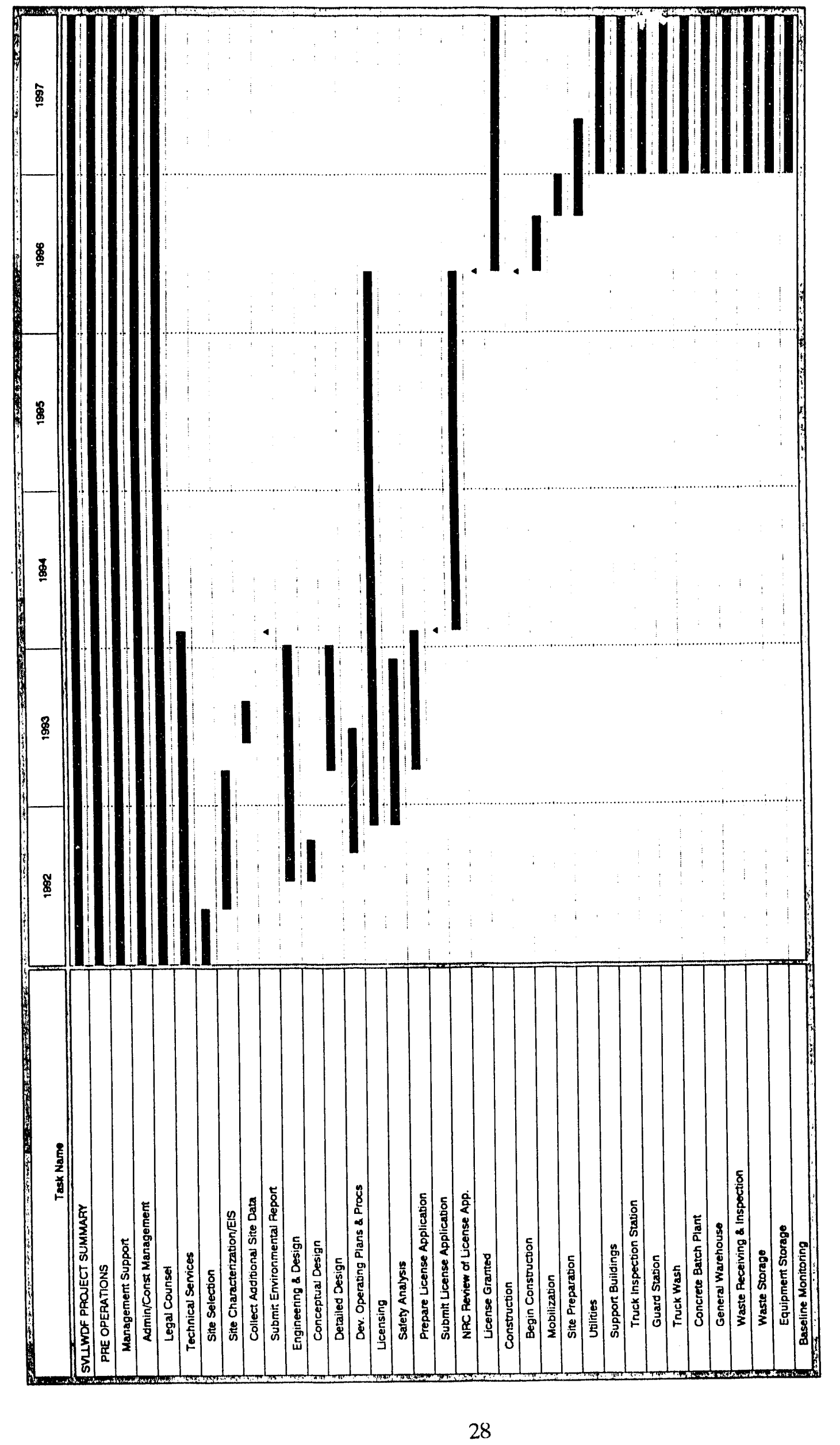

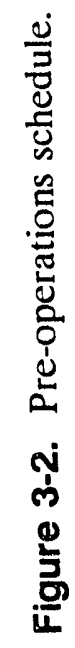




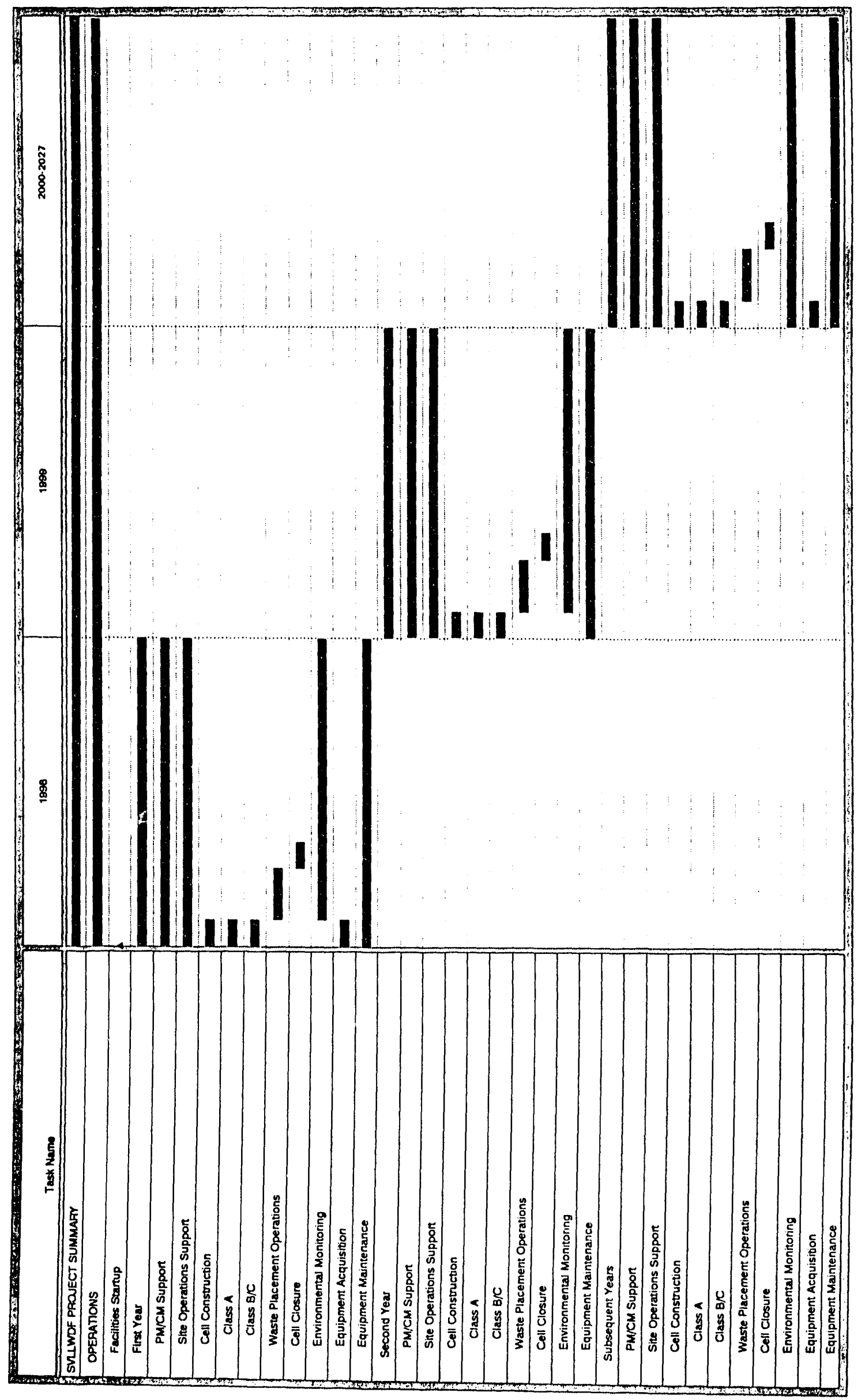

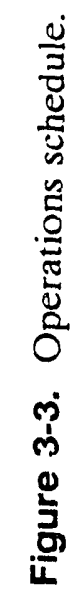




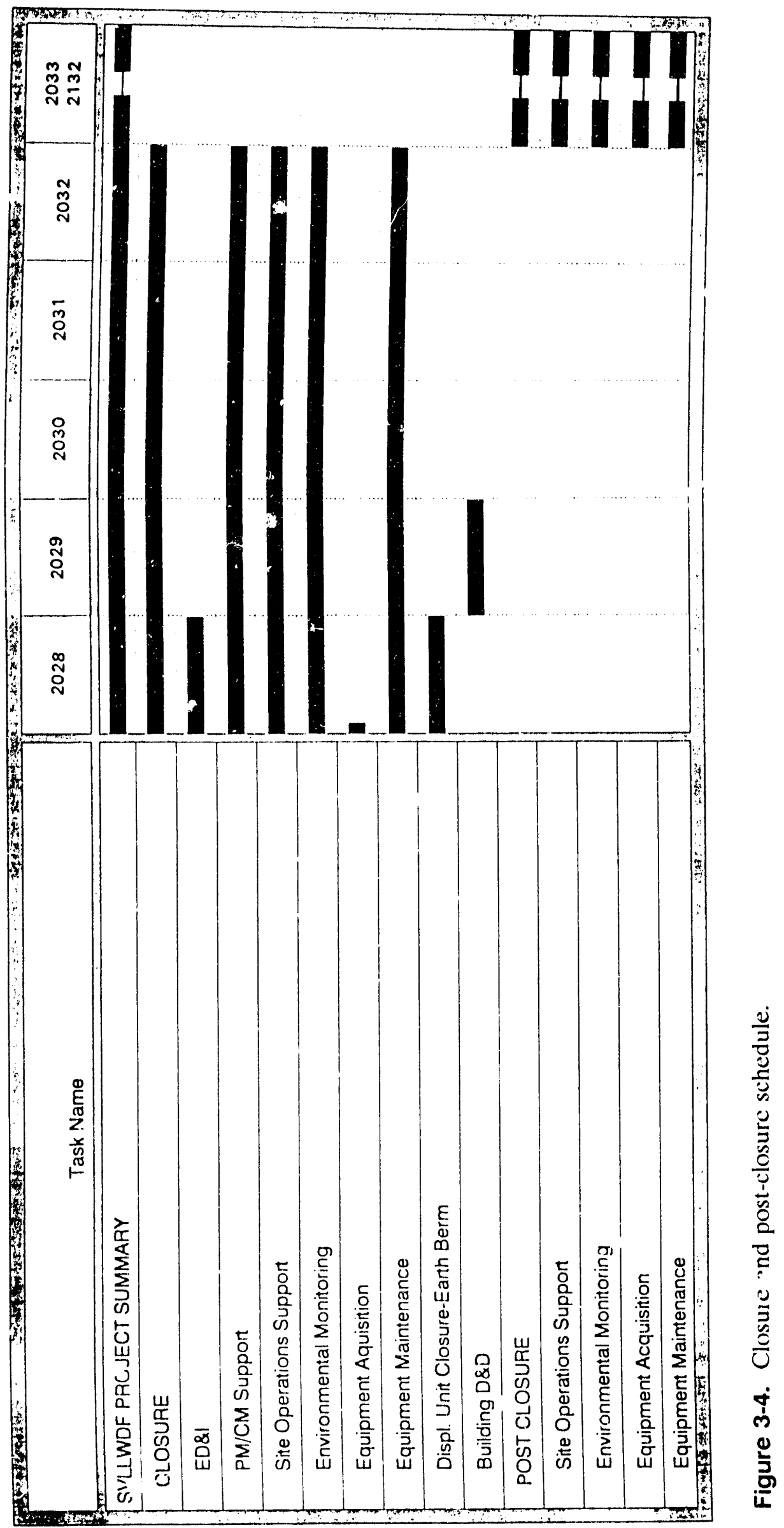


time for a transition from the site operator to the state, which will assume responsibility for the site during post-closure. The post-closure period begins immediately after the closure period and continues, in all cases, for 100 years.

\subsection{Unit Disposal Charge}

A unit disposal charge was calculated for the base case and the alternate cases selected for serisitivity analysis. The objective of using a unit disposal charge is to allow comparison of all crses on the basis of the charge to be made for each cubic foot of waste disposed by waste renerators. The rationale and prucedures to develop the unit disposal charge are presented in this section.

It is important to note that the life-cycle costs developed in Section 3.1, Cost Estimate, were calculated in base year 1992 dollars, without applying escalation. It is also important to note that the present value analysis method is used to calculate and compare costs for the remainder of this report in Section 3.3, Unit Disposal Charge, Section 3.4, Sensitivity Analysis, and Section 5, Summary.

\subsubsection{Method}

The alternative cases analyzed using sensitivity analysis have variations in key parameters, which cause significant differences in disposal costs as measured on a per cubic foot of waste basis. In adjition, the expenditures over the project life vary differently as a function of time for the base case and for the various alternative cases.

The present value method is a widely used and recommended economic analysis method for comparing capital investment projects. This method allows comparisons of projects having different capital costs, financing costs, operating costs, maintenance costs, productivity, and useful lives. In general, alternatives may be compared on a total cost basis, when the performance (i.e., total disposed volume) of the alternatives is the same. However, alternatives must be compared on the basis of the cost per unit of performance (i.e., per cubic foot of waste disposed) when the perlormance of the alternatives varies (i.e., different total disposal volume). Therefore, since the alternative cases involved different performance rates, and different costs over time, the present value method was utilized in this report to calculate waste disposal charges on a cost per cubic foot of waste disposed basis, as further presented below.

3.3.1.1 Present Value Cost Comparison Methodology. When evaluating and comparing the costs of alternative projects, a principal question usually asked is "What is the cost of each alternative?" Cost may mean total cost or a cost per unit of production, for example. A common decision problem occurs when two alternatives are considered, as shown in Table 3-18.

Typically, capital costs are incurred over a short construction period, whereas operating costs are incurred over a long operating life. Both the capital cost and operating cost affect the total cost of a project, and the related cost per unit of production or performance. 
For example, it is possible that the sum of capital costs and lifetime operating costs, as measured in base year dollars, could be similar for the two alternates in Table 3-18. However, when the present value is calculated, the costs of the alternates are likely to be quite different and show a distinct economic advantage for one alternate, depending on when expenditures occur. When using present value, expenditures in the future are discounted more than costs that occur in the relatively near term. In addition, the effects of different unit production rates must be accounted for by calculating a present value unit production cost for each alternate in order to properly compare the economics of each alternate.

Table 3-18. Examples of alternate investments.

\begin{tabular}{|c|c|c|c|}
\hline Alternate & $\begin{array}{c}\text { Initial } \\
\text { capital cost }\end{array}$ & Operating costs & $\begin{array}{l}\text { Unit } \\
\text { production } \\
\text { rate }\end{array}$ \\
\hline Alternate A & Higher & Lower & Higher \\
\hline Alternate B & Lower & Higher & Lower \\
\hline
\end{tabular}

Therefore, when the timing of an expenditure influences its true cost, it is important to compare alternatives as of a common point in time. This ensures fair comparisons and good decisions by adjusting the time-dependent value of each expenditure to a common reference date. The present value technique allows for such comparisons.

3.3.1.2 Present Value Analysis. As an introduction to the analysis methodology used in this report, this section presents the basic elements of present value analysis.

A main concept of present value analysis is that monetary transactions in the future have a lower cost or value than the same transaction would have if made today, because of the time value of money. The present value of a monetary transaction occurring in the future is calculated using a form of the compound interest formula, which is shown below:

$$
\mathrm{S} \quad=\mathrm{p}(1+i)^{\mathrm{N}}
$$

where

$\mathrm{p}=$ principal amount invested

$i=$ interest rate to be earned in each time period

$\mathrm{N}=$ number of time periods over which interest is compounded

$\mathrm{S}=$ total amount of principal and interest earned after $\mathrm{N}$ time periods, i.e., the new principal amount after $\mathrm{N}$ time periods. 
This formula can be rearranged as follows to derive the present value formula:

$$
\mathrm{p} \quad \frac{\mathrm{S}}{(1+i)^{\mathrm{N}}}
$$

When the amount of a future monetary transaction at a future date is known, the present value formula will determine the value of the future monetary transaction in terms of present value. In present value analyses, the variables in the formula are generally referred to as follows:

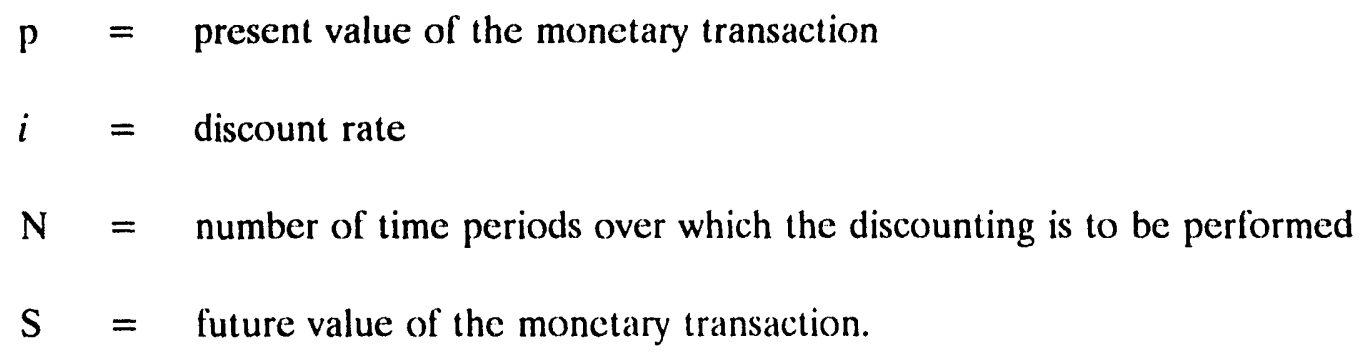

Genera:y, the discount rate chosen for present value analysis is closely related to or equal to an alternate rate of investment return available to the entity making an investment. Inflation rates can be, and generally are, different than the discount rate used in present value calculations. Such alternate rates of investment returns can usually be related to the rate of inflation projected and are generally greater than the rate of inflation when averaged over long time periods.

3.3.1.3 Unit Disposal Charge. Level unit charges for disposal of a cubic foot of waste were calculated on a present value basis for the base case and each alternative considered in the sensitivity analysis. The present value level unit disposal charge is the amount that must be charged during the operating period, per cubic foot of waste, to recover all life-cycle costs incurred for pre-operational, equipment, operational, closure, and post-closure expenses, including taxes, debt service, and profit where applicable. The unit disposal charge was calculated by dividing the level annual net present value of the revenue requirements (derived from life cycle costs) by the annual volume of waste disposed.

The life-cycle cost of the facility includes consideration of a number of factors. In addition to direct costs, there are indirect costs, which include taxes, profit or lee to the operator, interest on borrowed funds, and economic escalation. There are no taxes or profit considerations (other than those of subcontractors) in the case of public linancing. When private financing is considered, the pre-tax return on equity investment is reduced by the applicable income taxes in order to compute the after-tax return on equity investment. In all cases where private ownership and financing are involved, the private enterprise was assumed to operate on a stand-alone basis for tax purposes. Thus, no corporate tax consolidation issues were addressed. For the purpose of this study, the operating entity is assumed to capitalize all pre-operational costs for amortization and/or depreciation over the facility operating life.

The following terms, and their associated values, are stated in Table 3-19 and explained here: 
- Cost of debt. The percentage interest rate charged to the borrower by the lender. Costs for debt used in this report were assumed to be real interest rates, net of inflation.

- Return on equity. The annual after-tax rate of return required by a privately owned enterprise on the amount of outstanding equity investment. The equity return percentage rate used in this study was assumed to be a real return rate, net of inflation.

- Inflation rate. The percentage rate of increase in unit costs accruing over time because of changes in the value of the monetary unit. The inflation rate was assumed to be zero for this study.

- Marginal income tax rate. The highest percentage Federal tax rate applied to corporate earnings (without consideration of surcharges). The 1992 Federal tax rate for corporate income was used in this study.

Table 3-19. Key financial parametcrs - base casc.

\begin{tabular}{lcc}
\multicolumn{1}{c}{ Parameter } & Public & Private \\
\hline Cost of debt $(\% / y r)$ & 4.0 & 5.0 \\
Return on equity $(\% / y r)$ & NA & 15.0 \\
Inflation rate $(\% / y r)$ & 0 & 0 \\
Marginal income tax rate $(\%)$ & NA & 34.0 \\
NA - not applicable. & & \\
NOTE: Debt and equity return rates are real, net of inflation.
\end{tabular}

The costs of closure and post-closure activities are assumed to be financed from investment of amounts collected as a revenue component in the unit disposal charge.

The only revenue sources available are assumed to be:

- The total unit disposal charges collected during the operating period

- Interest income on any funds that are deposited for future expenses, such as closure and post-closure costs.

3.3.1.4 Unit Disposal Charge Cost Components. The level unit disposal cost was developed by considering these key contributing cost components: 
- Pre-operational costs

- Equipment costs

- Operating period annual expenses

- Closure period annual expenses

- Post-closure period annual expenses.

By presenting these key contributing cost components separately in the various cases, it is considerably easier to review the effects of changes, relationships, and relative importance of the various key components.

3.3.1.5 Unit Disposal Charge Present Value Computation. The present value of unit disposal charge was computed for the base case and alternate cases by developing a computerbased financial model with components addressing each of the contributing components of unit disposal charge. The financial model has the capability to represent both the public and private financing options, as well as the combined public/private financing option. Overall, the unit disposal charges were developed on a revenue requirements basis, whereby such charges would recover all necessary life-cycle costs, including taxes.

Pre-operational costs are capitalized in all cases. The pre-operational period costs are assumed to be financed using $100 \%$ interim debt financing with capitalized interest. The capitalized pre-operational costs are then recovered over the operating period amortized on a straight line basis, through the level unit disposal charge. The interest rate on the pre-operational period interim financing was assumed to be the public cost of debt for all cases. Costs of private equity return on outstanding equity, as well as for annual interest costs on outstanding public and private debt, are recovered through the level unit disposal charge. All debt and equity investments are assumed to be amortized straight line to zero over the operating period. Tax depreciation of pre-operational costs is assumed to be straight line to zero over the operating period, and is only applicable to the privately capitalized portion of the investment.

Equipment acquisition costs are assumed to be incurred at initiation of the opcration period and are assumed to be capitalized and amortized over the equipment's expected useful life, straight line to zero. No residual value was assumed for used equipment since the equipment would potentially have zero market value because of its use in radioactive waste handling operations. Equipment was assumed to be replaced at the end of its useful life. Ownership of and investment in equipment and recovery of the associated capital costs and taxes was treated the same as pre-operational capitalized costs. Tax depreciation was assumed to be straight line to zero over the useful life of the equipment.

Annual operating costs during the operating period were recovered as expense items. There was no capitalization of annual operating expense assumed for financial or tax purposes. The annual costs for cell construction were treated as operating expenses for tax purposes since the source of revenue attributable to the cells was the revenue received in the same year that such cells were constructed and filled. 
Site closure costs were treated as expenses incurred in each of the closure period years. These costs were recovered by computing a level unit disposal charge cost component which, when collected over the operating period and invested over the operating and closure periods, would provide sufficient funds to pay the annual closure period costs. It was assumed that the interest income on this investment fund would be taxable to the extent that private ownership existed in the base case and appropriate alternates. The unit disposal charge was calculated to recover necessary tax payments during both the operational period and the site closure period. The contributions to the principal in the closure fund, which were collected in the unit disposal charge during the operating period, were assumed to be deferred for tax purposes to the closure period where all such contributions were used for expenses and thus, were non-taxable.

Post-closure costs were treated as expenses in each of the post-closure period years. The post-closure costs were recovered by computing a level unit disposal charge component cost, which when collected over the operating period and invested over the operating, closure, and post-closure periods, would provide sufficient funds to pay the annual post-closure period costs. It was assumed that there would not be private ownership during the post-closure period; therefore, it was assumed that contributions to the post-closure investment fund and the interest on such fund, would not be taxable.

The cost of public debt was used as the discount rate for all present value computations in order to compare the case results on a common basis. The rate used to compute interest earned through the investment of closure and post-closure funds was also the public cost of debt.

3.3.1.6 Selection of Debt Interest Rates and Equity Return Rates. The key financial parameters selected for the base case are shown in Table 3-19. For this report, real annual rates of return for interest on debt and return on equity were used, and these real rates were net of inflation.

A principal purpose of this report is to analyze cost differences attributable to certain design, operating, and ownership parameters for a small volume LLW disposal facility. The interest rate and equity rate of return are important variables when considering financing for long-lived operations. Clearly, this is the case with this study because the total base case time period evaluated considering the pre-operational period, operating period, closure period, and postclosure period is 141 years. Specific interest rate and inflation projections over such extremely long time horizons are highly dependent on a number of assumptions and variables. In order to maintain the focus on comparison of alternatives, this study limited the uncertainty associated with such long-range projections by using real interest rates, which measure only the interest rate above inllation.

Two reference sources for historical long-term interest rates and inflation rates in the United States (U.S.) were evaluated for this study and are discussed below.

S.C. Leuthold ${ }^{10}$ analyzed 188 years of U.S. long-term interest rates (high quality securities) and rates of inflation and deflation for the period from 1792 to 1979. The average real rate of interest for long-term instruments was found to be $3.34 \%$. However, Leuthold made it clear that real long-term interest rates were quite variable and ranged from a positive $17 \%$ to a negative $18 \%$ over the period. For reference, positive real interest rates are obtained when actual interest 
rates are above the rate of inflation. Leuthold's findings are particularly interesting since he used a three-year moving average smoothing technique. Thus, one can expect that year to year changes in real interest rates would show even more variability.

P.C. Spiro ${ }^{11}$ analyzed real interest rates in the U.S. over the period 1890 to 1986 . Spiro considered long-term U.S. Government bond yields and inflation/deflation. Spiro's findings appear comparable to those of Leuthold, although presented somewhat differently. In particular, Spiro's work demonstrated the high volatility of inflation rates on a year to year basis and thus, the volatility of real interest rates.

Because this study focuses primarily on evaluating the sensitivity of the facility cost and unit disposal charge to certain changes in facility design, facility operations, and ownership parameters, it was necessary to select a basic long-term real interest rate to be used consistently for all cases. In addition, in reviewing historical U.S. interest rate data, it must be noted that the base case and the alternate cases have overall project lives ranging from 131 to 151 years. A further point is that it is assumed in this report that the public agency involved would not be the Federal government; thus, it could be expected that the interest rates applicable to such public agency would be higher than those for U.S. government bonds.

Therefore, for this report, a long-term real annual interest rate of $4 \%$ on public agency debt was used for the base case. However, to test the impact of alternate real annual rates, values of $1 \%$ and $7 \%$ for public agency debt were selected for sensitivity analysis in order to allow comparison of the impact of variations in real interest rates on unit disposal charges.

Private enterprise funding and ownership were considered for the base case with $50 \%$ public agency ownership and 50\% private enterprise ownership, as well as alternate cases for $100 \%$ private enterprise ownership and $100 \%$ public ownership in the sensitivity analysis. Detailed development of how the private enterprise ownership would be structured and the related financing arrangements are beyond the scope of this study. However, the assumptions made are:

- The private enterprise was financially strong and would have to pay long-term interest rates only 100 basis points above the public agency debt cost. The use of the basis points $(1 / 100$ of a percent) is included to clarify the relationship between different rates of interest. For example, if public agency debt has a $4 \%$ interest rate, the private enterprise debt would have an interest rate of $5 \%$, or 100 basis points higher than the public agency debt.

- The pre-operational period costs were assumed to be $100 \%$ financed with a project financing arrangement using $100 \%$ debt and capitalized interest (the interest rate is assumed to be equal to the public agency debt rate).

- In cases having private enterprise ownership, the private enterprise would participate in ownership during the pre-operational, operational, and closure phases in the percentage amounts applicable to the particular sensitivity study case.

- The private enterprise would not have an ownership role during the long-term postclosure period in any of the cases examined. 
- The ownership structure and participation of the private enterprise would have relatively lower levels of business risk; thus, an after-tax annual return on equity investment of $15 \%$ was selected and measured on a real interest basis, net of inflation.

- At the end of the pre-operational period, and immediately prior to the start of the operation period, the full amount of the pre-operational debt would be paid off and replaced with permanent financing. The permanent financing would consist of all debt for the public agency ownership portion, and debt and equity for the private enterprise ownership portion. All permanent financing debt principal amounts are assumed to be amortized straight line to zero over the facility operating period.

3.3.1.7 Business Issues. As a business matter, variability in real interest rates will have a direct effect on the unit disposal charge. The funding structure contemplated in this report assumes that waste generators will pay a one-time charge to dispose of the waste, and will then have no further financial liability. The liabilities and responsibilities to operate the facility, close the facility, and conduct maintenance and monitoring during the post-closure period would be the responsibility of the facility owners.

Two components of the unit disposal charge are quite dependent on the projected real interest rate because the costs for these components are incurred far in the future and paid from principal collected during the operations period and the interest earnings thereon. Those components are:

- Closure period cost

- $\quad$ Post-closure period cost.

The unit disposal charge is calculated assuming that interest bearing investment funds are established using revenue from portions of the unit disposal charge to pay for the closure and post-closure costs, when such actions eventually occur. A critical assumption is the real rate of interest to be earned by deposits to these funds. From a business perspective, risks that such funds might be inadequate to cover the final expenses, due to inadequate interest income, would clearly be factored into the pricing for these components because the costs for these components are incurred far in the future from the start of pre-operations. It should be anticipated that the owners of the facility may desire to apply contingency to interest rate earnings assumptions by assuming lower rates of real interest and thus, causing the unit disposal charges to be higher because the unit disposal charge cost components for closure and post-closure costs would increase with lower interest rates.

In addition, the concept of trust type funds with projected lives ranging up to 145 years will require legal review. There are various statutes containing rules against perpetuities (for example, trusts with lives more than 90 years), although there may be exemptions for governmental agencies.

Business and risk sharing structures other than investment trusts funded from a one-time unit disposal charge could be examined, including concepts for later assessments on waste generators to make up fund deficiencies, and take-or-pay contracts. These would reduce risk by 
assuring the facility owners and lenders of adequate cash flow to meet projected obligations, regardless of the actual amount of waste disposed or the interest earnings actually realized.

\subsubsection{Results - Unit Disposal Cost Analysis, Base Case}

The cost components of the unit disposal charge for the base case are presented in Table 3-20. The cost recovery items and financial analysis procedures are discussed in detail in Section 3.3.1. All cases assume that disposal charges are paid by waste sources (i.c., waste generators) only during the operations period and that no other revenues are available, except for interest income on the funds for closure and post-closure costs.

Table 3-20 is organized so that the contribution to the unit disposal charge by each cost element occurring during the project life cycle is shown separately. The first column, Cost Recovery Item, presents five separate cost components as follows:

- Pre-operations investment. This component comprises the recovery for all costs that are incurred prior to the start of operation. The pre-operations investment (including interest on the investment) is capitalized and recovered over to the operating period.

- Equipment investment. This component comprises the cost recovery for all capitalized construction equipment acquired for operating purposes. Investment in equipment is assumed to occur at the start of the operations period, and to be repeated every 10 years during the operating period.

- Annual operating expense. This component comprises the cost recovery needed to recover annual operating expenses during the operating period.

- Site closure. This component comprises the cost recovery needed to pay for the expenses to be incurred in the closure period. These costs are funded from the unit disposal charge collected during the operating period and from interest earned on those funds.

- Post-closure operations. This component comprises the eost recovery needed to pay for the expenses to be incurred in the post-closure period. These costs are funded from the unit disposal charge collected during the operating period, and from interest earned on those funds.

The data columns in Table $3-20$ present the following information:

- Total present value cost at start of pre-operations period. This cost is the annual cost recovery dollar amount needed for each cost recovery item and is eomputed for each year of the operating period. The total present value of all annual cost recovery amounts is computed and totalled, as of the start of the pre-operational period (assumed to be 1992), and presented in 1992 dollars.

- Annual requirement operations period. The annual requirement is the present value at the start of the pre-operational period, in 1992 dollars, of a level annual 
payment that would need to be recovered in each year of the operating period in order to pay for the particular cost recovery item.

- Unit disposal charge. The unit disposal charge represents, for each cost recovery item, the present value at the start of pre-operations, in 1992 dollars, of the level amount that would need to be collected for each cubic foot of waste deposited in the facility. For each cost recovery item, the annual requirement (Column 3) is divided by the annual disposal rate for the particular case (in cubic feet per year) to obtain the unit disposal charge. The unit disposal charges for each cost recovery item are totalled to obtain the total unit disposal charge.

Table 3-20. Unit disposal charge-base case.

\begin{tabular}{lccr}
\hline \multicolumn{1}{c}{ Cost recovery item } & $\begin{array}{c}\text { Total present value } \\
\text { at start of pre- } \\
\text { operations period }(\$)\end{array}$ & $\begin{array}{c}\text { Operations period } \\
\text { annual } \\
\text { requirement }(\$)^{\mathrm{a}}\end{array}$ & $\begin{array}{r}\text { Unit disposal } \\
\text { charge }\left(\$ / \mathrm{ft}^{3}\right)^{\mathrm{a}}\end{array}$ \\
\hline Pre-operations investment & $55,042,929$ & $3,183,138$ & 106.10 \\
Equipment investment & $3,737,048$ & 216,114 & 7.20 \\
Annual operations expense & $50,876,040$ & $2,942,166$ & 98.07 \\
Site closure & $4,490,890$ & 259,709 & 8.66 \\
Post-closure operations & $2,051,255$ & 118,624 & 3.95 \\
TOTAL & $116,198,163$ & $6,719,751$ & 223.99 \\
& & & \\
\hline
\end{tabular}

\subsection{Sensitivity Analysis}

A sensitivity analysis was conducted to evaluate the impact of changes in selected variables. The variables and associated values used for both the base case and sensitivity analysis are summarized in Table 3-21. The specific parameter values for the base case and for each of the alternate cases are presented in Table 3-22.

The parameters to be varied for the sensitivity analysis were chosen to demonstrate a range of conditions, all of which could be expected to vary depending on site specific circumstances. Two additional parameters were selected for initial study, but abandoned after the first round of modeling because these parameters had an impact of less that $1 \%$ on the unit disposal charge. The first of these was the post-closure care period. The length of the post-closure period was felt to potentially have a significant effect on the unit disposal charge. This parameter was evaluated by varying the post-closure period from a 100 -year period to a 300 - and 500 -year period for a sensitivity analysis. While this change obviously impacted the total estimated cost, very little impact was seen on the unit disposal charge. This relative insensitivity is attributed to the 
Table 3-21. Summary of variables and values.

\begin{tabular}{lccc}
\hline Variable name & $\begin{array}{c}\text { Base case } \\
\text { value }\end{array}$ & Alternate cases & Alternate cases \\
\hline $\begin{array}{l}\text { Waste receipt } \\
\text { rate }\end{array}$ & $30,000 \mathrm{ft}^{3} /$ year & $10,000 \mathrm{ft}^{3} /$ year & $50,000 \mathrm{ft}^{3} / \mathrm{year}$ \\
Operating life & 30 years & 20 years & 40 years \\
$\begin{array}{l}\text { Financing } \\
\text { source }\end{array}$ & $50 \%$ public & $100 \%$ private & $100 \%$ public \\
Interest rate & $50 \%$ private & & $7 \%$ \\
\hline
\end{tabular}

devaluing effect of compound interest rates on expenditures far in the future as occurs when using the present value method. This is further attributed to the use of an interest bearing fund to finance the post-closure period. W'hen using the interest rates selected for this study, only a small amount of additional dollars are required in the fund to last 500 years rather than 300 years (as measured by present value cost in 1992). A post-clorure period of 100 years was selected for the base case after the sensitivity analysis of this parameter was dropped because a post-closure care period of 100 years is consistent with present regulatory requirements and, therefore, is most applicable to user needs.

The second parameter selected for initial study, but dropped from the sensitivity analysis, was the operating season. The base case value of two months was varied between one month and three months. This parameter also produced very little impact on the unit disposal charge because the incremental labor required to place waste in the cell is only $3.3 \%$ of the total cost for the operations period and an even smaller portion of the life-cycle cost. Consequently, variations impacting the labor requirements for waste placement will have a small effect on the total cost because this variable cost is small in comparison to the relatively large fixed costs associated with site operations. These fixed costs are constant over the waste receipt rates used for this study.

Waste receipt rate, operating life, source of linancing (i.e., public or private), and interest rate are the sensitivity analysis parameters included in this report. These parameters are realistic in the sense that they can be expected to vary depending on disposal facility parameters, ownership structure, and financial circumstances. Variations in both the waste receipt rate and operating life impact not only the operating costs, but also the pre- operations costs because variations in these parameters result in a different total disposal volume. This was achieved by changing the cost of engineering and construction to reflect the construction of a facility of the appropriate size. Changes in financing source and interest rate led to variations in the unit disposal charge components attributable to all phases of operations.

The results of the sensitivity analysis are tabulated in Sections 3.4.1 through 3.4.4. The tables showing unit disposal charge for each alternate case are organized using the same row and column data as used for the base case. For reference, Section 3.3.2 provides explanations of the row and column headings, and the content of the columns. 


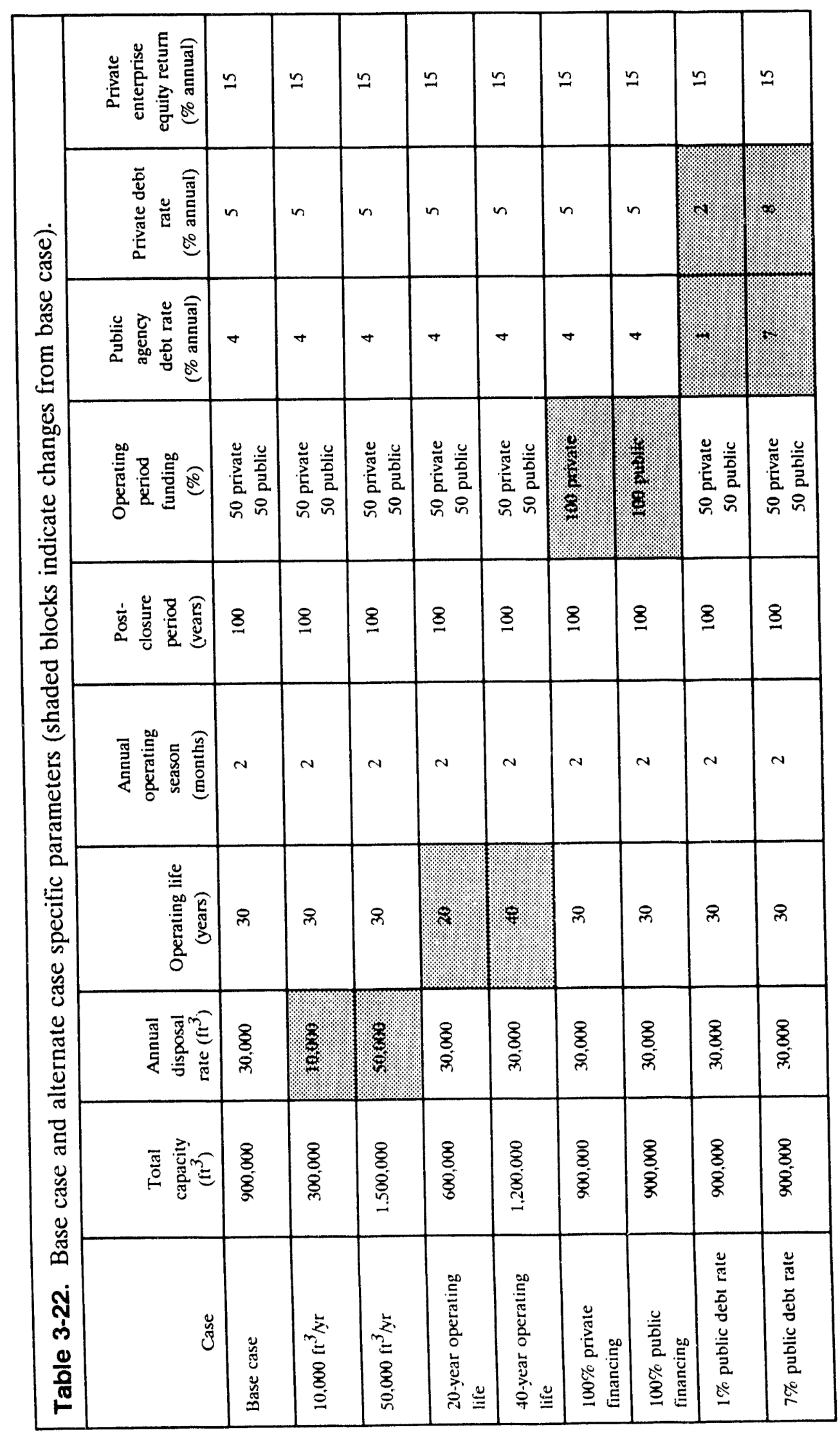




\subsubsection{Variation in Disposal Facility Waste Receipt Rate}

The waste receipt rate was varied for the sensitivity analysis from the value of $30,000 \mathrm{ft}^{3}$ per year used in the base case to a low value of $10,000 \mathrm{ft}^{3}$ per year and a high value of $50,000 \mathrm{ft}^{3}$ per year. The greatest impact to the unit disposal charges occurs because of the change in the volume of waste over which the investment can be distributed. A lesser impact is attributed to the changes in annual operating expense resulting from changes in total disposal facility capacity (and associated cell construction cost) from a low of $300,000 \mathrm{ft}^{3}$ to a high of $1,500,000 \mathrm{ft}^{3}$. The change in disposal facility capacity is attributable to holding the operating period constant at 30 years while varying the waste receipt rate. No change was made in the size of the waste disposal crew used to place the waste because the base case staff provides one person for each required position and no changes were deemed appropriate for this analysis.

Tables 3-23 and 3-24 summarize the results of the sensitivity analysis. The unit cost varies from the base case value of $\$ 223.99$ to a low of $\$ 140.14\left(50,000 \mathrm{ft}^{3}\right.$ per year) and a high of $\$ 643.27\left(10,000 \mathrm{ft}^{3}\right.$ per year $)$.

Table 3-23. Unit disposal charge- $10,000 \mathrm{ft}^{3}$ per year.

\begin{tabular}{|c|c|c|c|}
\hline Cost recovery item & $\begin{array}{l}\text { Total present } \\
\text { value at start of } \\
\text { pre-operations } \\
\text { period }(\$)\end{array}$ & $\begin{array}{l}\text { Operations } \\
\text { period annual } \\
\text { requirement } \\
(\$)^{\mathrm{a}}\end{array}$ & $\begin{array}{c}\text { Unit disposal } \\
\text { charge } \\
\left(\$ / \mathrm{rt}^{3}\right)^{\mathrm{a}}\end{array}$ \\
\hline Pre-operations investment & $54,006,071$ & $3,123,176$ & 312.32 \\
\hline Equipment investment & $3,737,048$ & 216,114 & 21.61 \\
\hline Annual operations expense & $46,949,160$ & $2,715,075$ & 271.51 \\
\hline Site closure & $4,490,890$ & 259,709 & 25.97 \\
\hline Post-closure operations & $2,051,255$ & 118,624 & 11.86 \\
\hline TOTAL & $\$ 111,234,424$ & $\$ 6,432,698$ & $\$ 643.27$ \\
\hline
\end{tabular}

a. Present value.

\subsubsection{Variation in Operating Life}

The facility operating life was varied for the sensitivity analysis from the value of 30 years used in the base case to a low value of 20 years and a high value of 40 years. The waste receipt rate was held constant at the hase case value of $30,000 \mathrm{ft}^{3}$ per year, resulting in disposal facilities with capacities of $600,000 \mathrm{ft}^{3}$ for the 20-year operating period and $1,200,000 \mathrm{ft}^{3}$ for the 40 -year operating period. The greatest impact to the unit disposal charges attributable to this change occurs because of the change in the volume of waste over which the investment can be 
Tahle -24. Unit disposal charge $-50,000 \mathrm{ft}^{3}$ per year.

\begin{tabular}{|c|c|c|c|}
\hline Cost recovery item & $\begin{array}{c}\text { Total present } \\
\text { value at start of } \\
\text { pre-operations } \\
\text { period }(\$\end{array}$ & $\begin{array}{l}\text { Operations period } \\
\text { annual } \\
\text { requirement }(\$)^{\mathrm{a}}\end{array}$ & $\begin{array}{l}\text { Unit disposal } \\
\text { charge }\left(\$ / \mathrm{ft}^{3}\right)^{\mathrm{a}}\end{array}$ \\
\hline $\begin{array}{l}\text { Pre-operations } \\
\text { investment }\end{array}$ & $56,079,787$ & $3,243,100$ & 64.86 \\
\hline Equipment investment & $3,737,048$ & 216,114 & 4.32 \\
\hline $\begin{array}{l}\text { Annual operations } \\
\text { expense }\end{array}$ & $54,802,920$ & $3,169,258$ & 63.39 \\
\hline Site closure & $4,490,890$ & 259,709 & 5.19 \\
\hline Post-closure operations & $2,051,255$ & 118,624 & 2.37 \\
\hline TOTAL & $\$ 121,161,901$ & $\$ 7,006,805$ & $\$ 140.14$ \\
\hline
\end{tabular}

a. Present value.

distributed. Therc is no inpact on annual operating expense resulting from changes in disposal facility capacity because the waste receipt rate remained unchanged from the base case.

Tables 3-25 and 3-26 summarize the results of the sensitivity analysis. The disposal unit charge varies from the br se case value of $\$ 223.99$ to a low of $\$ 211.34$ (40-year operating life) to a high of $\$ 2.53 .47$ (20-year operating life).

\subsubsection{Variation in Source of Financing}

The source of financing was varied between public and private sources from an even division in the base case to $1 \% \%$ private in the first case and $100 \%$ public in the second. This impacted the cost of all project phases for a number of reasons, all of which tended to increase the cost when private financing was used:

- Taxes: Private revenue is subject to tax

- Return on investinent: Frivate operators require a return on their investment greater than the interest rate paid on debt

- Interest differential: Private debt incurs a higher interest rate. 
Table 3-25. Unit disposal charge-20-Year operating life.

\begin{tabular}{|c|c|c|c|}
\hline Cost recovery item & $\begin{array}{c}\text { Total present value at } \\
\text { start of pre-operations } \\
\text { period }(\$)\end{array}$ & $\begin{array}{l}\text { Operations period } \\
\text { annual } \\
\text { requirement }(\$)^{\mathrm{a}}\end{array}$ & $\begin{array}{l}\text { Unit disposal } \\
\text { charge }\left(\$ / \mathrm{ft}^{3}\right)^{\mathrm{a}}\end{array}$ \\
\hline $\begin{array}{l}\text { Pre-operations } \\
\text { investment }\end{array}$ & $51,045,773$ & $3,756,037$ & 125.20 \\
\hline Equipment investment & $2,937,058$ & 216,114 & 7.20 \\
\hline Tperations & $40,044,974$ & $2,946,579$ & 98.22 \\
\hline Site ¿losure & $6,277,813$ & 461,932 & 15.40 \\
\hline Post-closure operations & $3,036,359$ & 223,421 & 7.45 \\
\hline TOTAL & $\$ 103,341,976$ & $\$ 7,604,083$ & $\$ 253.47$ \\
\hline
\end{tabular}

a. Present value.

Table 3-26. Unit disposal charge-40-year operating life.

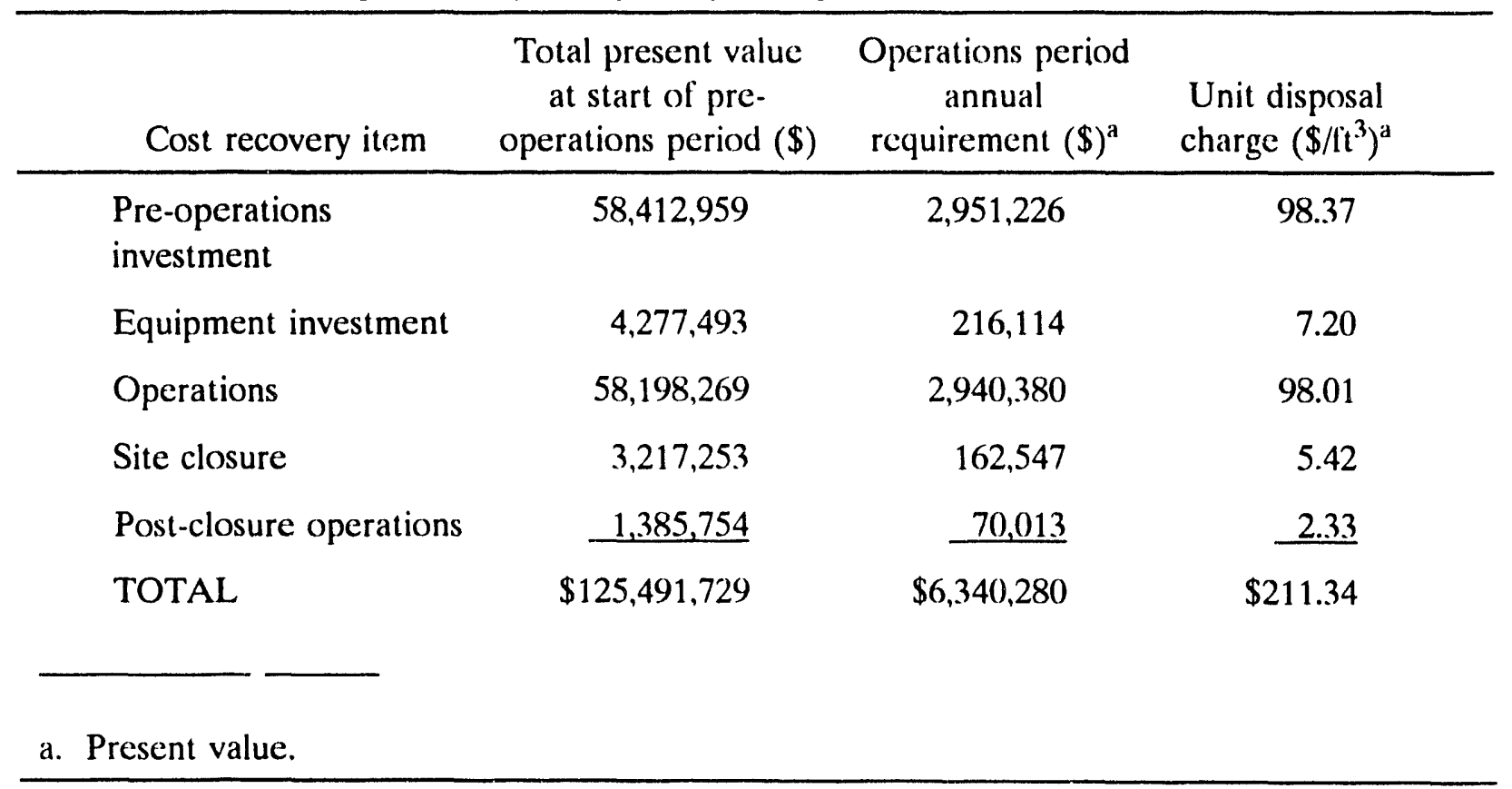

Tables 3-27 and 3-28 summarize the results of the sensitivity analysis. The unit disposal charge varies from the base case value of $\$ 22.3 .99$ to a low of $\$ 195.08$ (100\% public financing) and to a high of $\$ 252.94$ for $100 \%$ private financing. Clearly, public financing with $100 \%$ borrowed funds results in a lower unit disposal charge. 
Table 3-27. Unit disposal charge-100\% private financing.

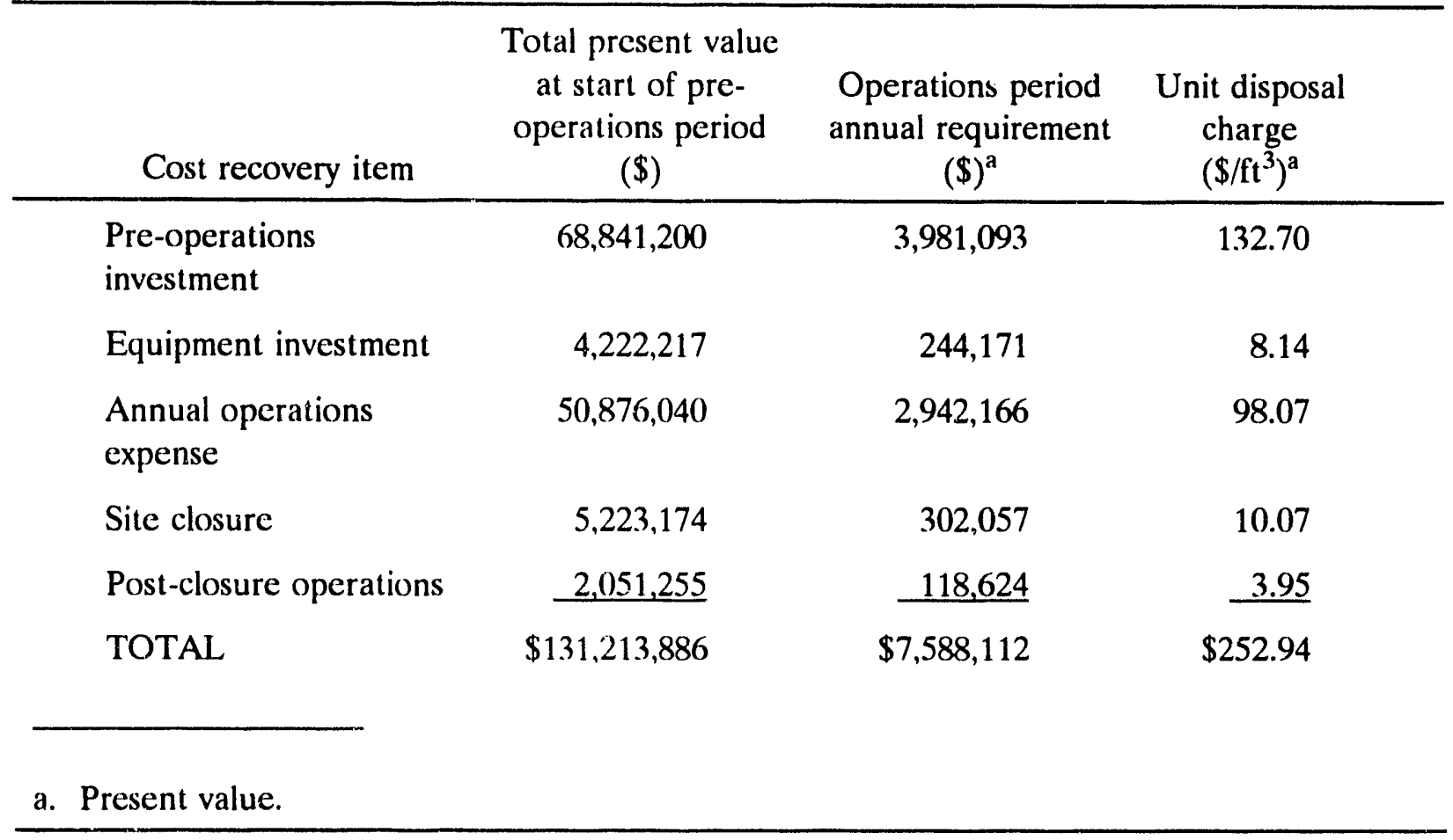

Table 3-28. Unit disposal charge-100\% public financing.

\begin{tabular}{lccc}
\hline \multicolumn{1}{c}{ Cost recovery item } & $\begin{array}{c}\text { Total present value } \\
\text { at start of } \\
\text { pre-operations } \\
\text { period }(\$)\end{array}$ & $\begin{array}{c}\text { Operations } \\
\text { period annual } \\
\text { requirement }(\$)^{\mathbf{a}}\end{array}$ & $\begin{array}{c}\text { Unit disposal } \\
\text { charge }\left(\$ / \mathrm{ft}^{3}\right)^{\mathbf{a}}\end{array}$ \\
\hline $\begin{array}{l}\text { Pre-operations } \\
\text { investment }\end{array}$ & $41,244,659$ & $2,385,183$ & 79.51 \\
$\begin{array}{l}\text { Equipment investment } \\
\text { Annual operations }\end{array}$ & $3,251,880$ & 188,057 & 6.27 \\
expense & $50,876,040$ & $2,942,166$ & 98.07 \\
Site closure & $3,777,265$ & 218,440 & 7.28 \\
Post-closure operations & $2,051,255$ & 118,624 & 3.95 \\
TOTAL & $\$ 101,201,099$ & $\$ 5,852,470$ & $\$ 195.08$
\end{tabular}

a. Present value. 


\subsubsection{Variation in Interest Rates}

The annual rate of interest on public agency debt was varied from the base case value of $4 \%$, to values of $1 \%$ and $7 \%$. Consistency with respect to the interest rate for private enterprise debt was maintained by retaining the 100 basis point difference between private and public debt interest rates. Thus, the annual rate of interest for private enterprise debt varied from $2 \%$ to $8 \%$, respectively.

Discounting for present value was performed using the same procedure as in all other cases where the discount rate for present value calculations equals the public agency debt rate. Thus, the discount rate varied between $1 \%$ and $7 \%$, respectively.

The results of these variations in interest rates are shown in Tables 3-29 and 3-30.

Table 3-29. Unit disposal charge-1\% per year public agency debt rate.

\begin{tabular}{lccr}
\hline \multicolumn{1}{c}{ Cost recovery item } & $\begin{array}{c}\text { Total present value at } \\
\text { start of pre-operations } \\
\text { period }(\$)\end{array}$ & $\begin{array}{c}\text { Operations period } \\
\text { annual requirement } \\
(\$)^{\mathrm{a}}\end{array}$ & $\begin{array}{r}\text { Unit disposal } \\
\text { charge }\left(\$ / \mathrm{ft}^{3}\right)^{\mathrm{a}}\end{array}$ \\
\hline Pre-operations investment & $64,937,891$ & $2,516,221$ & 83.87 \\
Equipment investment & $5,899,450$ & 228,593 & 7.62 \\
Annual operations expense & $90,082,253$ & $3,490,517$ & 116.35 \\
Site closure & $11,798,625$ & 457,174 & 15.24 \\
Post-closure operations & $17,013,089$ & $\underline{659,225}$ & 21.97 \\
TOTAL & $\$ 189,731,309$ & $\$ 7,351,730$ & $\$ 245.06$ \\
& & & \\
\hline
\end{tabular}

The post-closure component of the unit disposal charge is impacted most, on a percentage basis, by the change in interest rates since this component deals with costs far in the future. Reducing the discount rate from the base case value of $4 \%$ to $1 \%$ causes the present value (expressed in 1992 dollars) to increase substantially because decreasing the discount rate reduces the impact of time on the value of future expenditures. This is demonstrated in Table 3-29, where the post-closure component of the unit disposal charge increases from the base case value of $\$ 3.95$ per $\mathrm{ft}^{3}$ to $\$ 21.97$ per $\mathrm{ft}^{3}$. Additionally, a reduction in the interest rate also raises the cost components for the closure and post-closure periods because less interest income will be earned on the investment funds to pay for these cost components. Consequently, the total unit disposal charge increases from the base case value of $\$ 223.99 \mathrm{per}^{3} \mathrm{t}^{3}$ to $\$ 245.06$ per $\mathrm{ft}^{3}$.

The relative insensitivity of the unit disposal charge to increases in the public debt rate is demonstrated in Table 3-30. In this case, raising the interest rate to 7\% causes the contribution 
of post-closure operations to the unit disposal charge to decrease from the base case value of $\$ 3.95$ to $\$ 1.03$.

Table 3-30. Unit disposal charge-7\% per year public agency debt rate.

\begin{tabular}{lccr}
\hline \multicolumn{1}{c}{ Cost recovery item } & $\begin{array}{c}\text { Total present value At } \\
\text { start of pre-operations } \\
\text { period }(\$)\end{array}$ & $\begin{array}{c}\text { Operations period } \\
\text { annual requirement } \\
(\$)^{\mathrm{a}}\end{array}$ & $\begin{array}{r}\text { Unit disposal } \\
\text { charge }\left(\$ / \mathrm{ft}^{3}\right)^{\mathrm{a}}\end{array}$ \\
\hline Pre-operations investment & $48,549,688$ & $3,912,445$ & 130.41 \\
Equipment investment & $2,533,866$ & 204,195 & 6.81 \\
Annual operations expense & $90,948,394$ & $2,494,020$ & 83.13 \\
Site closure & $1,766,485$ & 142,355 & 4.75 \\
Post-closure operations & 382,956 & 30,861 & 1.03 \\
TOTAL & $\$ 84,181,388$ & $\$ 6,783,875$ & $\$ 226.13$ \\
& & & \\
\hline
\end{tabular}

The values and relationships of the other components of the unit disposal charge also vary from the base case because of the interest rate and discount rates, but the degree of change is less pronounced. These variations are less pronounced for costs incurred in earlier phases because less time elapses between the start of the project and the point where the cost is incurred. It is to be noted that the results of the two interest rate variation cases indicate a minimum value for total unit disposal charge occurs in the interest rate range selected for the base case. Lowering and raising the interest rate on public agency debt both cause increases in total unit disposal charge. However, the effect is caused by the interplay of the interest rates and the discount rate, as well as the particular characteristics of each component cost of the unit disposal charge.

In summary, the effect on unit disposal charge of raising the interest rate from $4 \%$ to $7 \%$ is less significant than the effect of lowering the interest rate from $4 \%$ to $1 \%$. This result means that the larger the post-closure period costs are, the greater the impact will be from lowering the interest rate. 


\section{SUMMARY}

The results of the unit disposal charge analysis for the base case and each altcrnative examined in the sensitivity analysis are summarized in Table 4-1, and are expressed in present value dollars per cubic foot.

Table 4-1. Unit disposal charge summary $\left(\$ / \mathrm{ft}^{3}\right)$.

\begin{tabular}{|c|c|c|c|c|c|}
\hline Case & $\begin{array}{l}\text { Pre-operational } \\
\operatorname{cost}^{\mathrm{a}}\end{array}$ & $\begin{array}{c}\text { Operational } \\
\cos ^{\mathrm{a}}\end{array}$ & $\begin{array}{c}\text { Closure } \\
\operatorname{cost}^{a}\end{array}$ & $\begin{array}{c}\text { Post-closure } \\
\operatorname{cost}^{\mathrm{a}}\end{array}$ & $\begin{array}{c}\text { Total unit } \\
\text { disposal } \\
\text { charge }^{\mathrm{a}}\end{array}$ \\
\hline Base case & 106.10 & 105.27 & 8.66 & 3.95 & $\$ 223.99$ \\
\hline $10,000 \mathrm{ft}^{3} / \mathrm{yr}$ & 312.32 & 293.12 & 25.97 & 11.86 & $\$ 643.27$ \\
\hline $50,000 \mathrm{ft}^{3} / \mathrm{yr}$ & 64.86 & 67.71 & 5.19 & 2.37 & $\$ 140.14$ \\
\hline $\begin{array}{l}\text { 20-year operating } \\
\text { life }\end{array}$ & 125.20 & 105.42 & 15.40 & 7.45 & $\$ 253.47$ \\
\hline $\begin{array}{l}\text { 40-year operating } \\
\text { life }\end{array}$ & 98.37 & 105.21 & 5.42 & 2.33 & $\$ 211.34$ \\
\hline $\begin{array}{l}100 \% \text { private } \\
\text { financing }\end{array}$ & 132.70 & 106.21 & 10.07 & 3.95 & $\$ 252.94$ \\
\hline $\begin{array}{l}100 \% \text { public } \\
\text { financing }\end{array}$ & 79.51 & 104.34 & 7.28 & 3.95 & $\$ 195.08$ \\
\hline $\begin{array}{l}1 \% \text { public debt } \\
\text { rate }\end{array}$ & 83.87 & 123.97 & 15.24 & 21.97 & $\$ 245.06$ \\
\hline $\begin{array}{l}7 \% \text { public debt } \\
\text { rate }\end{array}$ & 130.41 & 89.94 & 4.75 & 1.03 & $\$ 226.13$ \\
\hline
\end{tabular}




\section{REFERENCES}

1. Design Report Alternative Concepts for Low Level Radioactive Waste Disposal, June 1987.

2. U.S. Nuclear Regulatory Commission, Standard Review Plan for the Review of a License Application for a Low-Level Radioactive Waste Disposal Facility, NUREG-1200, January 1987.

3. U.S. Nuclear Regulatory Commission, Standard Format and Content of a License Application for a Low-Level Radioactive Waste Disposal Facility, NUREG-1199, January 1987.

4. U.S. Nuclear Regulatory Commission, Domestic Licensing of Production and Utilization Facilities, Appendix B, "Quality Assurance Criteria for Nuclear Power Plants and Fuel Reprocessing Plants," Code of Federal Regulations, Title 10, Part 50.

5. American National Standards Institute/American Society of Mechanical Engineers, Requirements for Auditing of Quality Assurance Programs for Nuclear Power Plants, ANSI/ASME N45.2.12, 1977.

6. American Society of Mechanical Engineers Quality Assurance Requirements for Nuclear Facilities, ANSI/ASME NQA-1-1986 edition.

7. U.S. Nuclear Regulatory Commission, Quality Assurance Guidelines for a Low-Level Radioactive Waste Disposal Facility, NUREG 1293, Revision 1, April 1991.

8. Federal Register, 56 FR 23360, "Standards for Protection Against Radiation," U.S. Nuclear Regulatory Commission, May 21, 1991.

9. Federal Register, 57 FR 21216, "Standards for Protection Against Radiation; Extension of Implementation Date," U.S. Nuclear Regulatory Commission, May 19, 1992.

10. S. C. Leuthold, "Interest Rates, Inflation, and Deflation," Financial Analysts Journal, January-February 1981, pgs. 28-41.

11. P. S. Spiro, Real Interest Rates and Investment and Borrowing Strategy, Quorum Books, 1989. 


\section{Appendix A}

Site, Facility, and Operating Description 


$$
\text { A-2 }
$$




\section{Appendix A}

\section{Site, Facility and Operating Description}

\section{A.1 SITE}

Because no actual site is considered for this effort, it is impossible to provide information for all of the site characteristics required for design or license application. This section presents basic site, facility, and operating data used to develop the conceptual design developed for this study. Land requirements are summarized in Table A-1. Assumed structural conditions at the generic site, needed for structural analyses of the different disposal concepts, are tabulated in Table A-2.

Table A-1. Land requirements.

\begin{tabular}{lc}
\hline \multicolumn{1}{c}{ Parameter } & Requirement \\
\hline Site dimensions (buffer zone) & $1,714 \times 1,288 \mathrm{ft}$ \\
Total site area & 51 acres \\
Disposal area & 15 acres \\
\hline
\end{tabular}

Many other types of information must be obtained in the characterization of any real site to meet regulatory guidelines such as those described in the U.S. Nuclear Regulatory Commission's (NRC's) standard review plans, ${ }^{2}$ the NRC's Standard Format and Content Guide, ${ }^{3}$ and the requirements of good engineering practice. Detailed information of this type is beyond the scope of this report.

\section{A.1.1 Land Requirements}

The disposal facility is rectangular in shape with an access road connecting the main gate to the nearest road and requires approximately 51 acres of land, as presented in Table A-1. The configuration of the structures within the buffer zone could be rearranged from that assumed for this report to take advantage of a site with a different orientation or one possessing natural features that impact facility arrangements.

The facility is surrounded by a fence that defines the outer limit of the buffer zone. The buffer zone separates the outer fence from the disposal area. This zone includes those facilities that do not involve radiological operations, such as the administration building, guard house, and concrete batch plant. The buffer zone also includes the surface retention basin and the cover material storage area, since these involve nonradiological operations as well. The waste receiving and inspection building, waste storage building, equipment storage building, and general warehouse are all located on the line separating the buffer zone from the waste disposal area. The truck wash occupies the roadway section that provides access to the waste disposal area. 
Table A-2. Structural design criteria.

Characteristics

Disposal unit service life (yr)

Soil bearing capacity $\left(\mathrm{lb} / \mathrm{ft}^{2}\right)$

Coefficient of friction against sliding

Modules of subgrade reaction $\left(\mathrm{lb} / \mathrm{in}^{3}\right)$

Permeability of cover system ( $\mathrm{ft} / \mathrm{yr}$ )

Soil weight in cover system $\left(\mathrm{lb} / \mathrm{ft}^{3}\right)$

Ground snow load $\left(\mathrm{lb} / \mathrm{ft}^{2}\right)$

Construction load $\left(\mathrm{lb} / \mathrm{ft}^{2}\right)$

Base wind load (mph)

Tornado wind speed (mph)

Earthquake maximum acceleration (g)

Aircraft impact load (lb/ft $\left.{ }^{2}\right)$

Backfill compaction
Assumption

500

4,400

0.4

100

220

110

50

150

70

360

0.11

600

or 100 kips over

$25 \mathrm{ft}^{2}$ greater of $95 \%$

modified Proctor or

$85 \%$ relative density

Dry backfill equivalent liquid density

- $\quad$ Sandy gravel $\left(\mathrm{lb} / \mathrm{ft}^{3}\right)$

$30-40$

- $\quad$ Sandy clay $\left(\mathrm{lb} / \mathrm{ft}^{3}\right)$

40

- $\quad$ Clay $\left(\mathrm{lb} / \mathrm{ft}^{3}\right)$

50

Moist backfill equivalent liquid density $\left(\mathrm{lb} / \mathrm{ft}^{3}\right)$

The waste disposal area encloses two rows of above-grade concrete vaults: one for Class A waste and one for Class $\mathrm{B} / \mathrm{C}$ waste. When filled, these vaults will be covered by a single earth cover tor permanent closure.

\section{A.1.2 Land Improvements and Utilities}

The general arrangement of land improvements, buildings, and other structures is shown in Figure A-1 and described in this section. 

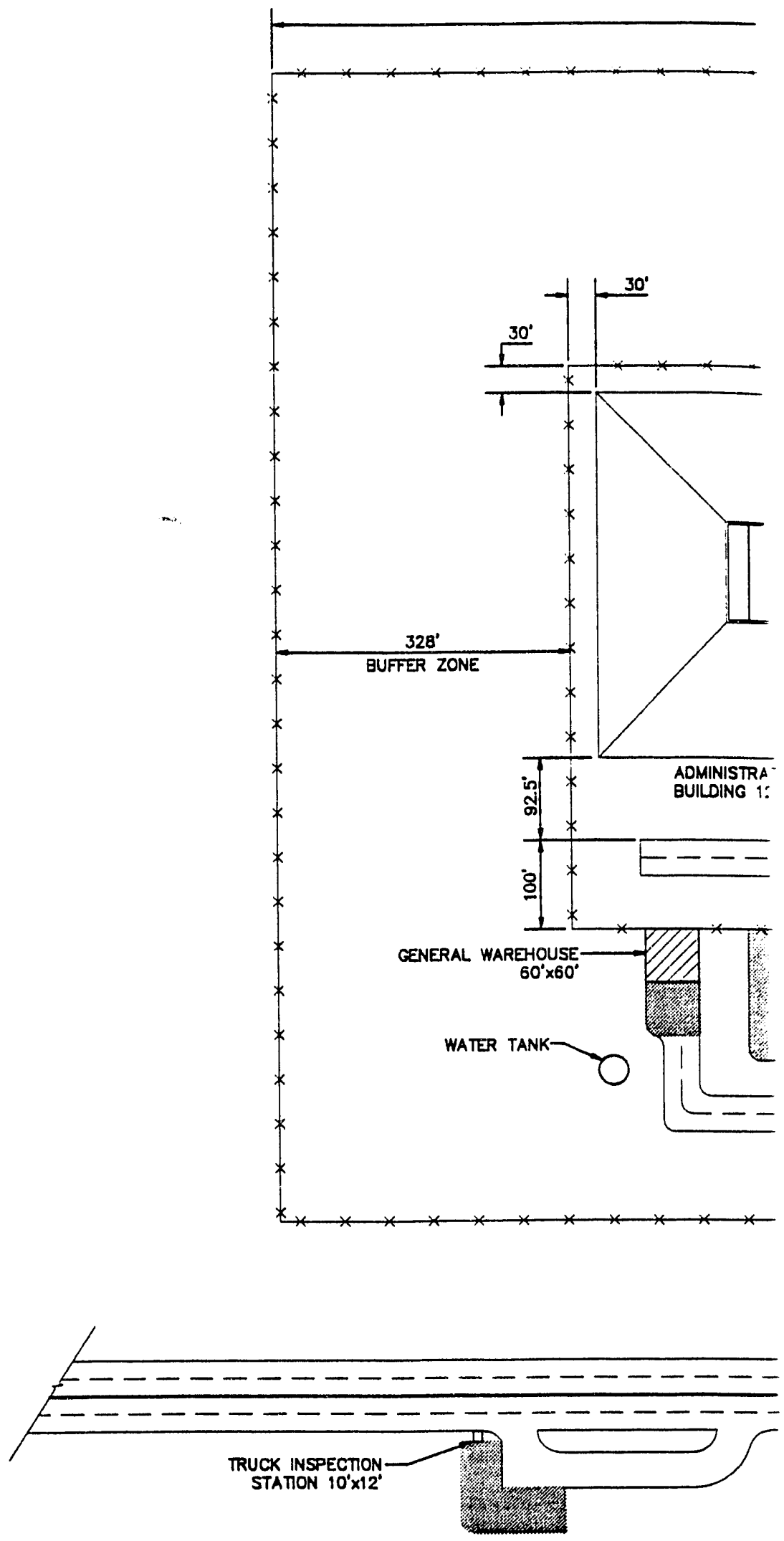

Figure A-1. Small-volume low-level radioactive waste disposal facility disposal site general arrangement. 
- Site. The site is rectangular in shape and is enclosed by a perimeter fence that delines the buffer zonc. The bulfer zone extends a minimum of $328 \mathrm{ft}$ from the perimeter lence to the fence enclosing the waste disposal area, and is established to limit access by the public. The bulfer zone will be cleared of trees and shrubs with only grasses allowed to remain, and will be graded away from the waste disposal area with the resultant flow collected in a retention basin. Uncontaminated tlows from points within the waste disposal area will also be discharged to the retention basin. The waste disposal area is aiso enclosed by a lence and includes the vaults for both Class $A$ and Class $\mathrm{B} / \mathrm{C}$ waste.

- Roads. A five-mile-long access road is provided to connect the site to the nearest public road. This road will be a two-lane (one lane in each direction), undivided road with a 4-in. asphalt concrete surface and a 12-in. base course. Roads located within the buffer zone and the disposal area will be of the same design and will provide access to all buildings in the buffer zone, and to the waste disposal area.

- Fencing. The entire site is encircled by a single 8-ft-tall chain link fence, and is accessed through a gate located at the front of the disposal facility with access controlled by a security guard as shown in Figure A-1. A second, inner fence encircles the waste disposal area and isolates it within the buffer zone. A gate allows passage between the buffer zone and the waste disposal area through the truck wash.

- $\quad$ Site utilities. The site will be provided with water, power, sanitary sewer, telecommunications, and tire alarm utilities. Power and telecommunications will be extended to the site from a point of connection five miles from the site. Sanitary sewer service will be provided with a septic tank and leach tield located on site. Potable water will be provided from a point of connection located five miles from the site, with peak and fire demands met from an onsite storage tank of 5,000-gal capacity. Storage tanks will be provided for containment of potentially contaminated wash waste produced by decontamination operations and the truck wash, and dedicated storage tanks will be provided for fuel and industrial liquid waste. Potentially contaminated water will be collected, monitored, and treated if found to be contaminated. Uncontaminated water will be discharged to onsite surface retention basins. 
$708^{\circ}-6^{\prime \prime}$
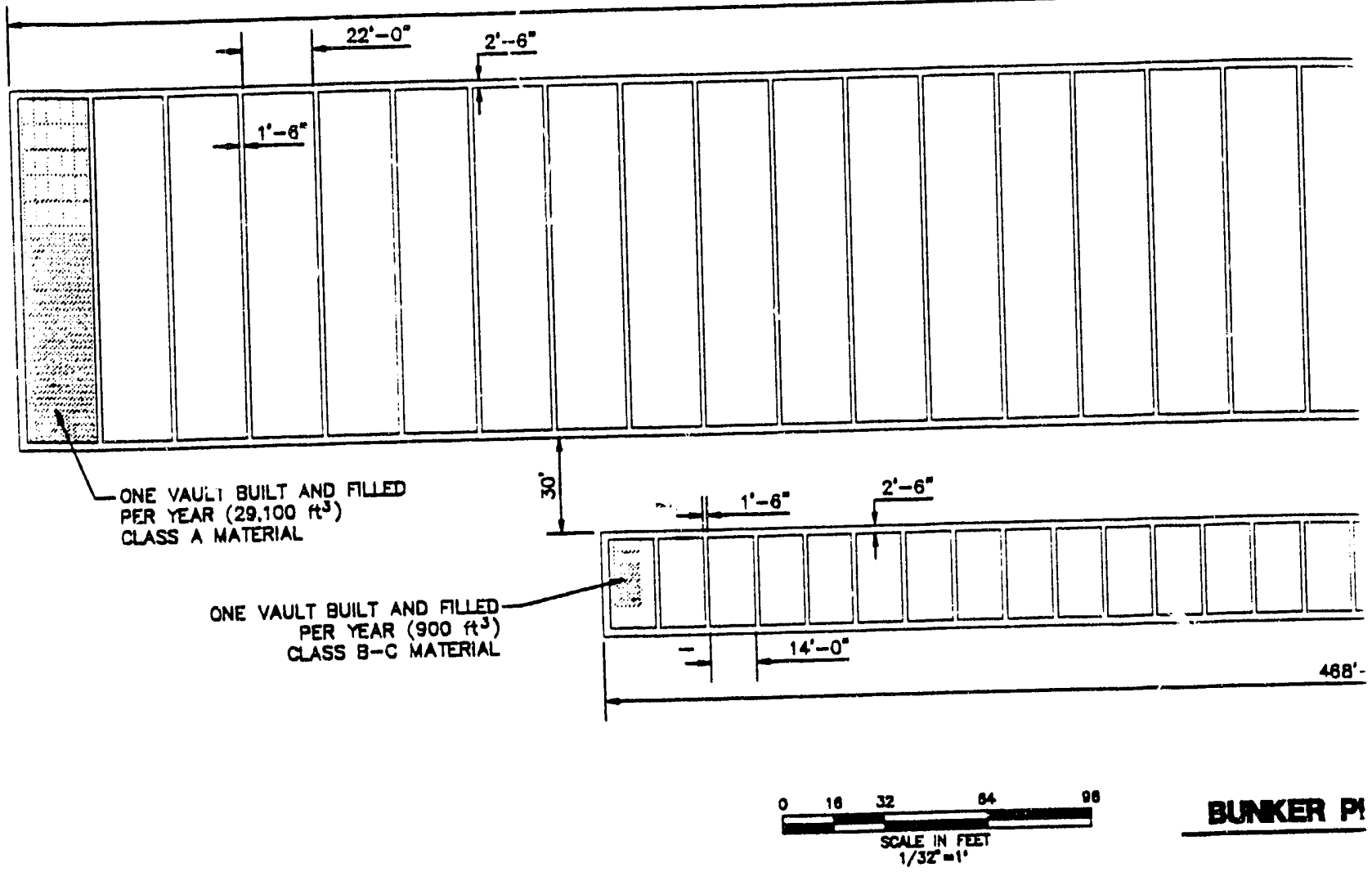

BUNKER P

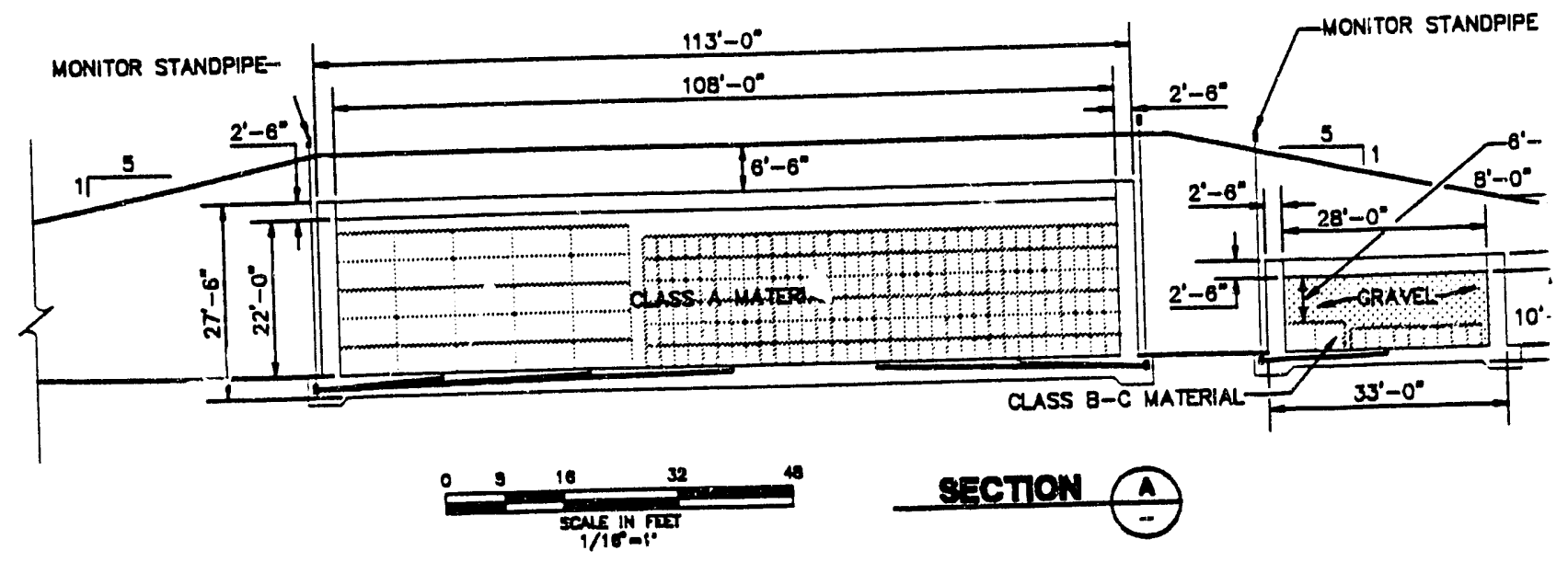

Figure A-2. Small-volume low-level radioactive waste disposal facility disposal cell plan and section. 


\section{A.2 FACILITY DESCRIPTION}

The disposal facility design is based on assumed critcria for structural design, as well as compliance with applicable codes and standards.

\section{A.2.1 Design Criteria}

The structural design criteria in Table A-2 are those used to develop the disposal facility design.

\section{A.2.2 Codes and Standards}

National codes and standards listed in this section are representative of the requirements for the disposal facility. In addition, design, operation, closure, and post-closure maintenance of LLW disposal sites must also comply with state and local codes and standards. No attempt has been made to identify any typical state or local requirements for this study.

- U.S. Occupational Safety and Health Administration (OSHA) regulations and standards:

- 29 CFR 1910, "Occupational Safety and Health Siandards"-all suhparts except Subparts $\mathrm{R}$, and $\mathrm{T}$ through $\mathrm{Z}$.

- 29 CFR 1926, "Safety and Health Regulations for Construction"-all subparts.

- 10 CFR 61, U.S. Nuclear Regulatory Commission, "Licensing Requirements for Land Disposal of Radioactive Waste."

- American Concrete Institute, "Code Requirements for Nuclear Safety Related Concrete Structures (ACI 349-80)," ACI Manual of Concrete Practice, Part 4-1992.

- The Amcrican National Standards Institute/Amcrican Society of Civil Engineers document, Minimum Design Loads for Buildings and Other Structures (ANSI/ASCE 7; 1988).

- The following parts of the 1993 edition of the Uniform Building Code:

Part I: $\quad$ Administrative, all chapters

Part II: $\quad$ Definitions and Abbreviations, all chapters

Part III: $\quad$ Requirements Based on Occupancy, Chapters 5 and 7

Part IV: $\quad$ Requirements Based on Type of Construction, all Chapters 
Part V: $\quad$ Engineering Regulations - Quality and Design of the Materials of Construction, all chapters except Chapters 25 and 28

Part VI: $\quad$ Detailed Regulations, all chapters except Chapters 34 through 37, 39 , and 40

Part VII: $\quad$ Fire Resistive Standards for Fire Protection, all chapters

Part IX: Wall and Ceiling Coverings, chapter 47

Part X: $\quad$ Special Subjects, Chapters 50 and 54

Part XI: $\quad$ UBC Standards, Chapter 60

Appendix: $\quad$ Chapters 35,55 , and 70 .

- The following parts of the 1991 edition of the Uniform Mechanical Code:

$\begin{array}{ll}\text { Part I: } & \text { Administrative } \\ \text { Part II: } & \text { Definitions and Abbreviations } \\ \text { Part III: } & \text { Heating, Ventilating, and Cooling } \\ \text { Part V: } & \text { Miscellaneous } \\ \text { Appendix A: } & \text { UMC Standards } \\ \text { Appendix B: } & \text { Piping } \\ \text { Appendix C: } & \text { System Sizing Standards. }\end{array}$

- The following parts of the 1993 edition of the National Electric Code:

$\begin{array}{ll}\text { Chapter 1: } & \text { General } \\ \text { Chapter 2: } & \text { Wiring and Protection } \\ \text { Chapter 3: } & \text { Wiring Methods and Materials } \\ \text { Chapter 4: } & \text { Equipment for General Use } \\ \text { Chapter 5: } & \text { Special Occupancies } \\ \text { Chapter 6: } & \text { Special Equipment } \\ \text { Chapter 7: } & \text { Special Conditions } \\ \text { Chapter 8: } & \text { Communications Systems. }\end{array}$

- The American Association of Highway and Transportation Officials (AASHTO) specifications contain sections that are applicable to the design and construction of access roads, bridges, and culverts to and within a disposal site. Utility roadways within the site that will not bear heavy loads are excluded from these requirements.

\section{A.2.3 Support Facilities}

Support facilities are provided to house personnel, operations, and equipment at the disposal site. Nine buildings are shown on Figure A-1 and are described in the following paragraphs. 
- Truck inspection station. The truck inspection station is used for the initial inspection of the vehicles transporting the waste and is located along the access road, outside of the buffer zone. The structure is a simple, single story kiosk of approximately $120 \mathrm{ft}^{2}$ in area. The building utilities include power, lighting, fire alarm, water, and telecommunications. The structure will be a prefabricated unit constructed of insulated metal paneling over a metal frame, and installed on a prepared foundation consisting of a slab on grade with utility connections. A paved area will be provided adjacent to the truck inspection station so that trucks can pull off of the main road for inspection.

- Guard station. The guard station is located at the front gate and controls access to the buffer zone. The structure is a simple, single story kiosk of approximately $120 \mathrm{ft}^{2}$ in area. The building utilities include power, lighting, fire alarm, water, and telecommunications. The structure will be a prefabricated unit constructed of insulated metal paneling over a metal frame, and will be installed on a prepared foundation consisting of a slab on grade with utility connections.

- Truck wash. The truck wash will be located past the guard station at the entrance to the waste disposal area, and provides an enclosed facility for truck cleaning. The building will be constructed of metal pancls installed over a structural stecl frame with a clear height of $20 \mathrm{ft}$. The foundation will be perimeter stem wall and spread footing, and the floor will be a depressed slab on grade to collect wash water. Fixed and manual nozzles will be used to wash the trucks and a drain system will collect all liquid for storage in a tank. Uncontaminated liquid will be discharged, and contaminated liquid will be retained and treated as waste. Utilitics will include power, water, telecommunications, fire protection, lïre alarm, and liquid waste collection.

- Concrete batch plant. A permanent concrete batch plant will be located within the buffer zone to provide a source of concrete for support facility construction, cell construction, cell cover construction, and a source of sand and gravel for cell backfill. The plant will be installed on a 40 by 100 -ft concrete slab with a spot footing foundation to support concentrated loads from the batch plant supports. Utilities will include power, water, telecommunications, fïre protection, and fire alarm.

- General warehouse. The general warehouse will store all bulk material, spare parts, concrete forms, and other supplies needed at the site. The building will be approximately $3,600 \mathrm{ft}^{2}$ in area, and will be constructed of insulated metal panels installed over a structural steel frame with a clear height of $20 \mathrm{ft}$. The foundation will be a perimeter stem wall and spread looting, and the filoor will be a slab on grade. Utilities will include power, water, telecommunications, fire protection, and fire alarm.

- Waste receiving and inspection building. The waste receiving and inspection building provides a loading dock and other facilities for receiving trucks loaded with waste, removing the waste containers from the trucks, inspecting waste containers, and decontaminating the exterior of the waste containers if needed. The building will be approximately $10,000 \mathrm{ft}^{2}$ in area and will be constructed of insulated metal panels installed over a structural steel frame. The foundation will be a perimeter stem wall 
and spread footing, and the floor will be a slab on grade. The building includes an interior bay constructed with walls of shielding concrete to reduce worker exposure to containers with high levels of gamma radiation. Utilities will include power, water, telecommunications, fire protection, and fire alarm.

- Waste storage building. The waste storage building allows waste to be stored temporarily while awaiting placement in the vault. Although normal operations call for waste to be placed immediately in a disposal cell within the vault, there may be circumstances when this is not possible because of weather or other interference. This building is sized to store $30,000 \mathrm{ft}^{3}$ of waste, or one year's volume at the planned rate. The building will be approximately $30,000 \mathrm{ft}^{2}$ in area and will be constructed of metal panels installed over a structural steel frame with a clear height of $14 \mathrm{ft}$. The foundation will be a perimeter stem wall and spread footing, and the floor will be a slab on grade. The building includes an interior bay constructed with walls of shielding concrete to reduce worker exposure to containers with high levels of gamma radiation. Utilities will include power, water, telecommunications, fire protection, and fire alarm.

- Equipment storage building. The equipment storage building provides a covered storage area for the rolling stock and other equipment permanently located at the site. This building includes fucl storage and dispensing facilities for diesel- and gasolinepowered equipment, as well as minor maintenance supplies, tools, and parts. The building will be approximately $5,625 \mathrm{ft}^{2}$ in area and will be constructed of insulated metal panels installed over a structural steel frame with a clear height of $20 \mathrm{ft}$. The foundation will be a perimeter stem wall and spread footing, and the floor will be a slab on grade. Utilities will include power, water, telecommunications, fire alarm, fire protection, and sewer. Storage tanks will be provided for industrial and potentially hazardous liquid waste generated as a result of maintenance operations.

- Administration building. The administration building will house all onsite staff, including waste operations, safety, management, and security. The building exterior will be constructed of metal panels installed over a structural steel frame with a clear height of $10 \mathrm{ft}$. Interior surfaces will be finished with gypsum wallboard and a suspended acoustical ceiling. Interior partitions will be constructed of gypsum wallboard over metal studs. The foundation will be a perimeter stem wall and spread footing, and the floor will be a slab on grade. Floor surfaces will be covered with carpet in office areas and tile in entry, high traffic, and bathroom areas. Utilities will include power, water, telecommunications, fire alarm, fire protection, and sewer.

\section{A.2.4 Disposal Systems}

Class $A$ waste is placed in a separate vault from that used for Class $B$ and $C$ waste (10 CFR61.7(b)(2)). This separate placement of the Class B and C waste ensures stability of the more concentrated waste and, additionally, minimizes water exposure to such waste and minimizes exposure of potential intruders to such waste. In addition, this separation minimizes occupational exposure of operating personnel to the higher radiation levels associated with Class $\mathrm{B}$ and $\mathrm{C}$ waste, and limits the impact of higher radiation levels on operating productivity. Figure A-2 
presents a plan and section of the cellular vaults designed for both Class $A$ and Class $B / C$ waste. The earthen cover used for final closure of vaults for all classes of waste includes a provision for a minimum of $6.5 \mathrm{ft}$ of earthen cover material.

\section{A.2.4.1 Disposal System for Class A Waste}

The salient features of the Class $\mathrm{A}$ waste disposal system are:

- The waste is emplaced in a cellular concrete vault constructed at existing grade, with dimensions listed in Table A-3

- The cells are sized to accommodate one year of Class $\mathrm{A}$ waste at the forecast rate of $29,100 \mathrm{ft}^{3}$ per year ( $97 \%$ of $30,000 \mathrm{ft}^{3}$ per year)

- The voids between the waste containers within the cells are filled with structural till of clean sand

- When filled, the cells are closed with a concrete, cast-in-place lid

- When the facility reaches the end of its operating life, the concrete vault will be covered with an earthen cover.

Table A-3. Class A disposal vault dimensions.

\begin{tabular}{ll}
\hline Parameter & Dimensions \\
\hline Number of cells & 30 \\
Base dimensions & $22 \times 108 \mathrm{ft}$ \\
Cell height & $20 \mathrm{ft} 6 \mathrm{in.}$ \\
Gross cell vo!lume & $48,708 \mathrm{ft}^{3}$ \\
\hline
\end{tabular}

The concrete vaults are designed to withstand the effects of corrosion over an extended period through the application of conservative design practices. One failure mechanism for concrete is corrosion of the reinforcing steel, which carries the tensile load applied to the reinforced concrete. The potential for corrosion can be limited through adjustment of concrete design specifications to reduce permeability, thereby inhibiting chemical attack, and by increasing the thickness of concrete cover between the reinforcing bars and the exposed face of the concrete. Increasing the thickness, or cover, protecting the reinforcing bars from the environment increases the protection from corrosion by increasing the distance that dissolved material must travel through concrete to react with the steel. Provision for limiting the potential for corrosion has also been made through the addition of a drainage system and monitoring standpipes for the collection and removal of any water that may enter the disposal cell. 
The concrete vault consists of a series of large, reinforced concrete cells with vertical walls. Each cell is sized to accommodate a combination of drums, boxes, and cask liners using the projected mix of containers identified in Table A-10. The cells will be constructed by excavating the existing soil to a depth of $5 \mathrm{ft}$ and placing $2.5 \mathrm{ft}$ of gravcl to support the floor of the cell. The cell floor will be sloped slightly to provide positive drainage to a french drain constructed of permeable gravel. These drain systems are designed to operate even after the cell is closed and can be monitored through standpipes that zxtend above the cell and, eventually, above the earth cover.

Each cell will be filled with waste and then capped with a cast-in-place, reinforced concrete lid. The lid is cast directly over the sand backfill that surrounds the waste in the cell and provides continuous support to the lid. Each cell will be closed with a lid as the cell is filled and there will be construction joints between sections of the lid. These joints will be constructed to facilitate thermal expansion and contraction while providing for a leak resistant design.

Temporary protection to prevent entry of moisture into the open cell will be implemented by using a temporary cover of polyethylene or similar heavy plastic sheeting, or heavier tarpaulin type materials as appropriate, over a temporary metal or wood framework. These temporary methods may be augmented by constructing the permanent concrete lid in sections as the cell is filled.

A portable crane will be used to lift the waste into the cell for placement. Waste will be placed into the cell until it is filled to the design capacity. The cell dimensions were established to accommodate the desired volume of waste and include a 2-ft contingency to allow clearance for variations in waste package dimensions and to lacilitate the addition of sand as fill. When the cell is ready for closure, the remaining vertical space, approximately $2 \mathrm{ft}$, will be filled with sand to support the lid.

An earth cover will be constructed over the cells when the facility is closed. The earth cover is discussed in detail in Section A.2.5.

\section{A.2.4.2 Disposal System for Class B/C Waste}

The salient features of the Class $\mathrm{B} / \mathrm{C}$ waste disposal system are:

- The waste is emplaced in a cellular concrete vault constructed at existing grade, with dimensions listed in Table A-4

- The cells are sized to accommodate one year of waste at the forecast rate of 900 $\mathrm{ft}^{3}$ per year

- The voids between the waste containers are filled with structural fill material

- The cells are filled to within $6.5 \mathrm{ft}$ of the cell top, and the balance of the cell volume is filled with gravel for shiclding

- When filled, the cells are closed with a concrete, cast-in-place lid 
- When the facility reaches the end of its operating life and is filled, the concrete vault will be covered with an earthen cover.

The Class $\mathrm{B} / \mathrm{C}$ cell is similar to the Class $\mathrm{A}$ cell in all design respects except for the cell volume and the 6.5-ft. layer of gravel.

Table A-4. Class $B / C$ disposal vault dimensions.

\begin{tabular}{lc}
\hline \multicolumn{1}{c}{ Parameter } & Measurement \\
\hline Number of cells & 30 \\
Base dimensions & $14 \times 28 \mathrm{ft}$ \\
Cell height & $10 \mathrm{ft} 6 \mathrm{in.}$ \\
Gross cell volume & $4,116 \mathrm{ft}^{3}$ \\
\hline
\end{tabular}

\section{A.2.5 Earth Cover}

Multi-layered earthen cover systems are used to provide a permanent cover over the concrete vaults after the end of the operating period. A cross-section of the cover is shown in Figure A-3 and a cross-section of the vault with cover is shown in Figure A-2.

A major function of the cover system is to serve as a low permeability barrier that provides a preferential path by which water can be directed away from disposal units and that restricts the rate at which percolating water infiltrates into the disposal units. The cover system also serves to restrict human, plant, or animal intrusion into the waste and to reduce gamma exposure rates at the surface of the disposal unit to acceptable levels.

The cover system will consist of alternating layers of materials such as clay, sand, gravel, cobble, boulders, rip-rap, and/or topsoil with native vegetation established. Each of these components of the cover system has a particular function. These functions include acting as a moisture barrier (clay), moisture conduit for shedding water that has infiltrated through layers above (sand or gravel), intrusion barrier (cobble or boulders), growth medium for vegetation (topsoil), and providing resistance to erosion (cobble, boulders, rip-rap, topsoil covered with vegetation).

It is reasonable to include synthetic moisture barricrs in the design of the cover systems in an effort to supplement their performance characteristics. It is doubtful, however, that there are sulficient data and information about the behavior of these materials over the long term and hence, there is doubt that their successful function beyond a few years or perhaps decades could be justified in the licensing process. Therefore, the cover design proposed for evaluation in this report does not rely upon these materials for the cover systems.

The proposed earth-covered concrete vault design incorporates an earthen cover approximately $6.5 \mathrm{ft}$ thick over the top of the Class A waste vault, as shown in Figure A-2, and as detailed in Figure A-3. 


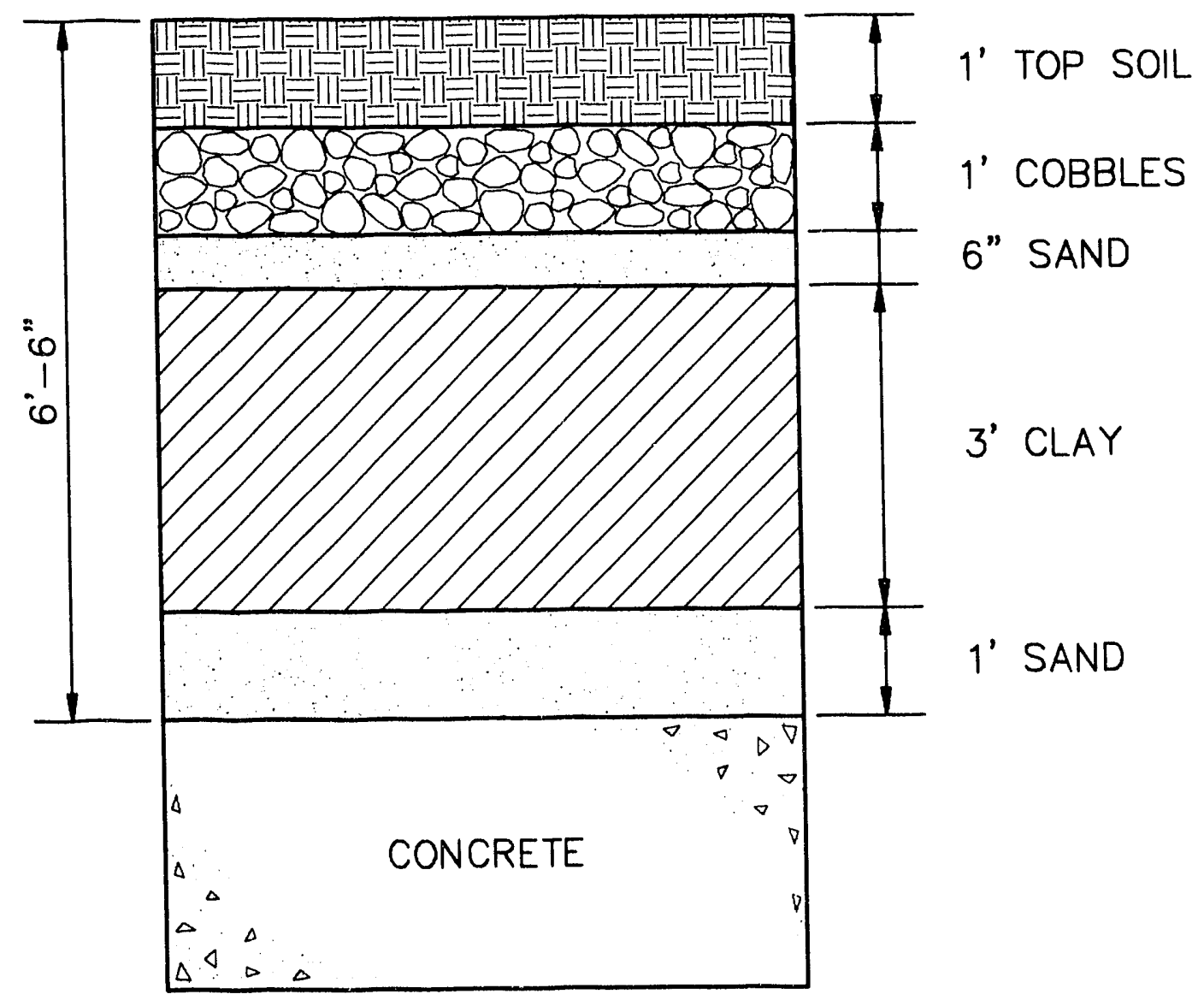

Figure A-3. Earth cover section. 
The proposed cover and vault design for Class $\mathrm{B} / \mathrm{C}$ waste incorporates several layers and types of materials over the top of the Class B/C waste, with a total thickness of at least $16.5 \mathrm{ft}$ $(5 \mathrm{~m})$, as shown in Figure A-2. The requirements for the intruder barrier required by $10 \mathrm{CFR}$ 61.52(a)(2) are as follows:

Wastes designated as Class $C$ pursuant to 61.55 , must be disposed of so that the top of the waste is a minimum of 5 meters below the top surface of the cover or must be disposed of with intruder barriers that are designed to protect against an inadvertent intrusion for at least 500 years.

and pertains only to Class $\mathrm{C}$ waste. In the proposed earth-covered concrete vault design, the above requirements are both met, under the assumptions of this report, because the 2.5 -ft-thick concrete vault is assumed to provide the required intruder protection for at least 500 years, and the Class $\mathrm{C}$ waste is a minimum of $5 \mathrm{~m}$ below the top surface of the overall cover.

\section{A.2.6 Minimizing Effects of Subsidence}

All waste containers will be deliberately positioned to facilitate the filling of void spaces between containers, and these spaces will be filled before each cell is closed with a concrete lid. Although the concrete lid is designed to be self-supporting, the lid will rest on and derive additional support from the waste itself. Proper compaction of the earth cover and the final slope of 1:5 (rise:run) will reduce the potential for subsidence or slumping of the earth cover.

Experience has shown that problems with earthen covers, such as subsidence, generally become evident in the first few years after the cover is put in place. Following the initial construction of the earth cover, any subsidence will be rectified by placing additional cover material. Placement of the additional material will continue until subsidence has ceased or is not likely to occur in the foreseeable future. The cover must be stabilized before the state assumes responsibility for long-term care.

\section{A.2.7 Environmental Monitoring}

An environmental monitnring program must provide data for pre-construction characterization, construction and operation monitoring, and closure and post-closure surveillance [10 CFR 61.7(c)(3) and (4)]. This program must be adequate to provide data to evaluate the potential health and environmental impacts during construction and operation of the facility and to enable the evaluation of long-term effects and the need for mitigative measures. The program must be capable of providing early warning of releases of radionuclides from the disposal site before they leave the site boundary [10 CFR 61.53(c) and (d)]. The disposal facility design relies on a buffer zone to provide the necessery delay in groundwater migration necessary to implement mitigative actions, if necessary.

The environmental monitoring program must assess all exposure pathways to onsite and offsite persons to ensure that contaminant concentrations not only meet the performance criteria for exposure levels, but also actively implement the concept of maintaining exposure as low as reasonably achievable. Initially, the goal of the environmental monitoring program is to provide 
detection monitoring. This monitoring is to detect any contaminant release from the facility. During the operation, closure, and post-closure periods, release of radionuclides from the facility is not anticipated to occur. However, if positive detection of environmental contaminants does occur, the monitoring program would then become a compliance monitoring program, with increased sampling, laboratory analyses, and data analysis in excess of the levels indicated in this monitoring program and estimate. Data analysis for either type of environmental monitoring program would include both comparison analysis (comparison of uncontaminated sample sites with those potentially contaminated from facility releases), and time series analysis (detecting changes in contaminant concentrations caused by facility releases, at a single sampling site over a period of time).

The environmental monitoring program is described in two parts. The phased environmental monitoring program is presented in Section A.2.7.1 and indicates the type of monitoring tests, and the number and frequencies of tests, for each of the four project phases. Section A.2.7.2 presents the analysis methods and descriptions of each type test to be performed.

\section{A.2.7.1 Phased Environmental Monitoring Program}

Environmental monitoring will be performed throughout the pre-operations, operations, closure, and post-closure phases, but at significantly differing levels. Monitoring during the preoperations phase is necessary to establish a baseline against which to compare operations results; operations phase monitoring is necessary to detect disposal activity related or immediate release of contaminants to the onsite or offsite environment; monitoring for immediate releases will continue during the closure period; post-closure period monitoring will detect any long-term releases from the disposal facility.

The data presented in Tables A-5, A-6, A-7, and A-8 define the type, number, frequency, and analyses necessary for the environmental monitoring program during all four phases of the facility life. The numbers of samples identified in the tables for each of the respective phases represent the desired number of valid test samples for each test type. The actual quantity of samples will be increased by approximately $20 \%$ to provide for duplicates, blanks, spikes, and other sampling requirements associated with quality assurance and quality control.

The components of the gross, specific, anion, volatile, and semivolatiles analyses are common to all tables in Section 3 and Appendix A of this report, and are as follows:

- Gross - Gross alpha, gross beta, and gamma spectroscopy

- $\quad$ Specific - Am-241, Np-237, Pu-238, 239/240, U-234, U-235, U-238, Ra-226, Ra-228, C-14, Ni-63, Tc-99, Sr-90, I-129, Cs-137, and H-3

- Anions - $\mathrm{NO}_{3}, \mathrm{NO}_{2}{ }^{=}, \mathrm{Cl}^{-}, \mathrm{SO}_{4}{ }^{=}, \mathrm{CO}_{3}{ }^{=}$, and $\mathrm{PO}_{4}{ }^{-3}$

- Volatile - Target compound list (TCL) volatile organics

- Semivolatiles - TCL semivolatile organics. 
Table A-5. Pre-operations one-time sampling program.

\begin{tabular}{llllll}
\hline \multicolumn{1}{c}{$\begin{array}{c}\text { Environmental } \\
\text { medium }\end{array}$} & Type & Number & Frequency & $\begin{array}{c}\text { Radiological } \\
\text { analyses }\end{array}$ & $\begin{array}{c}\text { Chemical } \\
\text { analyses }\end{array}$ \\
\hline External gamma & $\begin{array}{l}\text { Ground } \\
\text { survey }\end{array}$ & One time & Initial & Gamma & \\
Soil & $\begin{array}{l}\text { Drilling } \\
\text { core }\end{array}$ & 25 & One time & Gross & $\begin{array}{l}\text { TAL metals, } \\
\text { volatile, } \\
\text { semivolatiles, } \\
\mathrm{CN}^{-}\end{array}$ \\
\hline
\end{tabular}

A.2.7.1.1 Pre-Operations Environmental Monitoring Program. Environmental monitoring during the pre-operations phase will consist of one-time sampling activities, and initial baseline data collection One-time sampling, to include the initial external gamma ground survey and sampling of drilling cores collected during site characterization and construction, will be collected as these operations occur during the pre-operations phase.

Baseline environmental monitoring will be performed during the one-year period prior to the anticipated commencement of operations. This environmental sampling will include the full operations phase environmental monitoring program, and will include quarterly sampling and analysis for those samples that are to be monitored on an annual basis in the operation period program, as shown in Table A-6. This quarterly sampling will provide a four-sample baseline, where annual sampling would only provide one sample result.

A.2.7.1.2 Operations Environmental Monitoring Program. During the operations phase, the environmental monitoring program will be as defined in Table A-7.

A.2.7.1.3 Closure Environmental Monitoring Program. During the closure phase, the environmental monitoring program will continue exactly the same as during the operations phase, as shown in Table A-7. Following site closure, the potential for contaminant releases will be greatly reduced. It is anticipated that the environmental monitoring results will demonstrate the expected performance of the site following cessation of operations. During this phase, one additional test, the final external gamma ground survey, will be performed to document site exposure levels at the end of the last year of the closure period.

A.2.7.1.4 Post-closure Environmental Monitoring Program. At the end of the closure period, it is planned that the site will be turned over to a governmental agency for long-term custodial care throughout the post-closure period. It is also assumed that the site must be performing as planned prior to, and as a condition for, the turnover to a governmental agency to occur. During the post-closure period, it is expected that a groundwater sampling program would give the first indication of any difficulties with site performance. Therefore, during the postclosure period, the environmental monitoring program will be reduced to monitoring only the groundwater release pathways. Groundwater pathways are the most likely release pathways, and will be monitored on an annual basis, as shown in Table A-8. 
Table A-6. Baseline monitoring during pre-operational period.

\begin{tabular}{|c|c|c|c|c|c|}
\hline $\begin{array}{l}\text { Environmental } \\
\text { Medium }\end{array}$ & Type & Number & Frequency & $\begin{array}{l}\text { Radiological } \\
\text { analyses }\end{array}$ & $\begin{array}{l}\text { Chemical } \\
\text { analyses }\end{array}$ \\
\hline External gamma & TLD & 16 & Quarterly & Gamma/beta & - \\
\hline Soil & Surface & 20 & Quarterly & $\begin{array}{l}\text { Gross, } \\
\mathrm{H}-3\end{array}$ & - \\
\hline Soil & Surface & 20 & Quarterly & Specific & $\begin{array}{l}\text { TAL metals, } \\
\text { volatile, } \\
\text { semivolatiles }\end{array}$ \\
\hline Soil & Sediment & 3 & Quarterly & $\begin{array}{l}\text { Gross, } \\
\text { H-3 }\end{array}$ & \\
\hline Soil & Sediment & 3 & Quarterly & Specific & $\begin{array}{l}\text { TAL metals, } \\
\text { volatile, } \\
\text { semivolatiles }\end{array}$ \\
\hline Air & Particulate & 4 & Weekly & Gross & \\
\hline Air & Particulate & 1 & Monthly & Specific & \\
\hline Air & Water Vapor & 1 & Monthly & $\mathrm{H}-3$ & \\
\hline Air & lodine & 1 & Monthly & $\mathrm{I}-129,125$ & \\
\hline Air & Iodine & 1 & Weekly & $\mathrm{I}-131$ & \\
\hline Air & Gaseous & 1 & Monthly & $\begin{array}{l}\mathrm{H}-3, \\
\mathrm{C}-14 \\
\mathrm{Kr}-85\end{array}$ & \\
\hline Vegetation & Crop & 16 & Quarterly & Specific & TAL metals \\
\hline Vegetation & Non-Crop & 20 & Quarterly & $\begin{array}{l}\text { Gross, } \\
\mathrm{H}-3\end{array}$ & TAL metals \\
\hline Water & Surface & 3 & Quarterly & $\begin{array}{l}\text { Gross, } \\
\mathrm{H}-3\end{array}$ & \\
\hline Water & Surface & 3 & Quarterly & Specific & $\begin{array}{l}\text { TAL metals, } \\
\text { volatile, } \\
\text { anions }\end{array}$ \\
\hline Water & Ground & 20 & Quarterly & $\begin{array}{l}\text { Gross, } \\
\text { specific, } \\
\mathrm{H}-3\end{array}$ & $\begin{array}{l}\mathrm{pH}, \\
\text { conductivity, } \\
\text { TOC, } \\
\mathrm{TOX}, \\
\mathrm{Ca}^{+}, \mathrm{Na}^{+}, \mathrm{K}^{+}, \\
\mathrm{Mg}^{++}, \\
\text {anions, } \\
\text { oil and grease }\end{array}$ \\
\hline
\end{tabular}


Table A-6. Continued.

\begin{tabular}{|c|c|c|c|c|c|}
\hline $\begin{array}{l}\text { Environmental } \\
\text { Meditim }\end{array}$ & Type & Number & Frequency & $\begin{array}{l}\text { Radiological } \\
\text { analyses }\end{array}$ & $\begin{array}{l}\text { Chemical } \\
\text { analyses }\end{array}$ \\
\hline Water & Ground & 20 & Quarterly & Specific & $\begin{array}{l}\mathrm{CN}^{-} \text {, volatile, } \\
\text { semi } \\
\text { volatile }\end{array}$ \\
\hline Water & Potable & 3 & Quarterly & Specific & $\begin{array}{l}\mathrm{pH}, \\
\text { conductivity, } \\
\mathrm{TOC}, \mathrm{TOX}, \\
\mathrm{Ca}^{+}, \mathrm{Na}^{+}, \mathrm{K}^{+}, \\
\mathrm{Mg}^{++}, \text {anions, } \\
\text { oil and grease, } \\
\mathrm{CN}^{-} \text {, volatile, } \\
\text { semivolatiles }\end{array}$ \\
\hline Water & Precipitation & 1 & Monthly & Gross, H-3 & \\
\hline Biota & Small mammals & $\begin{array}{l}1 \text { each, } \\
3 \text { species }\end{array}$ & Quarterly & Gross & TAL metals \\
\hline Biota & Game birds & $\begin{array}{l}1 \text { each, } \\
3 \text { species }\end{array}$ & Quarteriy & Gross & TAL metals \\
\hline Biota & Fish & $\begin{array}{l}3 \text { species } \\
\text { upstream } \\
\text { and } 3 \\
\text { species } \\
\text { down- } \\
\text { stream }\end{array}$ & Quarterly & Gross & TAL metals \\
\hline Foodstuff & Milk & $\begin{array}{l}1 \text { upwind } \\
\text { and } 1 \\
\text { downwind }\end{array}$ & Quarterly & I-129 & \\
\hline
\end{tabular}

\section{A.2.7.2 Analysis Methods}

Gross alpha and gross beta analyses of environmental samples are cost-efficient screening techniques for detection of radionuclide contamination, but cannot determine the radionuclide present or distinguish between naturally occurring radionuclides and other contaminant radionuclides. Gamma spectroscopy can distinguish gamma-emitting radionuclides, but can experience interference from sample matrices and background, and is incapable of detecting nongamma-emitting radionuclides. Screening techniques such as these can often detect radionuclides 


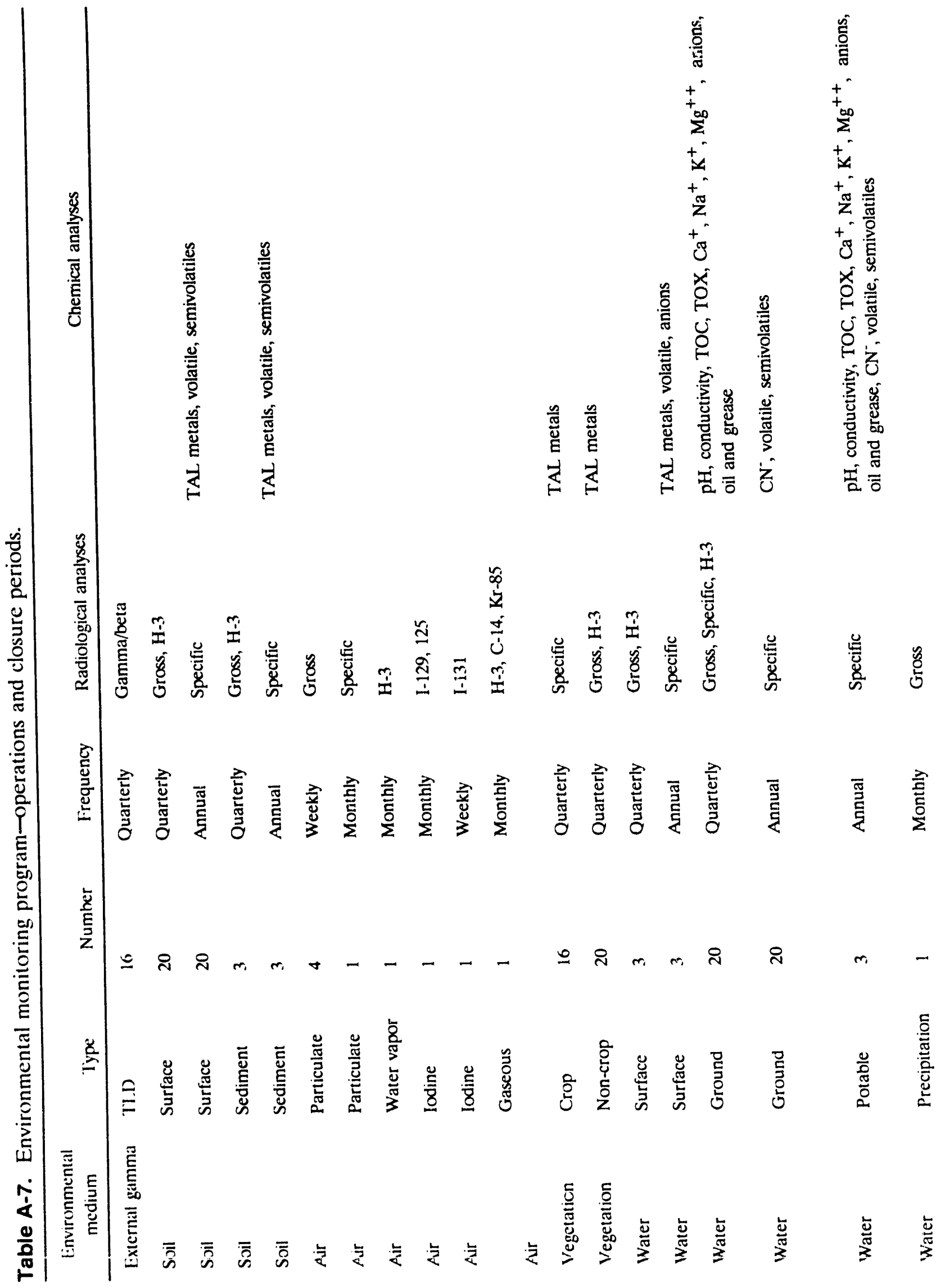




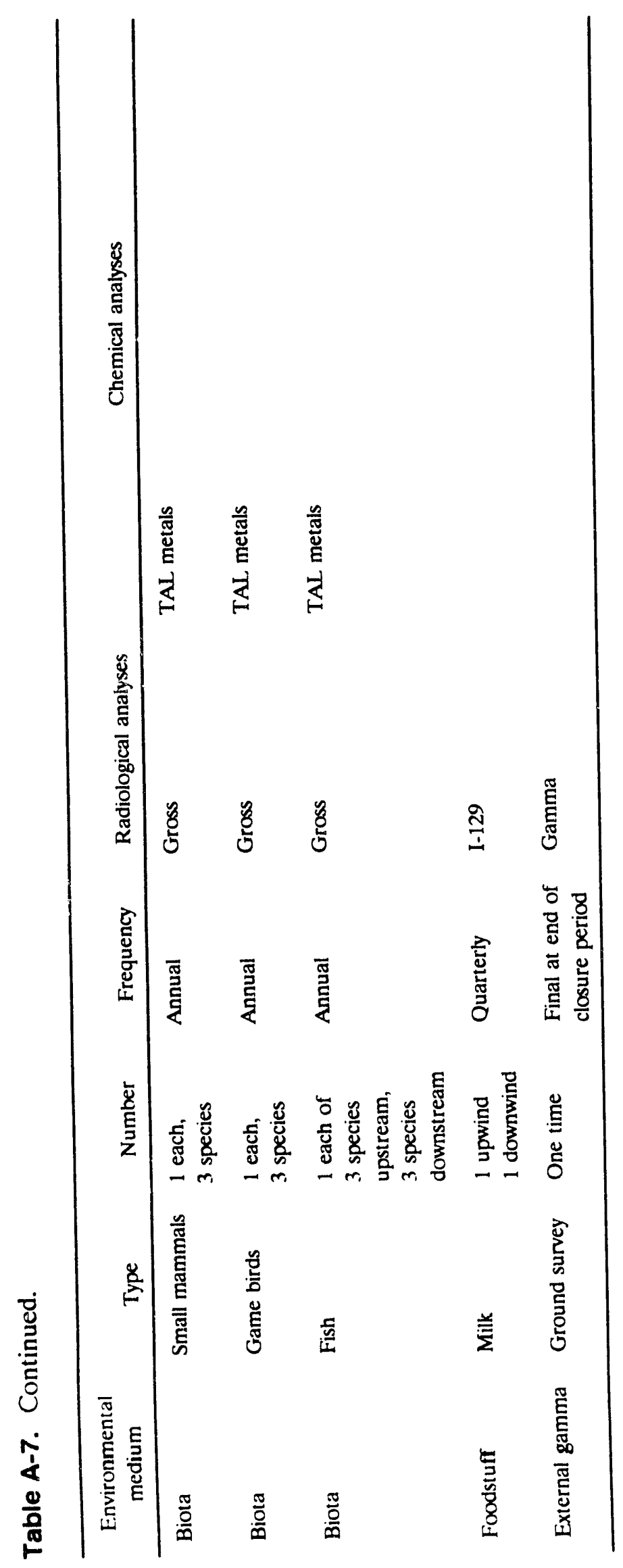

A-22 
Table A-8. Environmental monitoring program-post-closure period.

\begin{tabular}{|c|c|c|c|c|c|}
\hline $\begin{array}{l}\text { Environmental } \\
\text { medium }\end{array}$ & Type & Number & Frequency & $\begin{array}{l}\text { Radiological } \\
\text { Analyses }\end{array}$ & $\begin{array}{l}\text { Chemical } \\
\text { A.nalyses }\end{array}$ \\
\hline Water & Ground & 20 & Annual & $\begin{array}{l}\text { Gross, } \\
\text { specific, } \\
\text { H-3 }\end{array}$ & $\begin{array}{l}\mathrm{pH}, \\
\text { conductivity, } \\
\mathrm{TOC}, \mathrm{TOX}, \\
\mathrm{Ca}^{+}, \mathrm{Na}^{+}, \mathrm{K}^{+}, \\
\mathrm{Mg}^{++}, \\
\text {anions, } \\
\text { oil and grease }\end{array}$ \\
\hline Water & Ground & 20 & Annual & & $\begin{array}{l}\mathrm{CN}^{-} \\
\text {volatile, } \\
\text { semivolatiles }\end{array}$ \\
\hline
\end{tabular}

for which specific analysis was not performed. Specific radionuclide analysis can characterize which radionuclides are present in the sample, but at a much increased cost. Acombination of these analysis methods are used in the environmental monitoring program to provide adequate monitoring in a cost-effective manner.

Total organic carbon (TOC), total organic halogens (TOX), and oil and grease analyses are cost-efficient chemical screening techniques performed on environmental samples. Characterization analyses such as target analyte list (TAL) metals, target compound list (TCL) volatile, and semivolatiles are chemical analyses capable of determining the presence of the specific chemical constituents. Water quality analyses are used to determine the acceptability of drinking water.

Each type of analysis can be used in an environmental monitoring program to perform more frequent screening or less frequent characterization analysis. If screening analysis detects the presence of radionuclides or hazardous chemicals, it may be necessary to perform characterization analyses on the sample to better understand the contamination present.

Although the facility will be operated to prevent disposal of hazardous chemical and mixed waste, the potential exists for inadvertent acceptance of such materials, and the facility will be accepting some nonhazardous chemicals that are contaminated with radionuclides. Thus, the environmental monitoring program must be capable of monitoring for these materials.

A.2.7.2.1 External Dose Rate Ground Survey. Performance of an initial site gamma survey using natural background range field instrumentation will provide detection and documentation of any pre-existing external exposure anomalies at the site. This survey will provide detection of any areas that may have a previous radiological history and establish a baseline for comparison with a similar survey to be performed at closure. 
Repetition of the site gamma survey following closure of the facility, at the end of the closure period, will document increased exposure levels associated with the entombed waste and verify the absence of any other increases.

A.2.7.2.2 External Exposure (TLD) Monitoring. A system of 16 thermoluminescence dosimeter (TLD) stations will be deployed at equal distances along the site boundary to monitor for increased gamma or beta exposure resulting from site releases. Dosimeters will be exchanged on a quarterly basis to provide multiple readings for each site and to provide adequate data for annual data analysis and reporting.

A.2.7.2.3 Soil Surface Sampling. Surface soil sampling will be performed at 20 locations at the site to monitor for surface deposition of radionuclides and chemical contaminants. Sixteen soil sampling locations will surround the facility, with four additional samples taken at random or suspect locations, including locations within the site. Quarterly radionuclide screening analysis and tritium analysis will be performed, and annual (quarterly during the one-year pre-operational baseline monitoring period) analysis of samples for specific radionuclide and chemical characterization analysis will be performed.

A. 2.7.2.4 Drilling Core Analysis. Borcholes are drilled as part of site characterization or construction activities. Radionuclide and chemical analyses will be performed on borehole samples to detect any pre-existing underground contamination. Such contamination could affect the siting decision for the waste disposal facility. Radionuclide screening analysis will be performed, and can be supplemented with additional specific radionuclide analysis if necessary.

A.2.7.2.5 Sediment Sampling. Stream bed, runoff course, and retention basin sediment sampling will be used to detect surface water contamination. Sediments tend to concentrate radionuclides from the surface water and act as a good indicator of contamination. Three sites will be selected based on surface water flow through the site. Quarterly analyses for radionuclide screening and tritium will be performed, with annual (quarterly during the one-year preoperational baseline monitoring period) radionuclide specific and chemical characterization analysis.

A.2.7.2.6 Air Sampling. Continuous air sampling will be performed, with analysis, on a periodic basis. Four air particulate sampling stations will be located at the north, south, east, and west site boundaries, with weekly analysis for radionuclide screening and monthly composite sample analysis for specific radionuclides. A single onsite air sampling station will continually collect air samples for other analyses. Water vapor will be analyzed monthly for tritium, and air will be analyzed monthly for long-lived iodine radionuclides, and weekly for short-lived iodine- 131. Gas samples will be collected and analyzed monthly for carbon-14, tritium, and krypton-85.

A.2.7.2.7 Vegetation Sampling. Food and non-food vegetation samples will be collected 10 deket radionuclide deposition in hoth the human and animal food chain. Food crops will be sampled on a quarterly basis at the nearest growing location in each of the 16 sectors surrounding the site. Specific radionuclide analysis will be performed because of the human consumption of this sampling medium. Chemical analysis for metals will also be performed. Non-crop vegetation 
will be sampled near the same 20 locations used for surface soil sample points. Quarterly analysis for radionuclide screening, tritium, and chemical analysis for metals will be performed. Organic compounds will be detected in soil sampling, precluding the need for this analysis of vegetation samples.

A.2.7.2.8 Surface Water. Surface water sampling will be performed at three locations, based on water flow across the site. Quarterly samples will be analyzed for radionuclide screening and tritium; composite samples will be analyzed annually for specific radionuclides and chemical characterization.

A.2.7.2.9 Groundwater. Groundwater will be sampled from 20 locations on and off the site. The location of monitoring wells will be established based on the hydrology of the site. Some monitoring wells will be specifically drilled for this purpose, and some site characterization boreholes will be converted for this use. Samples will be analyzed for radionuclide screening, specific radionuclides, tritium, a suite of water quality indicators, and chemical screening analyses on the following schedules:

- Pre-operations baseline monitoring period-quarterly

- Operations and closure periods-quarterly

- Post-closure period-annually.

Samples will be analyzed for chemical characterization on a quarterly basis during the preoperational baseline monitoring period, and on an annual basis in all other periods.

A.2.7.2.10 Potable Water. Three existing potable water supply sources will be sampled on an annual basis to detect direct contamination of this human intake pathway. Annual analysis for specific radionuclides, water quality indicators, and chemical screening and characterization analyses will be performed.

A.2.7.2.11 Precipitation. Precipitation may collect airborne contaminants, returning them to the ground for plant, animal, or human uptake. Rainwater or snow melt collected at one site location will be analyzed monthly for radionuclide screening and tritium analysis.

A.2.7.2.12 Small Mammals. One specimen each of three representative snecies of small mammals that have access to the waste disposal site will be trapped on an annual basis (quarterly during the one-year pre-operational baseline monitoring period). This will allow determination if animal uptake is occurring, which if present, could result in surface deposition or offsite migration of contaminants. Animal tissue analysis will be performed for radionuclide screening and metals analysis.

A.2.7.2.13 Game Birds. These animals represent a potential direct human uptake pathway. One specimen each of three representative species will be collected on an annual basis 
(quarterly during the one-year pre-operational baseline monitoring period). Radionuclide screening and metals analysis will be performed.

A 2.7.2.14 Fish. Fish species that live in waters with the potential for contamination by releases from the site represent a potential human intake pathway. Annually (quarterly during the one-year pre-operational Baseline Monitoring period), one sample of each of three species will be taken from downstream locations and from upstream locations for comparison. Tissue analysis will be performed for radionuclide screening and metals analysis.

A.2.7.2.15 Milk. Milk represents the peak of the concentration chain for human consumption of iodine nuclide. One sample of locally produced milk will be obtained from both upwind and downwind (based on the predominant wind direction) locations on a quarterly basis. Analysis for long-lived iodine-129 will be performed.

\section{A.2.8 Quality Assurance}

A license application to design, construct, and operate a LLW disposal facility must provide for a quality assurance program. According to 10 CFR $61.12(\mathrm{j})$, this program must include a quality control program for the determination of natural disposal site characteristics and for quality control during the design, construction, operation, and closure of the facility; and the receipt, handling, and emplacement of the waste. Provisions for audits and managerial controls must also be included. Several documents ${ }^{4.5 .6}$ provide guidance on the application of quality assurance standards to LLW disposal activities. Specific guidance for LLW disposal facilities on meeting the quality control and quality assurance requirements of $10 \mathrm{CFR}$ 61.12(j) is provided by the NRC in NUREG 1293, Revision $1 .^{7}$

LLW disposal facilities are comprised of structures, systems, and components that prevent or mitigate the consequences of postulated releases of radioactivity that could affect the health and safety of the public. Such systems, structures, and components are classified for quality assurance purposes, in terms of two quality levels denoted by Quality Levels "Q" and "non-Q."

\section{A.2.8.1 Quality Level Q}

Plant and facility systems, structures, components, or services essential for safe operational control or whose failure could result in undue radiological risks to employees or to public health and safety require special measures during design, construction, and operation as determined by the regulators of the facility. All engineered safeguards and other items that directly prevent or mitigate the consequences of potential releases of radioactivity involving undue radiological risk to employees or public health and safety are designated Quality Level Q. Quality Level Q systems and components also include systems, structures, or components whose failure would cause predictable degradation of performance or reliability relative to facility operations.

This report assumes that the earth cover, concrete vault, and waste storage building conform (1) Quality I cevel Q and standards. 


\section{A.2.8.2 Quality Level Non-Q Items}

Systems and components whose failure would not directly result in an undue radiological risk to employees or public health and safety are designated Non-Q. Non-Q systems and components include those items for applicable codes, standards, or specifications do not require a quality assurance program to be implemented. All land improvements and buildings not used for waste storage are classified as Non-Q items. Quality levels for major systems are summarized in Table A-9.

Table A-9. Quality levels for major systems.

\begin{tabular}{lc}
\hline \multicolumn{1}{c}{ Major system } & Quality level \\
\hline Earth cover & $\mathrm{Q}$ \\
Concrete vault & $\mathrm{Q}$ \\
Waste storage building & $\mathrm{Q}$ \\
Other support buildings & Non-Q \\
Land improvements & Non-Q \\
\hline
\end{tabular}




\section{A.3 SITE OPERATIONS}

\section{A.3.1 Waste Receipt, Waste Disposal, and Facility Closure}

The operational period begins when construction of all buildings, utilities, land improvements, and support structures are completed and the facility has received all required licenses and permits, and met all regulatory requirements. The fir $t$ disposal cells are constructed at the beginning of the first opcrating season and construction of one cell for each of the two waste vaults is estimated to require one month. Waste is delivered on trucks to the disposal facility complete with all required documentation. The waste packages are removed from the truck and inspected to verify the integrity of the package and the adequacy of required documentation. The waste is then transported to the appropriate cell for either Class A or Class $\mathrm{B} / \mathrm{C}$, and is placed inside the cell using a crane. The cells of the vault are sized so that, on average, one cell will be filled cach year. Waste is received and placed for two months of each year, although the waste storage building has storage capacity for up to $30,000 \mathrm{ft}^{3}$ of waste in the event that the waste receipt rate exceeds the placement rate or if it is necessary to store waste that is received when placement operations are not active.

Waste is placed within the cell using a transportable crane and in such a way as to facilitate filling of the void spaces with sand or gravel as shown in Figure A-4. Class A cells will be filled completely with waste containers to within $2 \mathrm{ft}$ of the cell top while Class $\mathrm{B} / \mathrm{C}$ cells will be filled with waste to a depth of up to $4 \mathrm{ft}$ (i.e., not closer than $6.5 \mathrm{ft}$ to the cell top; see Figure A-2) and then the remaining space will be filled with gravel. At the conclusion of the receipt and placement activity, filled cells within the vault are closed with a concrete lid using the sand or gravel placed in the cell voids as shiclding for workers and as a form on the bottom. The concrete lid is designed to be self-supporting; however, casting the lid directly on top of the cell cuntents not only provides a form for the concrete, but also contributes to long-term stability of the vault by supporting the concrete lid. The integrity of the roof of the vaults will be maintained by preparing the joint between each section using sandblasting and surface pre-treatment. LLW can be packaged for transport to the disposal site in a variety of containers. For this study, a set of typical containers is used: 55 -gal $(208 \mathrm{~L})$ stecl drum, $4 \times 4 \times 8 \mathrm{ft}(1.2 \times 1.2 \times 2.4 \mathrm{~m})$ wooden or steel box, $6.5 \times 6.5 \mathrm{ft}$ diameter $(2 \times 2 \mathrm{~m}$ diameter $)$ stecl liner, 4 x $4 \mathrm{ft}$ diameter $(1.2 \times 1.2 \mathrm{~m}$ diameter steel liner in a shielded shipping cask, and a more heavily shielded horizontal shipping cask with nominal dimensions of $12 \times 1 \mathrm{ft}$ diameter $(3.7 \times 0.3 \mathrm{~m}$ diameter) for waste emitting higher levels of radioactivity.

The size of each cell was determined on the basis of calculations that considered the average annual volume of waste as well as the mix of containers likely to be encountered. The calculations are provided in Appendix C. The number of waste containers expected by type and class are summarized in Table A-10.

The lacility will receive and place waste during two-month campaigns in each operating year. The first cells will be constructed before initiating operations, but subsequent cells will be constructed only as required prior to each operating campaign. As a result of variations in waste 


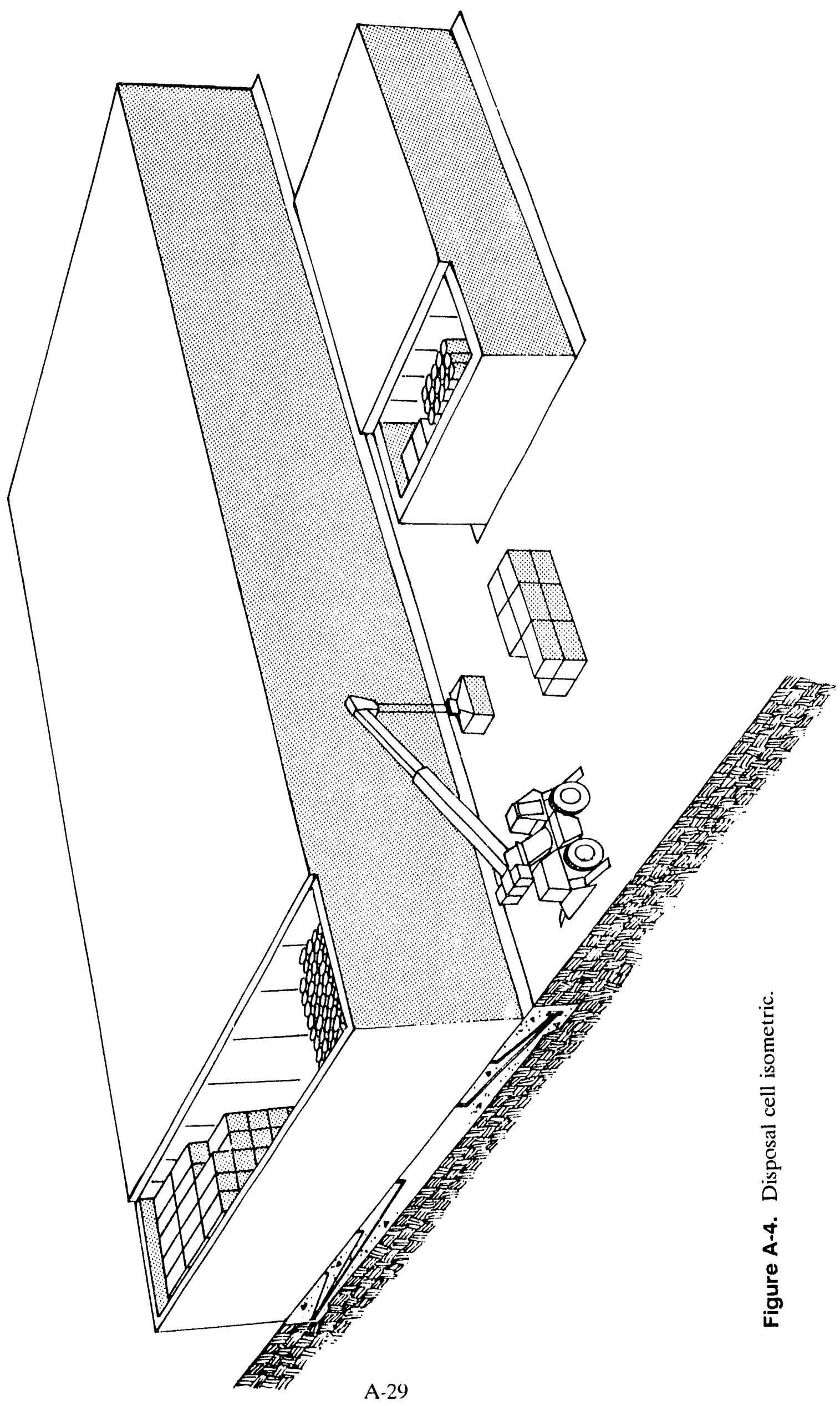


Table A-10. Number of waste containers by type and class.

\begin{tabular}{lccccc}
\hline & & \multicolumn{4}{c}{ Number of containers } \\
\cline { 3 - 6 } \multicolumn{1}{c}{$\begin{array}{c}\text { Shipping } \\
\text { container }\end{array}$} & $\begin{array}{c}\text { Container } \\
\text { volume }\left(\mathrm{ft}^{3}\right)\end{array}$ & $\begin{array}{c}\text { Containers } \\
\text { per year, } \\
\text { Class A }\end{array}$ & $\begin{array}{c}\text { Containers } \\
\text { per year, } \\
\text { Class B/C }\end{array}$ & $\begin{array}{c}\text { Total } \\
\text { containers } \\
(30 \text { years), } \\
\text { Class A }\end{array}$ & $\begin{array}{c}\text { Total } \\
\text { containers } \\
\text { (30 years), } \\
\text { Class B/C }\end{array}$ \\
\hline $\begin{array}{l}55 \text {-gal steel } \\
\text { drums in pallets }\end{array}$ & 7.5 & 1207 & 8 & 36,210 & 240 \\
of four each & & & & & \\
Boxes & 128.0 & 71 & 0 & 2,130 & 0 \\
Lincrs & 195 & 5 & 0 & 150 & 0 \\
Small casks & 50.3 & 193 & 15 & 5,790 & 450 \\
Horizontal casks & 9.4 & 25 & 11 & 750 & 330 \\
& & & & &
\end{tabular}

delivery, it may be necessary to leave a cell partially filled at the end of a campaign. A temporary, remuvable cover will be used in this instance to protect the waste from the elements until the next operating campaign.

At the end of the operational period, the disposal facility will be closed by placing an earthen cover over the above-grade vaults. The earthen cover depicted in Figure A-2 will first be raised to a slope of 1:2 (rise:run) and standpipes will be installed to allow monitoring of leachate that may accumulate in the sumps. Additional fill material, including clay to reduce the infiltration of precipitation and cobbles to deter intruders, will be added and the slope will be reduced to 1:5 (rise:run) to reduce erosion and promote long-term stability. The concrete walls and roof of the vault will also deter intruders.

The disposal site will be actively maintained during the periods of operations and site closure. The aim of maintenance is to limit, to the extent practicable, the effects of such degradation processes as erosion, concrete spalling, subsidence, biological intrusion, and inadvertent human intrusion. In the long-term, post-closure period, custodial care will be limited to minor custodial activities such as security, grounds care, painting, and fence maintenance and repair. All water will be actively collected from the sumps throughout the post-closure period.

\section{A.3.2 Radiological Safety}

The radiological protection program for the disposal facility must not only provide protection to both onsite and offsite individuals in compliance with 10 CFR 20, but also must maintain exposure as low as is reasonably achievable (10 CFR 20.1(c)). To meet these requirements, the 
facility will require a radiological protection staff to direct operations, provide radiological measurement, and perform the recordkeeping necessary for the program. A radiation safety officer is required as part of the permanent year-around staff; a senior health physics technician to perform environmental sampling is also required. Beginning one month before the receipt of waste (for training and re-certification), and during the entire campaign, two additional health physics technicians are required to provide radiological protection. Their services would not be required until resumption of the next annual campaign.

The NRC has recently promulgated a revision of 10 CFR $20,{ }^{8}$ which currently requires implementation by January 1,1993 , and a proposed rule ${ }^{9}$ has extended the implementation date to January 1, 1994. This revision incorporates the recommendations of the International Commission on Radiological Protection (ICRP) issued in 1977, and implements the recommendations contained in the Guidance to Federal Agencies for Occupational Exposure, signed by the President in 1987.

Impact of this change on the scope and extent of the radiological protection program is sigrificant for an existing program because of requirements for procedure revision and new procedure development, training updates, recordkceping modifications, and other miscellaneous changes. However, incorporation of these requirements into a new radiological protection program, such as that anticipated for this facility, would not incur update or modification costs.

\section{A.3.3 Industrial Safety}

The, potential exists for industrial accidents during waste disposal operations at any LLW disposal facility. As with any industrial operation, proper management and industrial safety practices during disposal operations can minimize the occurrence of worker accidents. 


\section{Appendix B}

\section{Dose Assessment}


$+1^{2}=12$

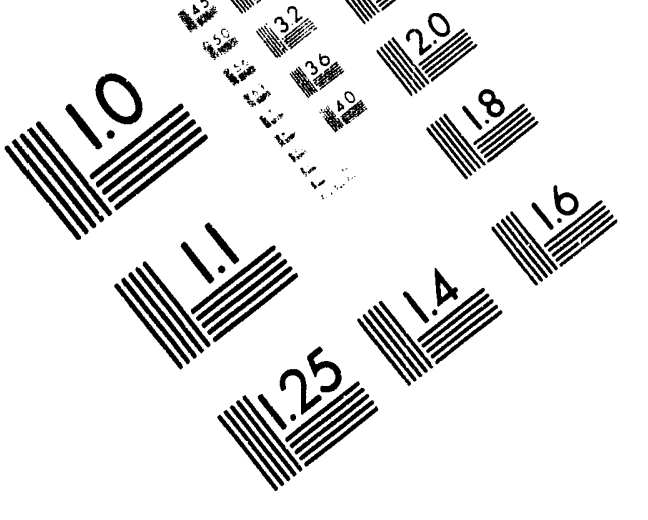

Association for Information and Image Management

1100 Wayne Avenue. Suite 1100
Silver Spring. Maryland 20910

301/587-8202

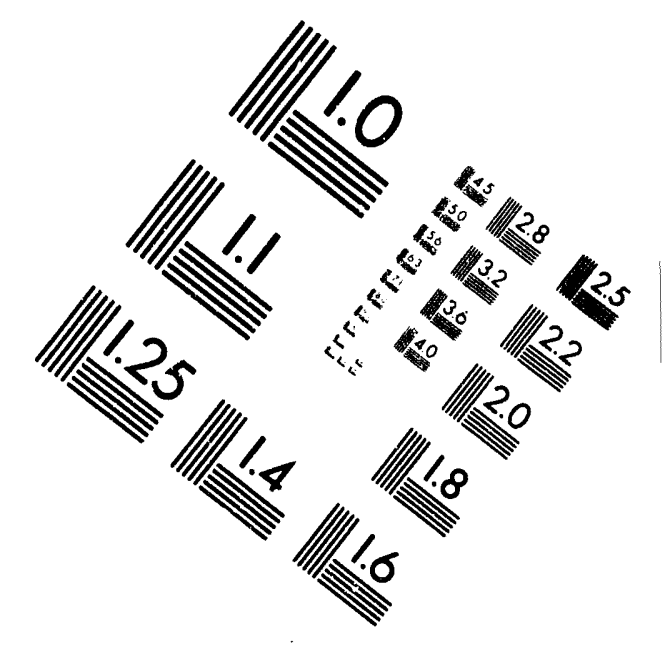

Centimeter

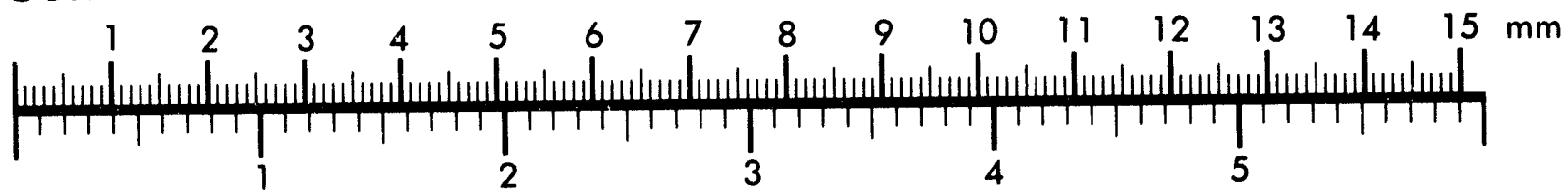

Inches
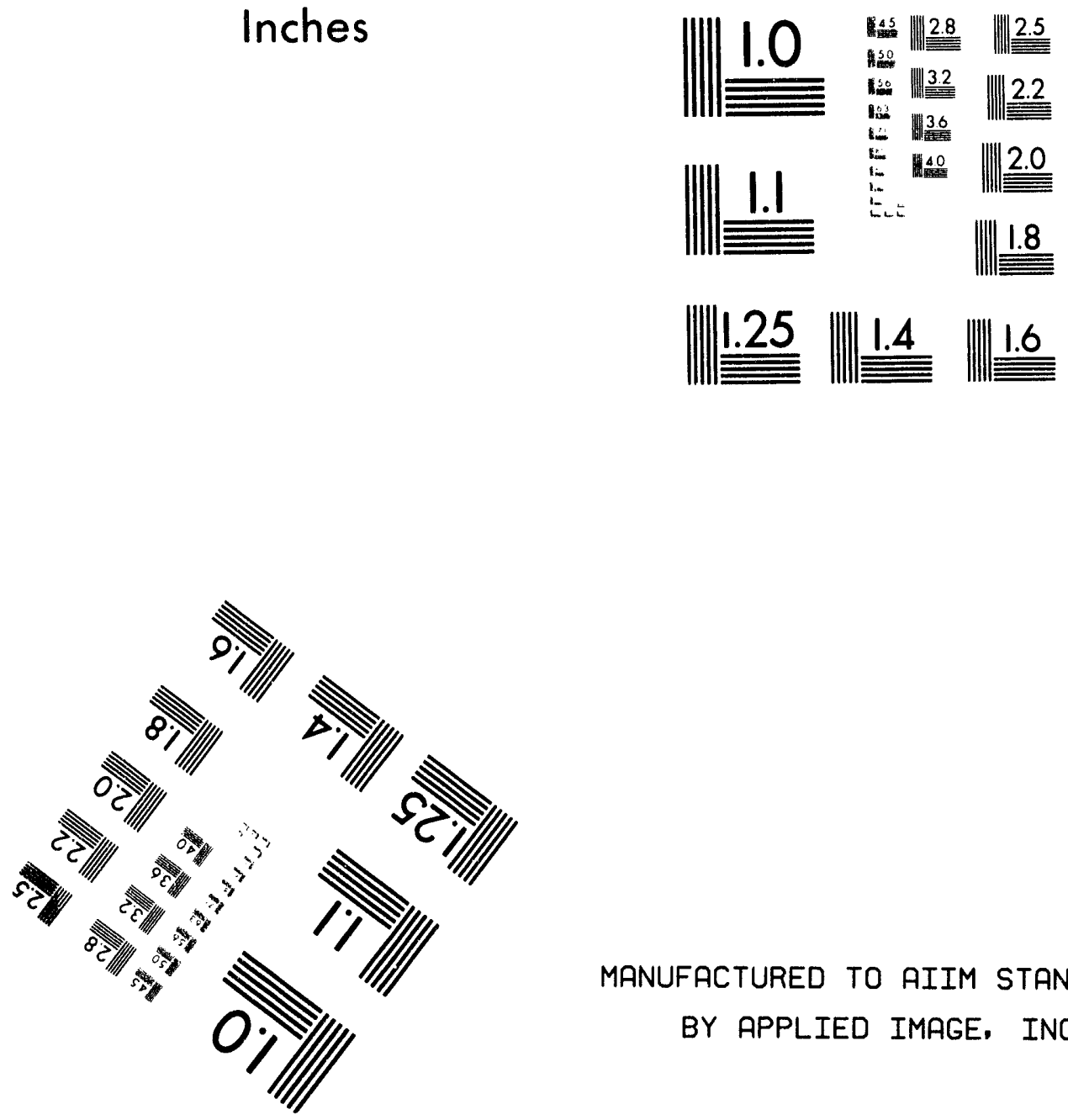

MANUFACTURED TO AIIM STANDARDS

BY APPLIED IMAGE, INC.

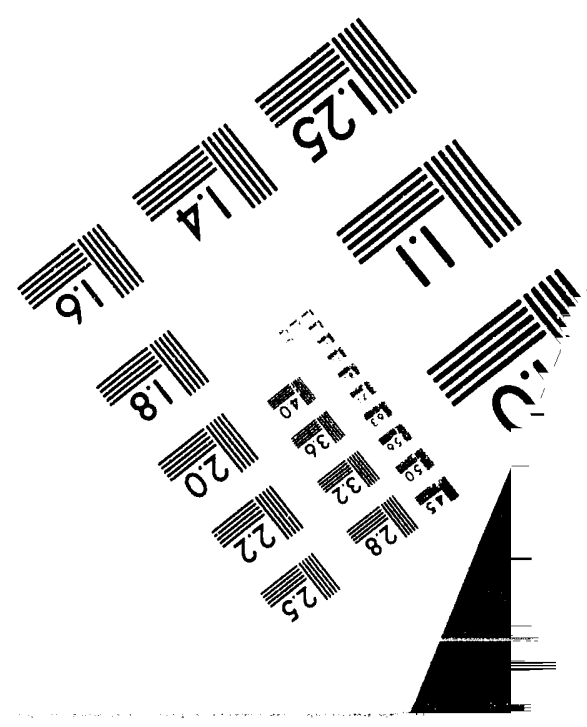



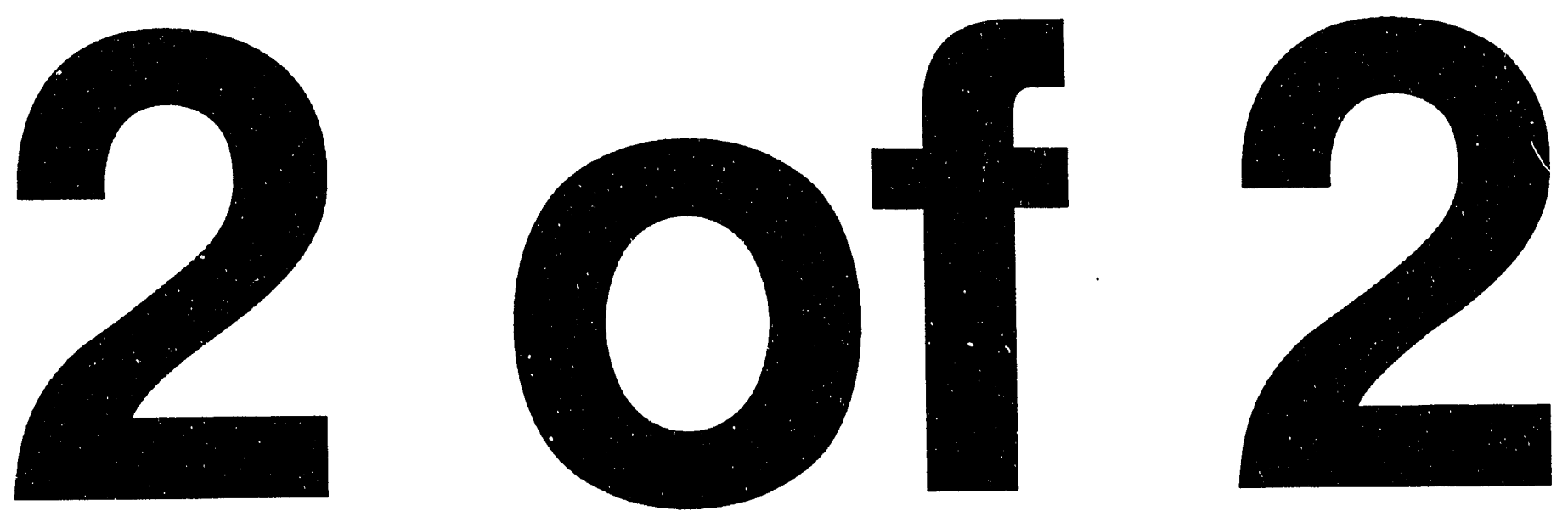


\section{Appendix B}

\section{Dose Assessment}

Site specific modeling of radiological impacts to the present and future population surrounding the proposed LLW disposal facility is necessary to ensure that the facility meets the performance requirements of 10 CFR 61.41:

"Concentrations of radioactive material which may be released to the general environment in ground water, surface water, air, soil, plants, or animals must not result in an annual dose exceeding an equivalent of 25 millirems to the whole body. 75 millirems to the thyroid, and 25 millirems to any other organ of any member of the public. Reasonable effort should be made to maintain releases of radioactivity in effluents to the general environment as low as is reasonably achievable."

In addition to performance requirements of 10 CFR 61, there are concentration limits for both air and water emissions from NRC licensed facilities (10 CFR 20) that must be met. It will be necessary to perform modeling to ensure that these concentrations are not exceeded during the operating life of the facility. The modeling necessary to determine compliance with 10 CFR 61 will, or can easily be, modified to provide the necessary concentration information.

Implementation of ICRP 26 concepts (effective dose equivalent) onto 10 CFR 20 may necessitate modification to the modeling techniques used to provide doses calculated with these updated techniques. Interpretation of the regulation with respect to these new dose concepts will be necessary to determine regulatory compliance.

New air emission regulations have been promulgated since the development of the conceptual design report, which may effect the design of the proposed LLW disposal facility. 40 CFR 61 Subpart I contains regulations for National Emission Standards for radionuclide emissions from facilities licensed by the NRC and Federal facilities not covered by Subpart H. Section 61.102 regulates airborne pathway exposure (in the ICRP 26 effective dose equivalent methodology):

"(a) Emissions of radionuclides, including iodine, to the ambient air from a facility regulated under this subpart shall not exceed those amounts that would cause any member of the public to receive in any year an effective dose equivalent of $10 \mathrm{mrem} / \mathrm{yr}$.

(b) Emissions of iodine to the ambient air from a facility regulated under this subpart shall not exceed those amounts that would cause any member of the public to receive in any year an effective dose equivalent of $3 \mathrm{mrem} / \mathrm{yr} . "$ 
Modeling will have to be performed to ensure compliance with these regulations. Use of the EPA COMPLY computer code is required to demonstrate compliance with these regulations.

The modeling required to meet the regulations noted above will have to be performed on a site specific basis for licensing the proposed LLW disposal facility. As noted in the conceptual design report, modeling performed there was to determine the relative performance of each of the proposed designs, and does not provide the data necessary for licensing any of the proposed designs, the proposed LLW facility design, or any site specific design. It is anticipated that as the modeling required for a site specific facility license is performed, the impact of these new regulations will be minimal.

Comparison of the gamma shielding provided by the two different vault/earth cover designs was performed to determine if external exposure would be significantly greater for the thinner earthen cover. Microshicld PC was used to compare a 1.5 -ft concrete/16.5 ft soil cover (Conceptual Design Report, earth-mouncled concrete bunker design), a $2.5 \mathrm{ft}$ concrete/6.5 ft soil cover (present earth-covered concrete vault design), and the no shielding case. Comparison was performed for both cobalt-60 and cesium-137 gamma rays to explore different gamma energies likely to account for external exposure from the low-level radioactive waste. Results indicate that an exposure reduction factor of $10^{-30}$ from the $16-\mathrm{ft}$ soil cover is reduced to $10^{-22}$ for the 6.5 - $\mathrm{ft}$ soil cover for cesium-137 gamma rays, and for cobalt-60 gamma exposure, $10^{-22}$ for the 16-ft soil cover reduces to $10^{-16}$ for the 6.5 -ft soil cover. These are all very substantial shielding factors, and both soil covers provide adequate shielding for the inadvertent intruder. Dose rate modeling for site specific licensing will provide dose rate estimates for the final facility design. 


\section{Appendix C}

\section{Cell Sizing Calculations}




$$
\text { C.- } 2
$$




\section{Appendix C}

\section{Cell Sizing Calculations}

The cell sizing calculations were developed to determine the size of the cells to be constructed each year for the receipt of low-level radioactive waste. These calculations were used to determine the material quantities for the construction cost estimate performed with the COSTPRO software. The size and type of containers to be placed in the cell are described in the assumptions on page C-5. 
C-4 
Objective: $\quad$ Size vaults for disposal of low-level waste. Develop separate vaults for Class $\mathrm{A}$ and Class $\mathrm{B} / \mathrm{C}$ wastes.

Basis: $\quad$ Historical data indicating the number of waste containers by waste class and waste type are listed in Table 3-10. Each cell should be sized to accommodate one year's volume at the projected rate. Class $\mathrm{B} / \mathrm{C}$ waste cells will be sized to allow $6.5 \mathrm{ft}$ of sandy gravel fill on top of waste. Class A cells will be filled completely with a small allowance for a sand bed to fill voids and to provide a level surface.

Assumptions:

1. Annual waste volume $=30,000$ c.f.

2. $97 \%$ of waste is Class $\mathrm{A}, 3 \%$ is Class $\mathrm{B} / \mathrm{C}$ (by volume)

3. Waste container dimensions are as follows

Drums (55 gal) : 22" ID, 34" high, $7.48 \mathrm{~cd} . / \mathrm{drum}$

Boxes : 4' $\mathrm{H} \times 4^{\prime} \mathrm{W} \times 8^{\prime} \mathrm{L}$

Steel Cylinder : $6.5^{\prime} \mathrm{D} \times 6.5^{\prime} \mathrm{H}$

Steel Cask : $6.5^{\prime} \mathrm{D} \times 6.5^{\prime} \mathrm{H}$

Shielded Cask : 1' $\mathrm{D} \times 12^{\prime} \mathrm{L}$

References : Conceptual Design Report

\section{Calculations}

1. Determine volume required for each waste package

A. Drums

1'-10" D

$2 "-10 " \mathrm{H}$

$\mathrm{V}=7.48$ c.f.

Volume of Waste in Drums $=29.92$ c.f.

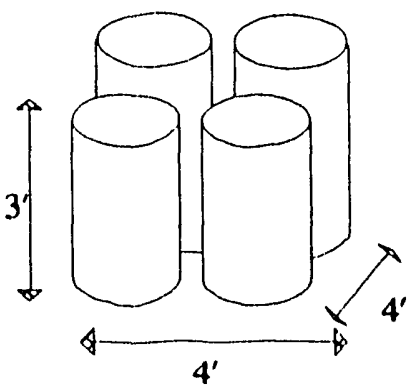

Volume Occupied by Cube $=48$ c.f.

Efficiency $=\frac{29.92}{48.00}=62 \%$ 
B. Box

$\mathrm{V}=128$ c.f.

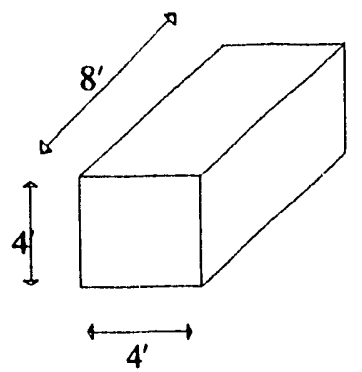

Volume of Box $=$ Volume of Cube $->$ Efficiency $=100 \%$

C. Liner

$\mathrm{V}=(3.25)^{2} \mathrm{pi} \times 6.5=216$ c.f.

Volume of Cube $=275$ c.f.

Efficiency $=\frac{216}{275}=79 \%$

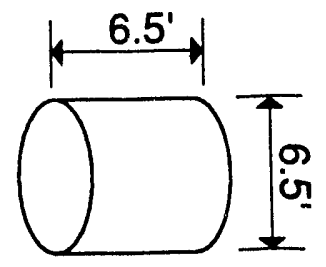

D. Cask

$\mathrm{V}=(2)^{2} \mathrm{pi} \times 4=50.3$ c.f.

Volume of Cube $=64$ c.f.

Efficiency $=\frac{50.3}{64}=79 \%$

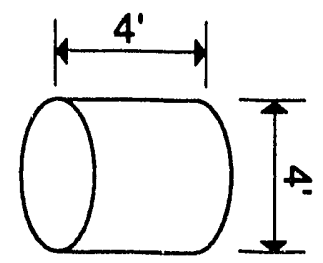

E. Shielded Cask

$\mathrm{V}=(0.5)^{2}$ pi $\times 12=9.4$ c.f.

Volume of Cube $=1 \times 1 \times 12=12$ c.f.

Efficiency $=\frac{9.4}{12}=78 \%$

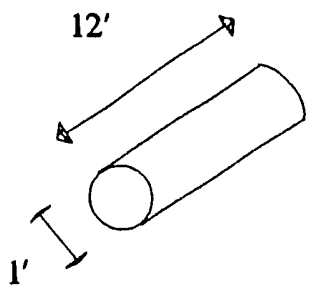

2. Determine volume required for Class $\mathrm{A}$ waste

A. Drums

1,207 Drums

30 pallets@ 4 drums each

$=120 \mathrm{drums} /$ segment

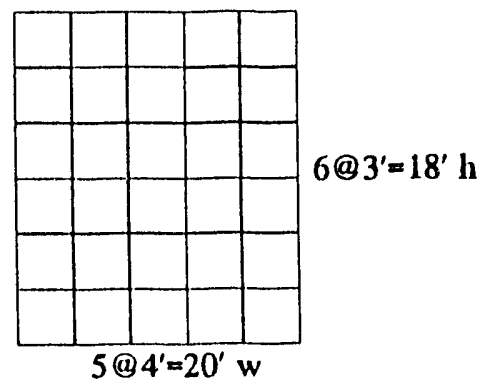

$\frac{1207}{120 \text { drums/segments }}=10.05$ segments (each segment is $4 \mathrm{ft}$ deep) 
Length $=11$ (round up) $\times 4=44^{\prime}$

B. Boxes

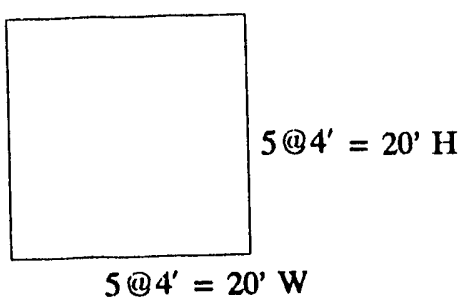

$\frac{71 \text { boxes }}{25 \text { boxes/segment }}=2.84$ segments (each segment is $8 \mathrm{ft}$ deep)

Length $=3$ (round up) $\times 8=\underline{24}$

C. Liners

5 liners;

one row of liners

designed to fit under and at the end of the shielded casks.

D. Casks

193 Casks

25 Casks per segment

$\frac{193}{25}=7.7$ (each segment is $4 \mathrm{ft}$ deep)

Length $=8$ (round up) $\times 4=\underline{32 \mathrm{ft}}$

E. Shielded Casks

25 Casks

$$
\begin{aligned}
& 1 \times 6.5^{\prime}=6.5^{\prime} \mathrm{H} \\
& 3 \times 6.5^{\prime}=19.5^{\prime} \mathrm{H} \\
& 3 \times 6.5^{\prime}=19.5^{\prime} \mathrm{W} \\
& 146.5^{\prime}=6.5^{\prime} \mathrm{L}
\end{aligned}
$$
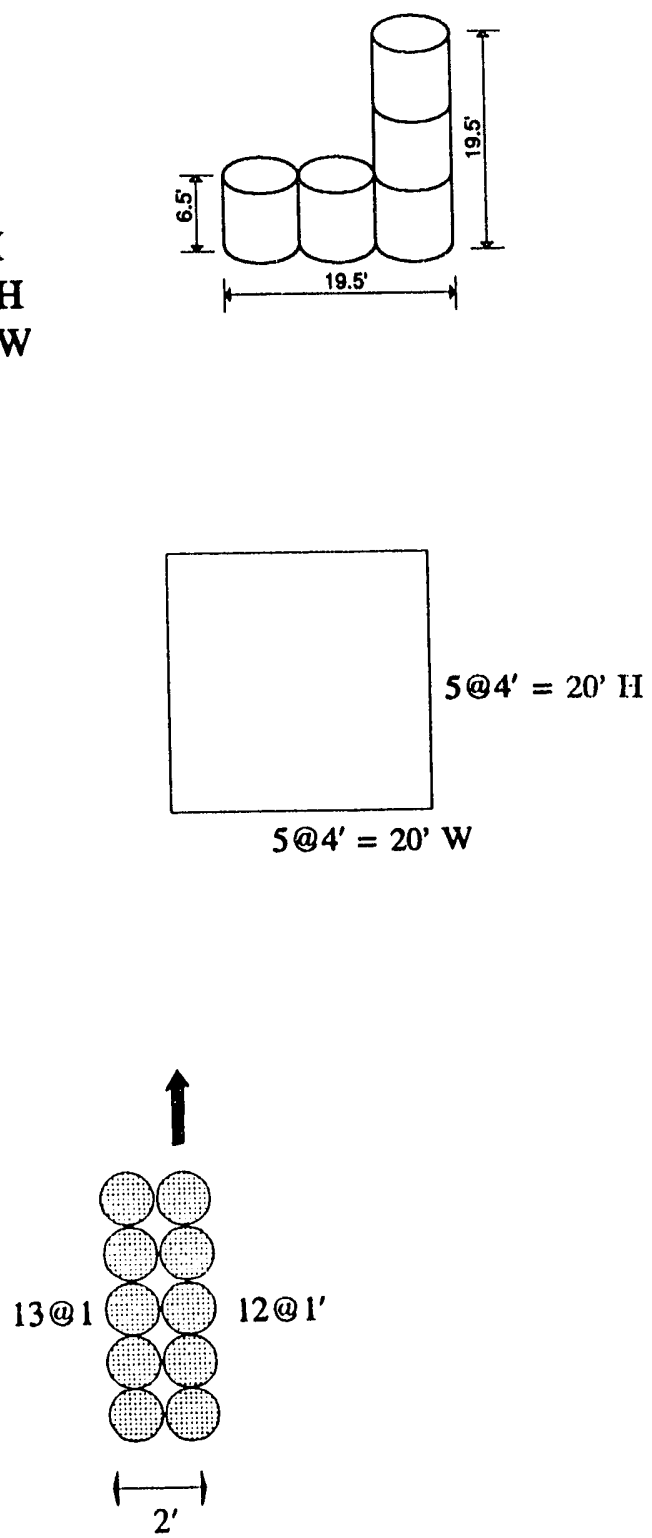
Incremental Length $=\underline{2}$

Summary

Drums

$20^{\prime} \mathrm{W}$

$18^{\prime} \mathrm{H}$

44' L

Boxes

20 ' W

20 ' H

24' L

Casks

20' W

$20^{\prime} \mathrm{H}$

32' L

Shielded Casks

$12^{\prime} \mathrm{W}$

$12 / 13^{\prime} \mathrm{H}-$ (on top of cylinders)

Cylinders

$6.5^{\prime} \mathrm{W}$

$6.5^{\prime} \mathrm{H}$

$\underline{6.5} \mathrm{~L}$

106.5

Total Length $=44^{\prime}($ drums $)+24^{\prime}$ (boxes $)+32^{\prime}($ Cask $)+6.5^{\prime}$ (Liners)

+1.5 clearance $=\underline{108 \mathrm{ft}}$

Width $=20^{\prime}+2^{\prime}$ clearance $=\underline{22^{\prime}}$

Height $=20^{\prime}+6^{\prime \prime}$ clearance $=\underline{20^{\prime}-6^{\prime \prime}}$

3. Determine volume requried for Class $B / C$ waste

A. 8 Drums

B. No Boxes

C. No Steel Cylinders

D. 15 Casks

E. 11 Shielded Casks
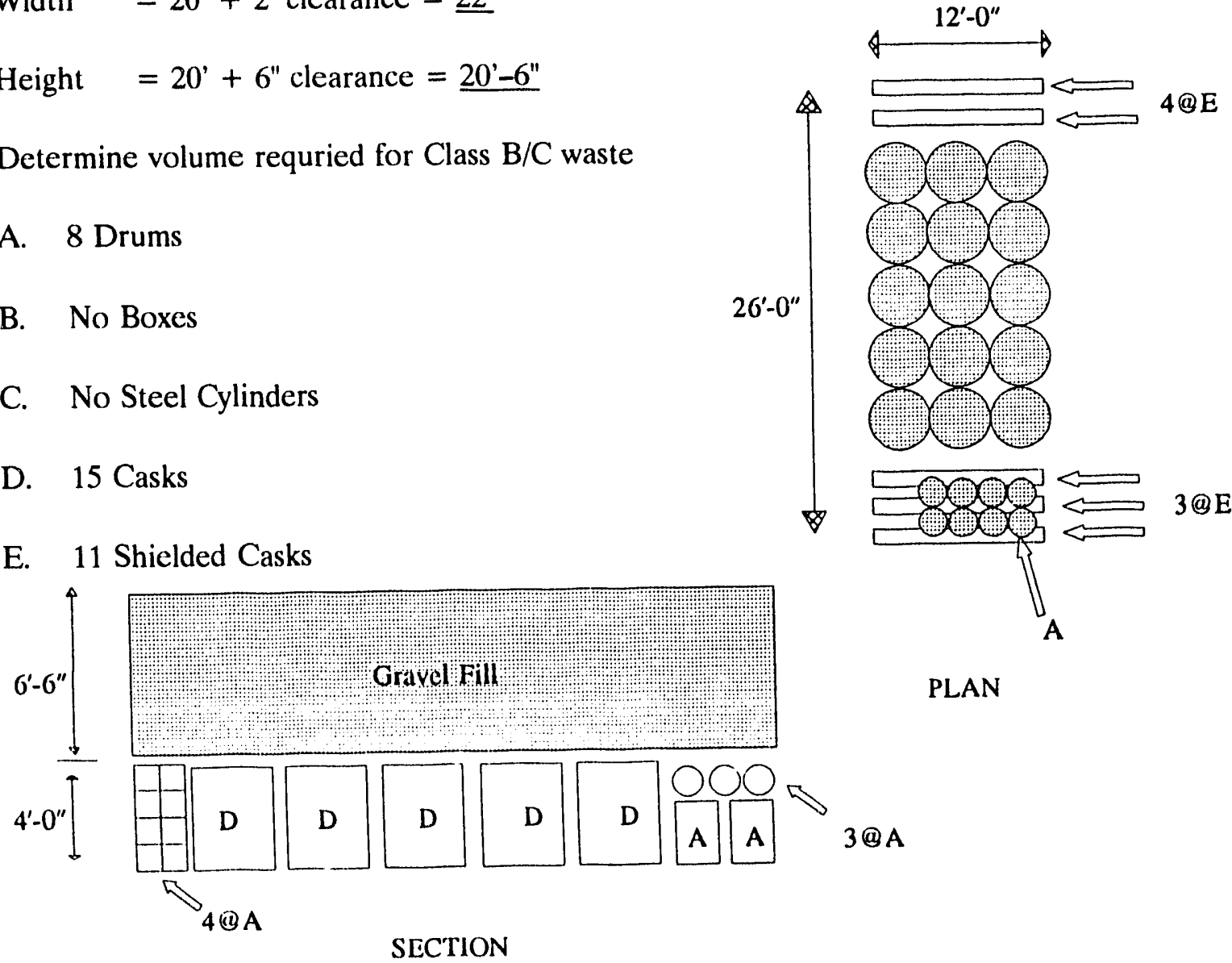

PLAN

Dimensions of $\mathrm{B} / \mathrm{C}$ Cell $=14^{\prime} \mathrm{W} \times 10^{\prime}-6^{\prime \prime} \mathrm{H} \times 28^{\prime} \mathrm{L}$ 
Appendix D

Contingency Analysis 
D-2 


\section{Appendix D}

\section{Contingency Analysis}

The contingency analysis provided in this appendix was developed using a risk weighted methodology that considers the importance and risk of a series of parameters that have been shown to influence cost risk. The factors are evaluated and scored on the basis of importance (influence on cost uncertainty) and risk (the likelihood of an unfavorable outcome). The result is a score ration that is applied to the recommended maximum contingency. The recommended maximum contingency is based on the degree of technical definition. The design of the facility considered for this study is considered to be at the planning/feasibility stage of development. The second part of the analysis considers special requirements and allows the user some flexibility to address project specific conditions. The result is a project-specific, risk-based cost contingency. 


\begin{tabular}{|c|c|c|c|}
\hline $\begin{array}{lr} & \text { CONTINGENC } \\
\text { PROJECT TITLE: } & \text { SMALL-VOL } \\
\text { Item Title: } & \text { Pre Operation }\end{array}$ & $\begin{array}{l}\text { LYSIS FOR PROJ } \\
\text { OW-LEVEL RADI }\end{array}$ & $\begin{array}{l}\text { ECT ESTIMATES } \\
\text { OACTIVE WASTE }\end{array}$ & FACILITY \\
\hline & \begin{tabular}{|l|} 
Relative \\
Weight \\
0 to 10 \\
$0=$ N/A \\
$10=$ Important
\end{tabular} & $\begin{array}{l}\text { Probability } \\
\text { Score } \\
1 \text { to } 10 \\
0=\text { Low Risk } \\
10=\text { High Risk }\end{array}$ & $\begin{array}{l}\text { Weighted } \\
\text { Score }\end{array}$ \\
\hline $\begin{array}{l}\text { Engineering Design \& Inspect. } \\
\text { Design Completeness } \\
\text { Site Selection/Conditions } \\
\text { Design Complexity } \\
\text { Specification Complexity } \\
\text { Design Schedule } \\
\text { Life Safety/Security }\end{array}$ & $\begin{array}{l}9 \\
8 \\
8 \\
8 \\
6 \\
6\end{array}$ & $\begin{array}{r}10 \\
8 \\
7 \\
8 \\
8 \\
8\end{array}$ & $\begin{array}{l}90 \\
64 \\
56 \\
64 \\
48 \\
48\end{array}$ \\
\hline $\begin{array}{l}\text { Construction } \\
\text { Types of Construction } \\
\text { Construction Complexity } \\
\text { Design Completeness } \\
\text { Market Conditions } \\
\text { Method of Accomplishment }\end{array}$ & $\begin{array}{l}8 \\
5 \\
8 \\
5 \\
5\end{array}$ & $\begin{array}{r}7 \\
7 \\
10 \\
5 \\
5\end{array}$ & $\begin{array}{l}56 \\
35 \\
80 \\
25 \\
25\end{array}$ \\
\hline $\begin{array}{l}\text { Special Facilities \& Equipment } \\
\text { Requestor's Specifications } \\
\text { Maturity of Technology } \\
\text { Design Completeness } \\
\text { Method of Accomplishment }\end{array}$ & $\begin{array}{l}7 \\
7 \\
8 \\
5\end{array}$ & $\begin{array}{r}6 \\
4 \\
10 \\
5\end{array}$ & $\begin{array}{l}42 \\
28 \\
80 \\
25\end{array}$ \\
\hline $\begin{array}{l}\text { Standard Equipment } \\
\text { Specification Completeness } \\
\text { Quantity Accuracy } \\
\text { Price Accuracy } \\
\text { Method of Accomplishment }\end{array}$ & $\begin{array}{l}8 \\
8 \\
8 \\
5\end{array}$ & $\begin{array}{l}6 \\
8 \\
5 \\
5\end{array}$ & $\begin{array}{l}48 \\
64 \\
40 \\
25\end{array}$ \\
\hline $\begin{array}{l}\text { Licensing \& Permitting } \\
\text { Regulatory Complexity } \\
\text { Schedule Impacts } \\
\text { Quality Assurance/Control }\end{array}$ & $\begin{array}{l}9 \\
7 \\
7\end{array}$ & $\begin{array}{r}10 \\
9 \\
9\end{array}$ & $\begin{array}{l}90 \\
63 \\
63\end{array}$ \\
\hline TOTALS & 155 & 160 & 1159 \\
\hline $\begin{array}{l}\text { Total Possible Score }= \\
\text { Total Relative Weights X } 10\end{array}$ & 1550 & & \\
\hline Score Ratio $=$ Total Weighted & Total Possible Sc & core $=$ & 0.748 \\
\hline
\end{tabular}




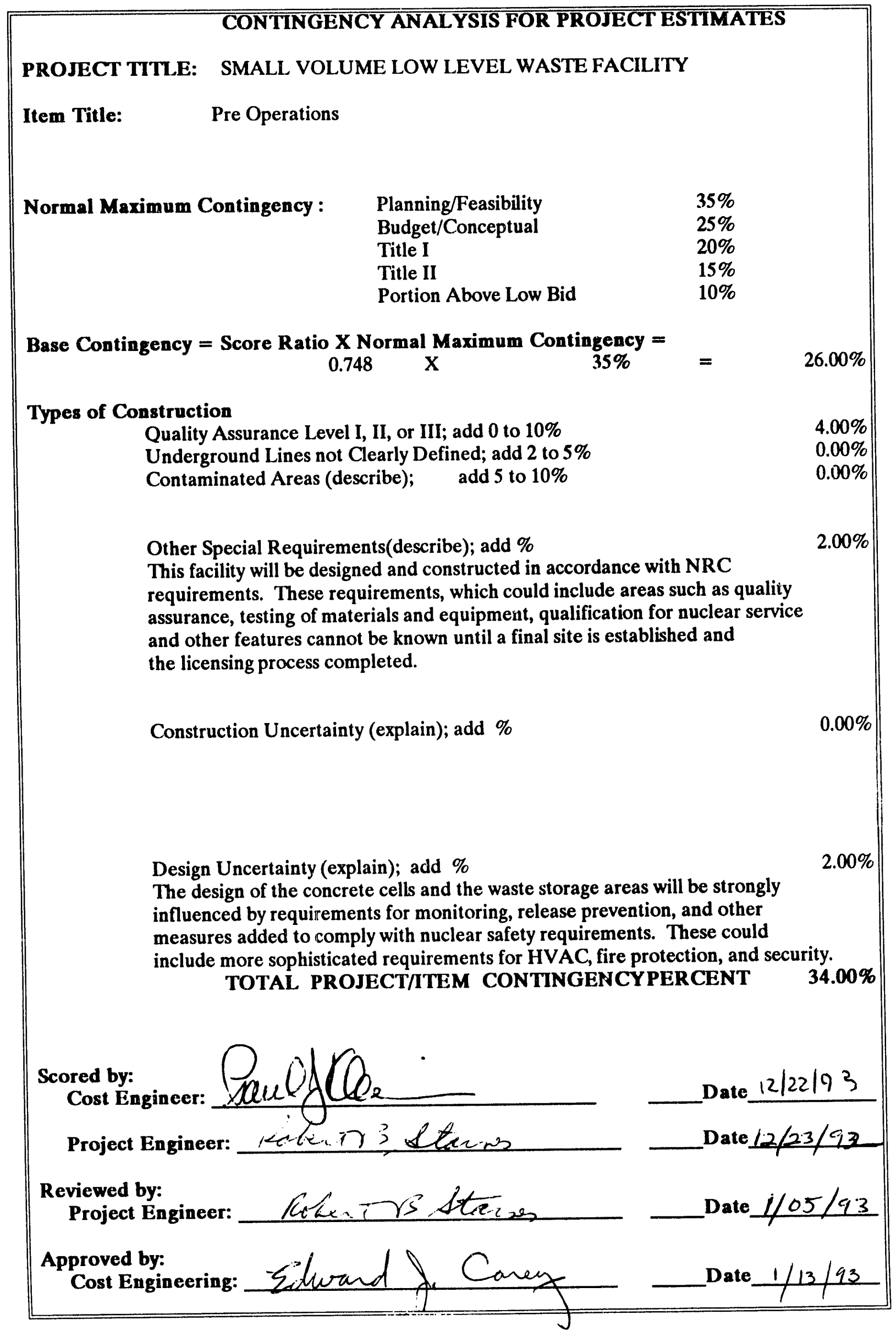

D-6 


\begin{tabular}{|c|c|c|c|}
\hline $\begin{array}{l}\text { CONTINGENC } \\
\text { PROJECT TITLE: SMALL VO } \\
\text { Item Title: } \quad \text { Operations }\end{array}$ & $\begin{array}{l}\text { YSIS FOR PROJ } \\
\text { OW LEVEL WAST }\end{array}$ & $\begin{array}{l}\text { ECT ESTIMAT } \\
\text { [E FACILITY }\end{array}$ & \\
\hline & $\begin{array}{l}\text { Relative } \\
\text { Weight } \\
0 \text { to } 10 \\
0=N / A \\
10=\text { Important }\end{array}$ & $\begin{array}{l}\text { Probability } \\
\text { Score } \\
1 \text { to } 10 \\
0=\text { Low Risk } \\
10=\text { High Risk }\end{array}$ & $\begin{array}{l}\text { Weighted } \\
\text { Score }\end{array}$ \\
\hline $\begin{array}{l}\text { Engineering Design \& Inspect. } \\
\text { Design Completeness } \\
\text { Site Selection/Conditions } \\
\text { Design Complexity } \\
\text { Specification Complexity } \\
\text { Design Schedule } \\
\text { Life Safety/Security }\end{array}$ & $\begin{array}{l}0 \\
0 \\
0 \\
0 \\
0 \\
0\end{array}$ & $\begin{array}{l}0 \\
0 \\
0 \\
0 \\
0 \\
0\end{array}$ & $\begin{array}{l}0 \\
0 \\
0 \\
0 \\
0 \\
0\end{array}$ \\
\hline $\begin{array}{l}\text { Construction } \\
\text { Types of Construction } \\
\text { Construction Complexity } \\
\text { Design Completeness } \\
\text { Market Conditions } \\
\text { Method of Accomplishment }\end{array}$ & $\begin{array}{l}0 \\
0 \\
0 \\
0 \\
0\end{array}$ & $\begin{array}{l}0 \\
0 \\
0 \\
0 \\
0\end{array}$ & $\begin{array}{l}0 \\
0 \\
0 \\
0 \\
0\end{array}$ \\
\hline $\begin{array}{l}\text { Special Facilities Equipment } \\
\text { Requestor's Specifications } \\
\text { Maturity of Technology } \\
\text { Design Completeness } \\
\text { Method of Accomplishment }\end{array}$ & $\begin{array}{l}0 \\
0 \\
0 \\
0\end{array}$ & $\begin{array}{l}0 \\
0 \\
0 \\
0\end{array}$ & $\begin{array}{l}0 \\
0 \\
0 \\
0\end{array}$ \\
\hline $\begin{array}{l}\text { Standard Equipment } \\
\text { Specification Completeness } \\
\text { Quantity Accuracy } \\
\text { Price Accuracy } \\
\text { Method of Accomplishment }\end{array}$ & $\begin{array}{l}0 \\
0 \\
0 \\
0\end{array}$ & $\begin{array}{l}0 \\
0 \\
0 \\
0\end{array}$ & $\begin{array}{l}0 \\
0 \\
0 \\
0\end{array}$ \\
\hline $\begin{array}{l}\text { Operations } \\
\text { Complexity } \\
\text { Schedule } \\
\text { Quality Assurance/Control }\end{array}$ & $\begin{array}{l}6 \\
6 \\
6\end{array}$ & $\begin{array}{l}9 \\
8 \\
8\end{array}$ & $\begin{array}{l}54 \\
48 \\
48\end{array}$ \\
\hline TOTALS & 18 & 25 & 150 \\
\hline $\begin{array}{l}\text { Total Possible Score }= \\
\text { Total Relative Weights X } 10\end{array}$ & 180 & & \\
\hline \multicolumn{3}{|c|}{ Score Ratio $=$ Total Weighted Score $/$ Total Possible Score $=$} & $\mathbf{0 . 8 3 3}$ \\
\hline
\end{tabular}




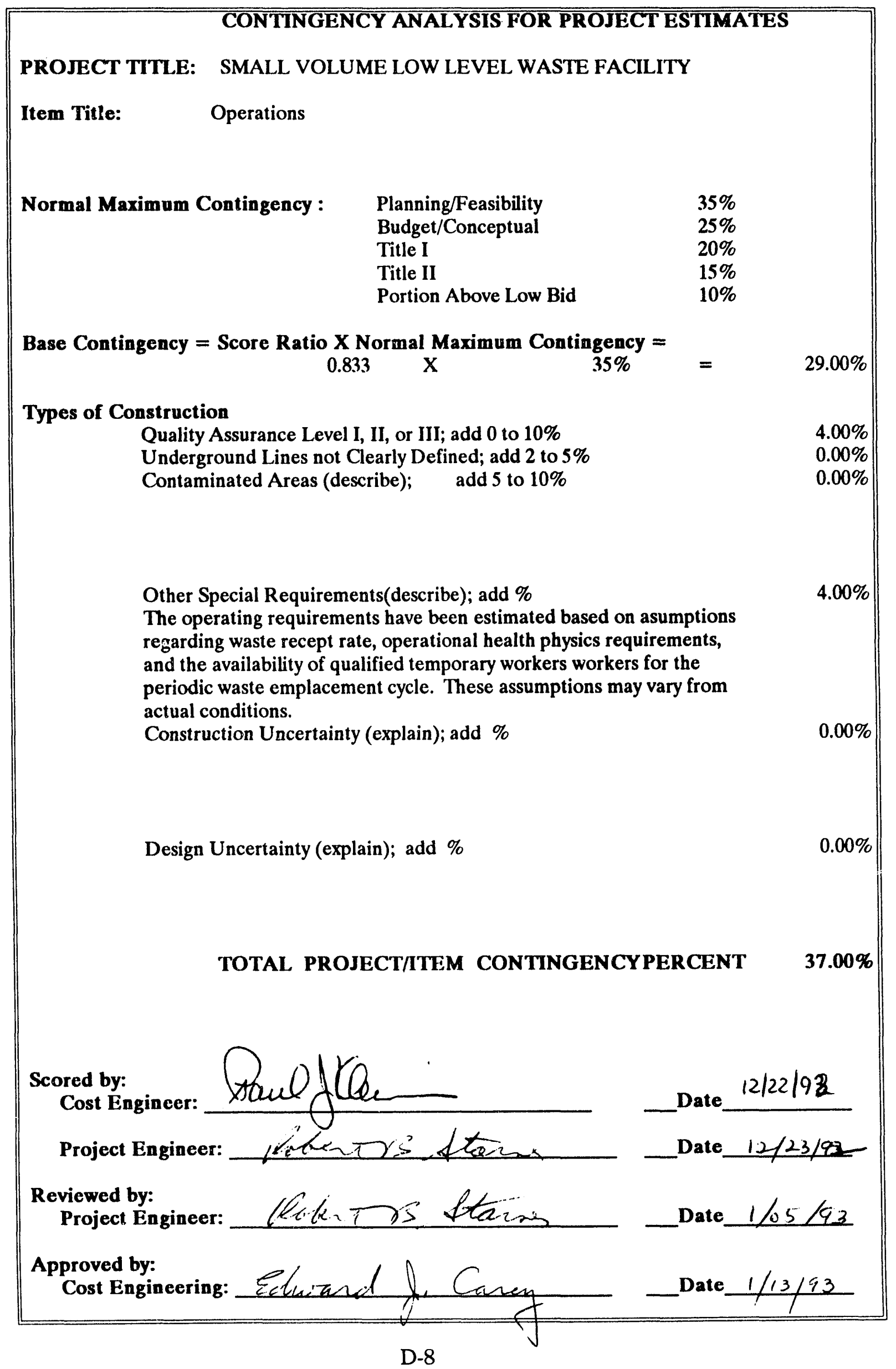




\begin{tabular}{|c|c|c|c|}
\hline $\begin{array}{l}\text { CONTINGENC } \\
\text { PROJECT TITLE: SMALL VO } \\
\text { Item Title: }\end{array}$ & $\begin{array}{l}\text { YYSIS FOR PROJ } \\
\text { OW LEVEL WAS }\end{array}$ & $\begin{array}{l}\text { ECT ESTIMATE } \\
\text { TE FACILITY }\end{array}$ & \\
\hline & $\begin{array}{l}\text { Relative } \\
\text { Weight } \\
0 \text { to } 10 \\
0=\text { N/A } \\
10=\text { Important }\end{array}$ & $\begin{array}{l}\text { Probability } \\
\text { Score } \\
1 \text { to } 10 \\
0=\text { Low Risk } \\
10=\text { High Risk }\end{array}$ & $\begin{array}{l}\text { Weighted } \\
\text { Score }\end{array}$ \\
\hline $\begin{array}{l}\text { Engineering Design \& Inspect. } \\
\text { Design Completeness } \\
\text { Site Selection/Conditions } \\
\text { Design Complexity } \\
\text { Specification Complexity } \\
\text { Design Schedule } \\
\text { Life Safety/Security }\end{array}$ & $\begin{array}{l}0 \\
0 \\
0 \\
0 \\
0 \\
0\end{array}$ & $\begin{array}{l}0 \\
0 \\
0 \\
0 \\
0 \\
0\end{array}$ & $\begin{array}{l}0 \\
0 \\
0 \\
0 \\
0 \\
0\end{array}$ \\
\hline $\begin{array}{l}\text { Construction } \\
\text { Types of Construction } \\
\text { Construction Complexity } \\
\text { Design Completeness } \\
\text { Market Conditions } \\
\text { Method of Accomplishment }\end{array}$ & $\begin{array}{l}9 \\
5 \\
8 \\
5 \\
5\end{array}$ & $\begin{array}{r}7 \\
7 \\
10 \\
5 \\
5\end{array}$ & $\begin{array}{l}63 \\
35 \\
80 \\
25 \\
25\end{array}$ \\
\hline $\begin{array}{l}\text { Special Facilities Equipment } \\
\text { Requestor's Specifications } \\
\text { Maturity of Technology } \\
\text { Design Completeness } \\
\text { Method of Accomplishment }\end{array}$ & $\begin{array}{l}0 \\
0 \\
0 \\
0\end{array}$ & $\begin{array}{l}0 \\
0 \\
0 \\
0\end{array}$ & $\begin{array}{l}0 \\
0 \\
0 \\
0\end{array}$ \\
\hline $\begin{array}{l}\text { Standard Equipment } \\
\text { Specification Completeness } \\
\text { Quantity Accuracy } \\
\text { Price Accuracy } \\
\text { Method of Accomplishment }\end{array}$ & $\begin{array}{l}0 \\
0 \\
0 \\
0\end{array}$ & $\begin{array}{l}0 \\
0 \\
0 \\
0\end{array}$ & $\begin{array}{l}0 \\
0 \\
0 \\
0\end{array}$ \\
\hline $\begin{array}{l}\text { Operations } \\
\text { Complexity } \\
\text { Schedule } \\
\text { Quality Assurance/Control }\end{array}$ & $\begin{array}{l}6 \\
6 \\
6\end{array}$ & $\begin{array}{l}9 \\
8 \\
8\end{array}$ & $\begin{array}{r}54 \\
48 \\
0\end{array}$ \\
\hline TOTALS & 50 & 59 & 330 \\
\hline $\begin{array}{l}\text { Total Possible Score }= \\
\text { Total Relative Weights X } 10\end{array}$ & 500 & & \\
\hline Score Ratio = Total Weighte & Total Possible & re $=$ & 0.660 \\
\hline
\end{tabular}




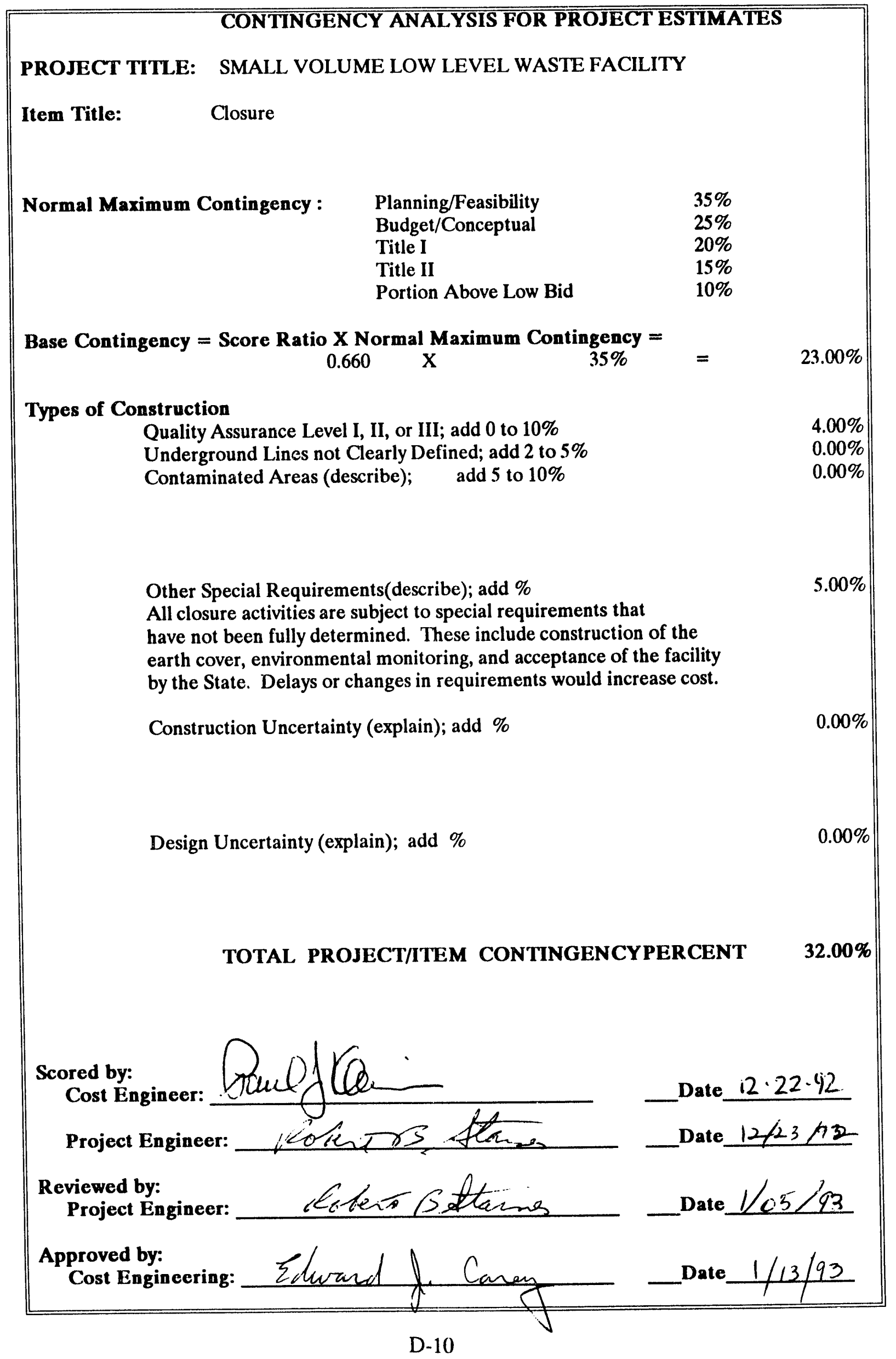




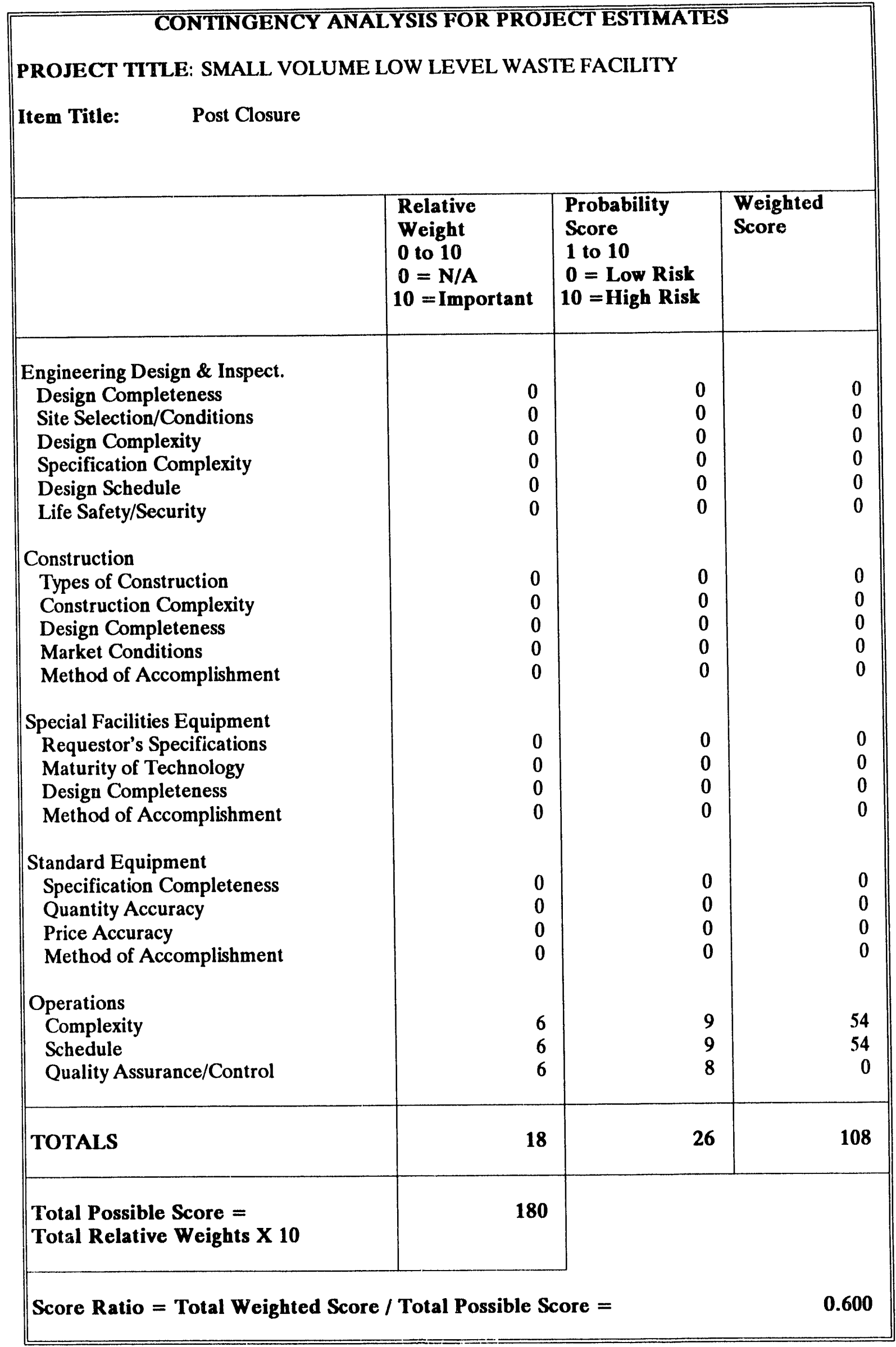




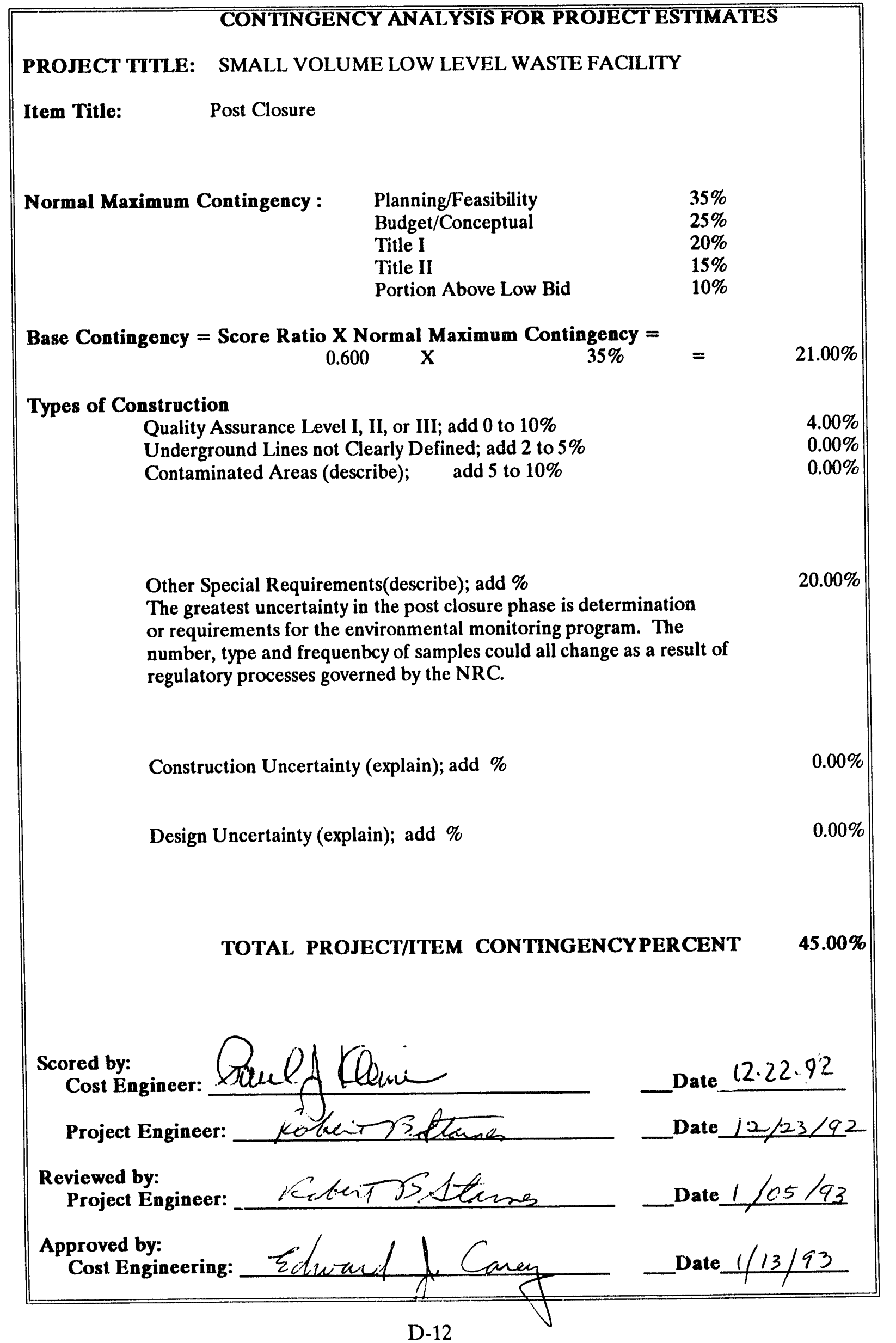




\section{Appendix E}

\section{Cost Data}


E-2 


\section{Appendix E}

\section{Cost Data}

The cost data that follows is presented in a code of accounts format specified by the National Low-Level Radioactive Waste Management Program. Contingency percentages are as calculated in Appendix D. Supporting calculations and assumptions are noted in the Base Cost Notes section of the worksheets. 
E-4 


\begin{tabular}{|c|c|c|c|c|c|}
\hline \multicolumn{6}{|c|}{ CODB OP ACCOUNTS SUMTARY WORKSHERT } \\
\hline DESCRIPTION & $\begin{array}{l}\text { BAss } \\
\text { Cost }\end{array}$ & Contina & 5 & TOTALS & BASE COST NOTES \\
\hline \multicolumn{6}{|l|}{ PRB OPERATUNG COSTS } \\
\hline Site Selection & $5,500,000$ & $1,870,000$ & $34 \%$ & $7,370,000 \mid \mathrm{C}$ & $\begin{array}{l}\text { Calculted within the analysis dose by office } 103 . \\
\text { (ref. Table 3-1) }\end{array}$ \\
\hline Site Data/Characterizatioa/EIS & $7,573,710$ & $2,575,061$ & $34 \%$ & $10,148,71$ & $\begin{array}{l}\text { Calcuhted within the analysis done by office } 103 \text {. } \\
\text { (ref. Table 4-3, Appendix A; includes one time initial enmpling and } \\
\text { gnma radiation grousd survey) }\end{array}$ \\
\hline Safety Analysis & 750,000 & 255,000 & $34 \%$ & $1,005,000$ & Calculated with in the anshysis dose by office 103 . \\
\hline Licensing & $4,000,000$ & $1,360,000$ & $34 \%$ & $5,360,000$ & Licensing includes Prepare/Submil/NRC Review. \\
\hline Fermits & 10,000 & 3,400 & $34 \%$ & 13,400 & Estimantor's allowanece. \\
\hline Administration & $2,947,000$ & $1,001,992$ & $34 \%$ & $3,948,989$ & $\begin{array}{l}\text { Calculated as } 98 \% \text { of Manogement Support labor. } \\
\text { (ret. Table } 4-2,4-5 \text { ) }\end{array}$ \\
\hline Construction Management & 301,144 & 102,389 & $34 \%$ & 403,533 & $\begin{array}{l}\text { Calcubited as 5\% (PM cont) of construction } \\
\text { cont of Support Buildings, Land Improvements. } \\
\text { and Utilities. } \\
\text { (ref. Table 4-1) }\end{array}$ \\
\hline General Supplies & 60,143 & 20,449 & $34 \%$ & 80,592 & Caiculated as $2 \%$ of Management Support labor. \\
\hline Lepal Fees & $1,000,000$ & 340,000 & $34 \%$ & $1,340,000$ & Calculated with in the amalysis dose by office 103 . \\
\hline Construction & $6,032,888$ & $2,051,182$ & $34 \%$ & $8,084,070$ & $\begin{array}{l}\text { Construction includes Support Buildings, Land } \\
\text { Improvements, UL.'.ities and Mobilization. } \\
\text { (ref. Table 4-1) }\end{array}$ \\
\hline Construction Equipment & 0 & 0 & $0 \%$ & 0 & Contractor Furnisibed \\
\hline Equipr $\approx n t$ Maintenance & 0 & 0 & $0 \%$ & 0 & Contractor Espense \\
\hline Engineering and Design & $2,030,003$ & 690,201 & $34 x$ & $2,720,201$ & $\begin{array}{l}\text { Calcubled as a percentage of Pre Ops construction, } \\
\text { disposal unit construction and construction equipmeat, } \\
\text { all of Operations and Post Closure. }\end{array}$ \\
\hline Operating Plan and Processes & $1,200,000$ & 408,000 & $34 \%$ & $1,608,000$ & Calculated with in the analysis done by office 103. \\
\hline Baseline Monitoring & $1,334,614$ & 453,769 & $34 \%$ & $1,788,383$ & (ref. Table 4-i) \\
\hline Instiutioual Transfer Payment & 0 & 0 & $0 \%$ & 0 & \\
\hline SUBTOTAL & $32,739,510$ & $11,131,433$ & $34 \%$ & $43,870,913$ & \\
\hline
\end{tabular}




\begin{tabular}{|c|c|c|c|c|c|}
\hline \multicolumn{6}{|c|}{ CODB OP ACCOUNTS SUMMARY WORKSHEET } \\
\hline DESCRIPTION & $\begin{array}{l}\text { BASE } \\
\text { COST }\end{array}$ & CONTING & $\%$ & TOTALS & BASE COST NOTES \\
\hline \multicolumn{6}{|l|}{ OPERATING CosTS } \\
\hline Facilities Startup & 161,926 & 59,913 & $37 \%$ & 221,839 & Calculated as subsequent years' Facilities Ma intenanoe costs. \\
\hline Disposel Unit Construction & $8,906,583$ & $3,295,436$ & $37 \%$ & $12,202,019$ & 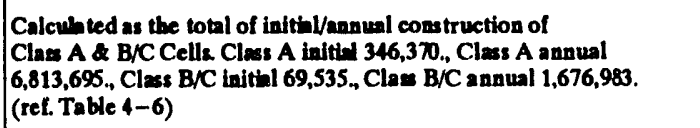 \\
\hline Construction Management & 445,329 & 164,772 & $37 \%$ & 610,101 & Calcubted as $5 \%$ of total cell construction cost \\
\hline Equipment Maintena nce & $4,185,308$ & $1,548,564$ & $37 \%$ & $5,733,873$ & $\begin{array}{l}\text { Calculated as lat year Eq. Maint cost 139,643. + 2nd year Eq. Maint. } \\
\text { cost } 139,506 \times 29 \text { years }=4,045,666+139,643=4,185,309 . \\
\text { (ref. Table } 4-10)\end{array}$ \\
\hline Buildiag \& Facilities Maint. & $3,393,924$ & $1,255,752$ & $37 \%$ & $4,649,676$ & $\begin{array}{l}\text { Calcubted as } 95.5 \% \text { of lst year cost } 118,462 . \times 30 \text { yearn. } \\
\text { (ref. Table 4-5) }\end{array}$ \\
\hline Payrol & 0 & 0 & $0 \%$ & 0 & \\
\hline Corporate Administration & 0 & 0 & $0 \%$ & 0 & \\
\hline Legal Fees & 402,672 & 148,989 & $37 \%$ & 551,660 & Calculated as $1 \%$ of total Site Ops cost $(40,267,183)$. \\
\hline Environmental Monitoring & $22,687,080$ & $8,394,220$ & $37 \%$ & $31,081.300$ & $\begin{array}{l}\text { Calculated as } 756,236 \text { per year } \times 30 \text { yeans } \\
\text { (ref. Table 4-11) }\end{array}$ \\
\hline Regulatory Costs & 0 & 0 & $0 \%$ & 0 & \\
\hline Consumable & 805,344 & 297,977 & $37 \%$ & $1,103,321$ & Calcubted as 2\% of total Site Ope cost $(40,267,183$.) \\
\hline Office Equipment & 604.008 & 223,483 & $37 \%$ & 827,491 & Calculated as $1.5 \%$ of total Site Ops $\cos t(40,267,183$. \\
\hline Surety Bond & 0 & 0 & $0 \%$ & 0 & \\
\hline Institutional Transfer Paymeat & 0 & 0 & $0 \%$ & $\mathbf{0}$ & \\
\hline Construction Equipment & $5,790,000$ & $2,142,300$ & $37 \%$ & $7,932,300$ & $\begin{array}{l}\text { Calcubled as total of new equipment 1st year cost } 1,930,000 \text {. } \\
\text { and total replacemeat equipment costs during subsequent years } \\
3,860,000 \text {. } \\
\text { (ref. Table 4-10) }\end{array}$ \\
\hline Sile Operations & $35,061,235$ & $12,972,657$ & $37 \%$ & $48,033,892$ & $\begin{array}{l}\text { Calcuhted as 95.5\% of total Site Ope cost less Bidg and Fac. Maint. } \\
(38,455,159 .-3,393,924 .=35,061,235 \text {.) (ref. Tabtes } 4-7,4-2)\end{array}$ \\
\hline Waste Operations & $2,808,000$ & $1,038,960$ & $37 \%$ & $3,846,960$ & $\begin{array}{l}\text { Calculated withis TL as total per year cost } 93,600 \times 30 \text { years } \\
\text { (ref. Tables } 4-9,4-2 \text { ) }\end{array}$ \\
\hline SUBTOTAL. & $85,251,409$ & $31,543,021$ & $37 \%$ & $116,794,431$ & \\
\hline
\end{tabular}




\begin{tabular}{|c|c|c|c|c|c|}
\hline \multicolumn{6}{|c|}{ CODE OP ACCOUNTS SUMMARY WORKSHEET } \\
\hline DESCRIFTION & $\begin{array}{l}\text { BASB } \\
\text { COST }\end{array}$ & ConTria & 5 & TOTALS & BASE COST NOTES \\
\hline \multicolumn{6}{|l|}{ CLOSURE COSTS } \\
\hline Disposal Unit Closure (Earth Berm) & $1,948,746$ & 623,599 & $32 \%$ & $2,572,345$ & $\begin{array}{l}\text { Calcubated within CP as tc tal cost of Earth Berm } \\
\text { (ref. Table 4-12) }\end{array}$ \\
\hline Engineering and Design & 295,524 & 94,568 & $32 \%$ & 390,092 & Calculated as $10 \%$ of total Earth Berm and Bldz. D\&D costs. \\
\hline Construction Management & 147,762 & 47,284 & $32 \%$ & 195,046 & Calculated as $5 \%$ of total Earth Berm and Bidg. D\&D costs. \\
\hline Personnel & $3,174,900$ & $1,015,968$ & $32 \%$ & $4,190,868$ & $\begin{array}{l}\text { Calculated within Th as total labor costs for Closure. } \\
\text { (ref. Table } 4-13,4-2 \text { ) }\end{array}$ \\
\hline Building/Facility Maintenance & 572,175 & 183,096 & $32 \%$ & 755,270 & Calcubted as monthly $\cos t 10,038 . \times 5$ years. \\
\hline Construction Equipment & 128,000 & 40,960 & $32 \%$ & 168,960 & $\begin{array}{l}\text { Incluckes purchase of new 4-door sedan, 4WD pickup, and backboe. } \\
(15,000+15,000+98,000=128,000) \text { (ref. Table } 4-10)\end{array}$ \\
\hline Equipment Maintenance & 674,481 & 215,834 & $32 \%$ & 890,315 & Calcubted as monthly cost $11,833$. x 5 years. (ref. Table 4-10) \\
\hline Environmental Monitoring & $3,777,530$ & $1,208,810$ & $32 \%$ & $4.986,340$ & $\begin{array}{l}\text { Calculated as yearly } \cos t 756,236 . \times 5 \text { years, plus a final gamma radiation } \\
\text { ground survey. (ref. Table } 4-11 \text { ) }\end{array}$ \\
\hline Fuel, Utilities and Materials & 680,394 & 217,726 & $32 \%$ & 898,120 & \\
\hline Instiutional Transfer Payments & 0 & 0 & $0 \%$ & 0 & \\
\hline Regulatory Costs & 0 & 0 & $0 \%$ & 0 & \\
\hline Building/Facility D\&D & $1,050,140$ & 336,048 & $32 \%$ & $1,386,197$ & $\begin{array}{l}\text { Calculated with in Costpro as the total for decontamination and demolition } \\
\text { of unnecessary structures on the site. }\end{array}$ \\
\hline SUBTOTAL & $12,449,651$ & $3,933,891$ & $32 \%$ & $16,433,552$ & \\
\hline
\end{tabular}




\begin{tabular}{|c|c|c|c|c|c|}
\hline \multicolumn{6}{|c|}{ CODE OP AOCOUNTS SUMRARY WORKAHEET } \\
\hline DESCRIPTTON & $\begin{array}{l}\text { BASB } \\
\text { COST }\end{array}$ & CONTING & $\overline{5}$ & TOTAS & BASE COST NOTES \\
\hline \multicolumn{6}{|l|}{ POST CLOSURB COSTS } \\
\hline Perwonnel & $17,880,000$ & $8,046,000$ & $45 \%$ & $25,926,000$ & (ref. Table 4-15, 4-2) \\
\hline Construction Equipment & 790,000 & 355,500 & 45\% & $1,145,500$ & $\begin{array}{l}\text { Iacludes purchase of a new 4-door sedan and 4WD pickup evry } 10 \text { years } \\
\text { and a new backboe every } 20 \text { yearn. (ref. Table 4-10) }\end{array}$ \\
\hline Fuel, Utilities and Materials & 0 & 0 & $45 \%$ & 0 & \\
\hline Environmental Monitoring & $7,596,000$ & $3,418,200$ & $45 \%$ & $11,014,200$ & $\begin{array}{l}\text { Calculhted as total of Post Closure Env. Mont. costs as shown in Table 4-16 } \\
\text { (ref. Table 4-16) }\end{array}$ \\
\hline Equipment \& Vehicle Maint. & $1,450,000$ & 652,500 & $45 \%$ & $2,102,500$ & $\begin{array}{l}\text { Calcubled within CP as total cost per year 14,500. } \times 100 \text { yean } \\
\text { (ref. Table 4-10) }\end{array}$ \\
\hline Administration & 0 & 0 & $0 \%$ & 0 & \\
\hline Regulatory Costs & 0 & 0 & $0 \%$ & 0 & \\
\hline SUBTOTAL & $27,716,000$ & $12,472,200$ & 45\% & $40,188,200$ & \\
\hline GRANDTOTAL & & & & $217,287,126$ & \\
\hline
\end{tabular}



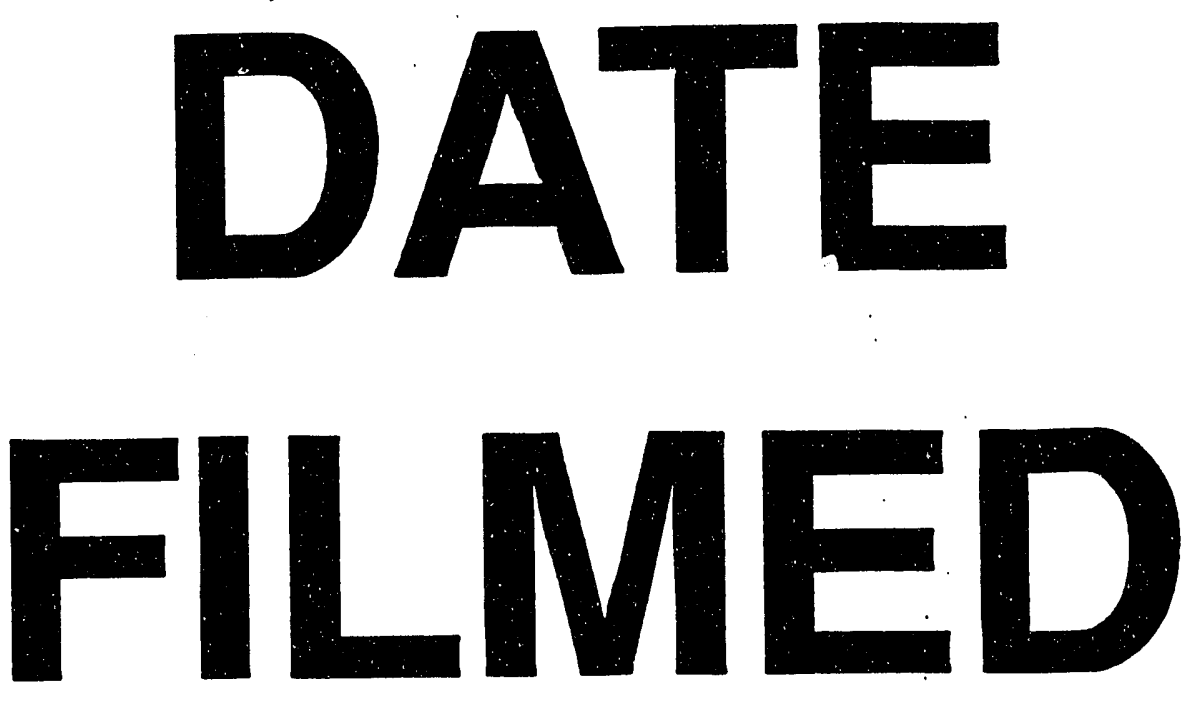

$9 / 27 / 93$
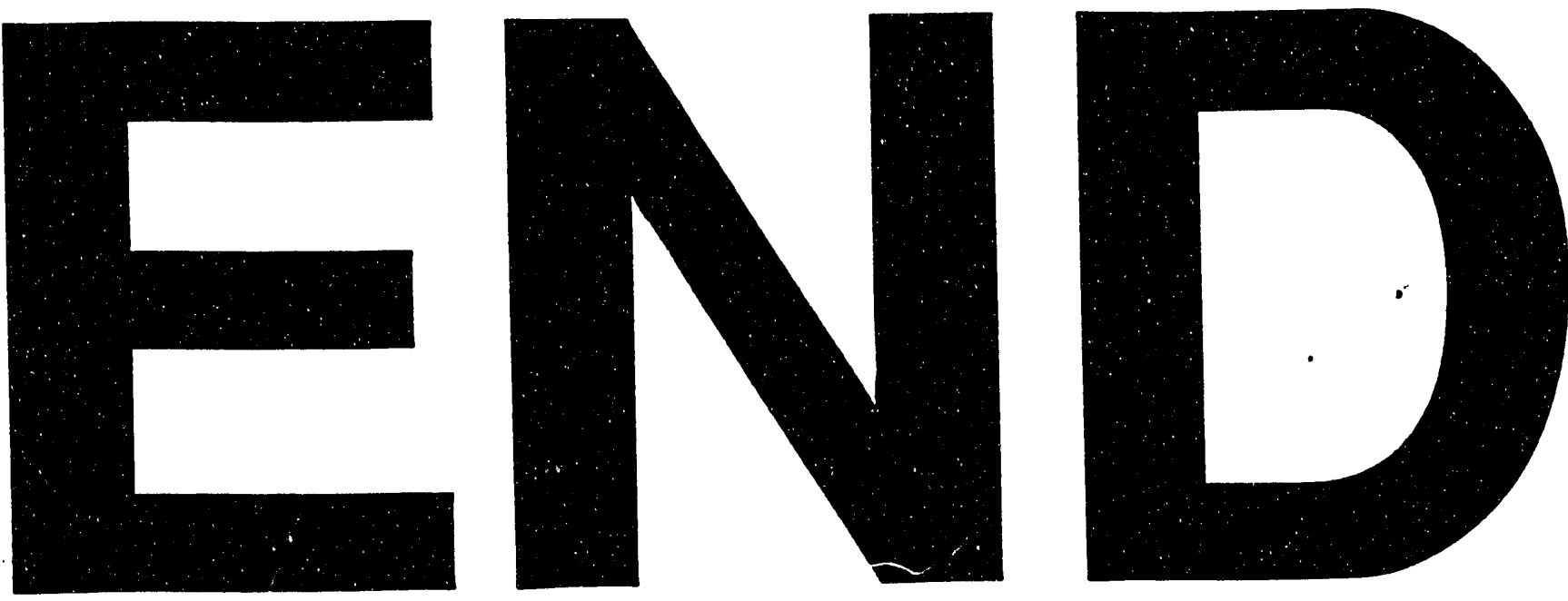
